\title{
Development of lipid biomarker based diagnostic method for TB research in archaeological samples via HPLC-HRMS
}

Ph.D. dissertation

Orsolya Anna Váradi

Supervisors:

Dr. habil György Pálfi, associate professor, head of department Dr. András Szekeres, senior research fellow

Doctoral School of Biology

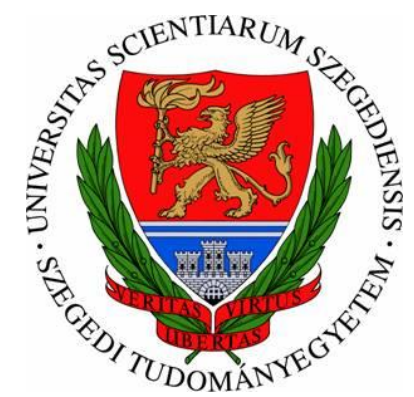

Department of Biological Anthropology and Department of Microbiology

Faculty of Science and Informatics

University of Szeged 
"I believe that anyone who claims to know what's going on will lie about the little things too."

Neil Gaiman: American Gods

In memory of those who are gone but always with me. 


\section{TABLE OF CONTENTS}

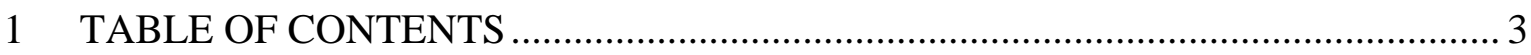

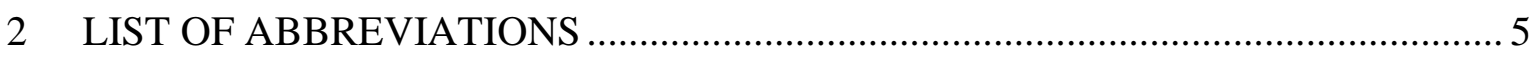

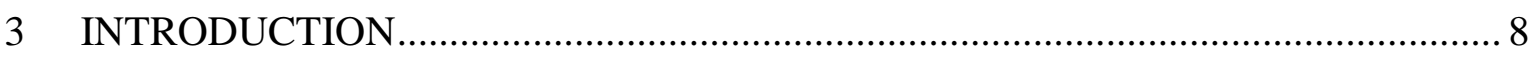

3.1 A brief overview of the history of tuberculosis ................................................ 8

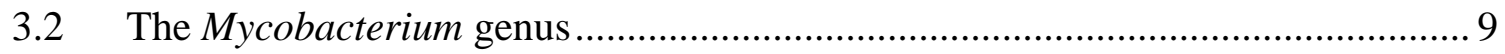

3.3 Clinical significance of the some of the NTM species .................................... 10

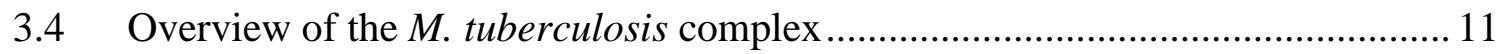

3.5 Phylogenetic relationships within the $M$. tuberculosis complex ......................... 14

3.5.1 Phylogeny of human-adapted MTBC members ...................................... 14

3.5.2 Phylogeny of animal-adapted MTBC members ..................................... 15

3.5.3 The most common hypothesis regarding the origin of MTBC members ...... 16

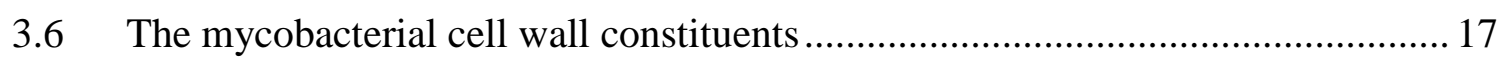

3.7 The main steps in the pathogenesis in the establishment of tuberculosis ............. 21

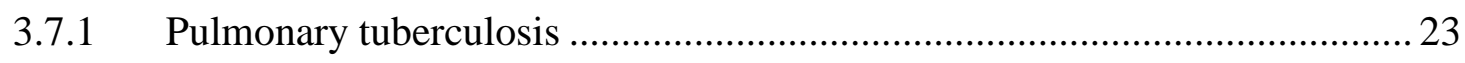

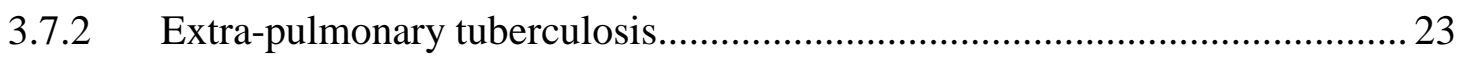

3.8 Molecular biological and analytical methods in the use of ancient TB detection 28

3.8.1 The development of aDNA techniques for TB diagnosis............................ 28

3.8.2 The development of lipid biomarker based techniques for TB diagnosis ..... 29

3.8.3 Examples of the combined macroscopic, aDNA and lipid biomarker based

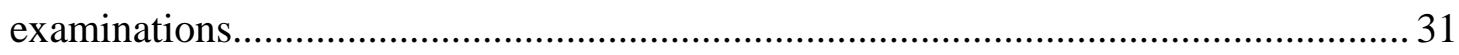

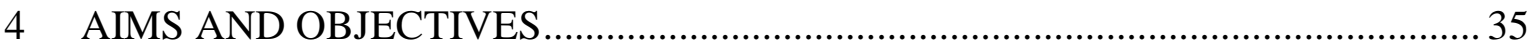

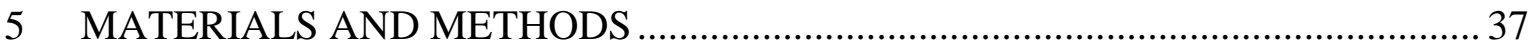

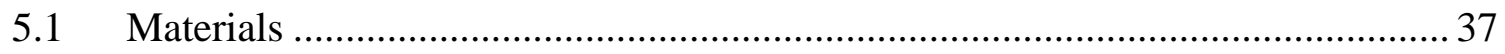

5.1.1 The used bacterial and human samples .................................................. 37

5.1.2 Historical samples used for testing the developed mycocerosic acid detection method 37 
5.1.3 Solvents, chemicals and consumables and equipments used for measurements 38

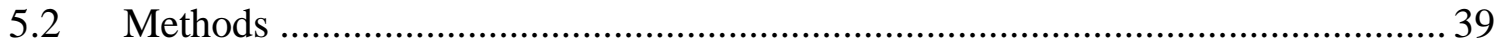

5.2.1 Optimisation of the mycolic acid detection method .................................... 39

5.2.2 Mycocerosic acid separation and detection by Q-Exactive Plus Orbitrap MS 43

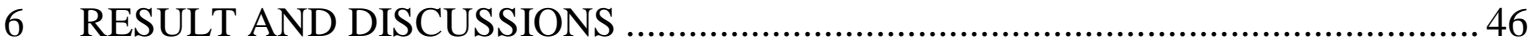

6.1 Optimisation of the mycolic acid detection method .......................................... 46

6.1.1 Mycolic acid detection by single quadrupole LCMS ................................... 46

6.1.2 Mycolic acid detection by Q-Exactive Plus Orbitrap MS ........................... 49

6.1.3 Mycocerosic acid separation and detection by Q-Exactive Plus Orbitrap MS 66

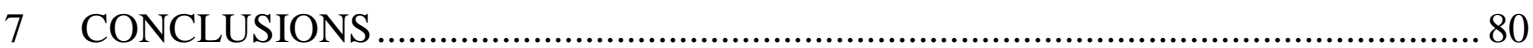

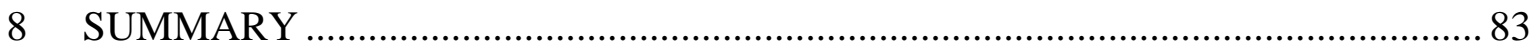

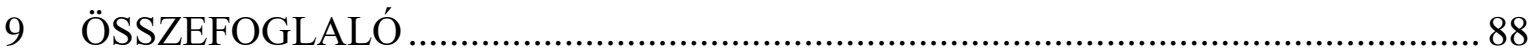

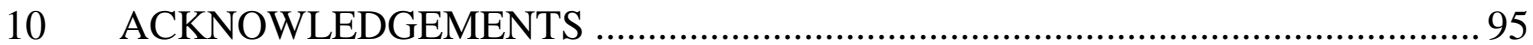

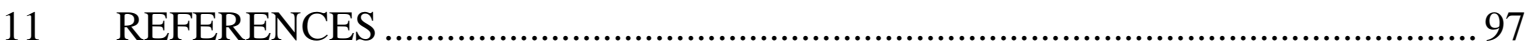

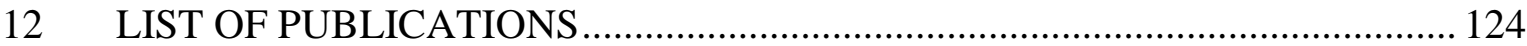




\section{LIST OF ABBREVIATIONS}

ABVI abnormal blood vessel impression

ACN acetonitrile

$\mathrm{AcOH} \quad$ acetic acid

AG arabinogalactane

APDI abnormally pronounced digital impression

CDL curved desolvation line

CNS central nervous system

CW cell wall

DAT diacyl trehalose

DFBP decafluorobenzophenone

ECD electron capture detector

EIC extracted ion chromatogram

ESI electrospray ionisation

FA fatty acids

FIA flow injection analysis

FID flame ionisation

FLD fluorescence detector

GC gas chromatograph

GI granular impression

GMM glucose monomycolates

HIV immunodeficiency virus

HPLC high performance liquid chromatograph

HPO hypertrophic pulmonary osteoarthropathy

IPA isopropanol 


\begin{tabular}{|c|c|}
\hline LAM & lipoarabinomannan \\
\hline LM & lipomannan \\
\hline LOS & lipooligosaccharid \\
\hline LPSN & List of Prokaryotic names with Standing in Nomenclature \\
\hline MA & mycolic acid \\
\hline MAC & M. avium complex \\
\hline MAF/WAF & M. africanum type I, Western-African \\
\hline MC & mycocerosic acid \\
\hline MDR & multidrog-resistant \\
\hline $\mathrm{MeOH}$ & methanol \\
\hline ML & mycolipenic acid \\
\hline MMG & monomycolic glycerols \\
\hline MPA & molybdophosphoric acid \\
\hline MRCA & most recent common ancestor \\
\hline MRM & multiple reaction \\
\hline MS & mass spectrometer \\
\hline MTB & Mycobacterium tuberculosis \\
\hline MTBC & Mycobacterium tuberculosis complex \\
\hline MTBE & methyl tert-butyl ether \\
\hline NI-CI & negative ion chemical ionisation \\
\hline NP & normal phase \\
\hline NTM & non-tuberculous mycobacteria \\
\hline PA & periosteal apposition \\
\hline PAT & pentaacyl trehalose \\
\hline
\end{tabular}




\begin{tabular}{|c|c|}
\hline PBA & pyrenebutyric acid \\
\hline PDIM & phthiocerol dimycocerosate \\
\hline PFB & pentafluorobenzyl bromide \\
\hline PG & peptidoglycan \\
\hline PGL & phenolic glycolipids \\
\hline PIM & phosphatidylinositol mannosides \\
\hline PNFB & periosteal new bone formation \\
\hline PRM & parallel reaction monitoring \\
\hline PTFE & polytetrafluoroethylene \\
\hline RD & region of difference \\
\hline $\mathrm{RP}$ & reverse phase \\
\hline SGL & sulphated trehalose glycolipid \\
\hline SIM & selected ion monitoring \\
\hline SNP & single nucleotide polymorphism \\
\hline SPE & solid phase extraction \\
\hline STB & smooth tubercle bacillus \\
\hline TB & Tuberculosis \\
\hline TBM & tuberculous meningitis \\
\hline TDM & trehalose dimycolate \\
\hline TLC & thin layer chromatography \\
\hline TLR & Toll-like receptors \\
\hline TMM & trehalose monomycolate \\
\hline TSA & tuberculostearic acid \\
\hline XDR & extensively drug-resistant \\
\hline
\end{tabular}




\section{INTRODUCTION}

\subsection{A brief overview of the history of tuberculosis}

Tuberculosis (TB) is not only an infectious disease, but one of the top 10 causes of death, spreading mainly with aerosol transmission (WHO, 2020). This devastating plague has been accompanying the history of humankind for several millennia (Gutierrez et al., 2005; Daniel, 2006; Baker et al., 2015; Barberies, et al., 2017). Early proofs of the recognition of the disease can be found among ancient Egyptian artworks dated to $3000 \mathrm{BC}$, moreover morphological and aDNA investigations seems to support the existence of this plague in the era (Zink et al., 2003). The first written records of the disease are known from China and India (Cave, 1939; Brown, 1941; Robert \& Buikstra, 2003; Daniel, 2006; Barberies et al., 2017). Written notes of the disease can be found also in the Bible referring to TB with the name "schachepheth" (Daniel \& Daniel 1999; Daniel, 2006; Barberies, et al., 2017). TB was well known in the ancient Greece also, Hippocrates called it "phthsis" in Book I, of the Epidemics (Daniel, 2006; Barberies, et al., 2017). However, the written sources related to TB are sporadic from the middle ages, the scrofula or "King's evil", as a new clinical form of TB with extra-pulmonary nature, was spreading across Europe in this period (Daniel, 2006; Barberies et al., 2017; Murray, et al., 2016). Despite of the fact that TB was observed for such a long time, and known on many names, the first clear explanation of the pathogenesis and an unified concept of both pulmonary and extra-pulmonary TB was not described until 1819, when Laennec released his book D'Auscultation Mediate (Duffin, 1998; Daniel, 2004; Daniel, 2006; Barberies, et al., 2017). The first TB sanatorium was established in Görbersdorf, 1859 (Daniel, 2006; Barberies, et al., 2017). The infectious nature of TB has been proven not long after, in 1865, by Jean-Antoine Villemin. On March 24th, 1882 Robert Koch presented his results of identifying the infectious agent of tuberculosis, which is also known as Koch-bacillus since then. Nowadays this date is commemorated as the world tuberculosis day (Daniel, 2006; WHO, 2020). In the 18th-19th century tuberculosis was epidemic in Europe implying an extraordinary burden, especially after the middle of the 18th century, as the industrial revolution, poverty, urbanisation and squalor created an excellent reservoir for the spread of TB (Bello et al., 1999; Vuorinen, 1999, Glaziou et al., 2018; Loddenkemper et al., 2018; Roberts, 2020). At the beginning of the 18 th century $10 \%$ of all death cases were TB-related, but by the end of the century it reached up to $25 \%$ of all death in London (Roberts, 2020). Although, these data should be 
handled with great care, as the records were taken by not educated people and at least four names related or not to TB was used at this time. These names are: consumption, King's Evil, fever and tissick, what referred to different lung diseases, however in other countries similar trends were observed (Bello et al., 1999; Vuorinen, 1999). Several scientific achievements followed Koch's discovery in the next decades, such as the tuberculin skin test of Pirquet and Mantoux, the development of the BCG vaccine by Albert Calmette and Camille Guérin, and the insolation of streptomycin the first anti-tuberculotic drug by Albert Schatz, Elizabeth Bugie and Selman Waksman (Daniel, 2006; Barberies et al., 2017). Despite of all these and the followed efforts TB is still a relevant worldwide burden (Robert \& Buikstra, 2003; Gutierrez et al., 2005; Roberts 2020; WHO, 2020;).

\subsection{The Mycobacterium genus}

Mycobacterium is a monophyletic group and it is the only genus of the family Mycobacteriaceae within the Actinomycetales order including more than 200 species according to the LPSN list (Nouioui et al., 2018; Turenne, 2019; http://www.bacterio.net/ mycobacterium.html). Mycobacteria are acid-fast aerobic bacilli, including the members of M. tuberculosis complex, M. leprae, and non-tuberculous mycobacteria (NTM) (Turenne, 2019; van Ingen et al., 2018). For the identification of mycobacteria on the species level, $16 \mathrm{~S}$ rRNA gene sequencing is widely used, however, in some cases the usage of alternate target is also needed, such as certain housekeeping genes (Tortoli, 2014; CLSI, 2018; Nouioui et al., 2018; Turenne, 2019).

The Mycobacterium leprae is the causative agent of leprosy or Hansen's disease, however, the disease in less common cases are caused by its sister taxon, M. lepromatosis. M. leprae is an obligate intracellular human pathogen (Serrano-Coll et al., 2018; Blevins et al., 2020; Borah et al., 2020). In contrast with M. tuberculosis, M. leprae replicates mainly in Schwann cells and endothelial cells (Serrano-Coll et al., 2018; Borah et al., 2020). Leprosy can manifest as both disseminated infection and localized infection (Borah et al., 2020). The characteristic disease caused by this infectious agent is damaging the skin and the peripheral nerve trunk (Serrano-Coll et al., 2018).

NTM species can be primarily found in soil and water, however some of them are opportunistic pathogens, causing infections in humans (e.g. M. kansasii) and animals (e.g. M. senegalense), but they are not presenting in human-to-human transmissions (Turenne, 2019). 


\subsection{Clinical significance of the some of the NTM species}

Mycobacterium kansasii is a slow growing, highly virulent Mycobacterium species, which can be isolated mainly from tap water (Johnston et al., 2017; Bakuła et al., 2018). This opportunistic pathogen is causing apical fibro-cavitary lung disease (Bakuła et al., 2018; Huang et al., 2020). The caused symptoms and observed histopathology, and images are similar to those of tuberculosis, however it requires different drug-treatment, which implies the need of fast and prompt identification (Huang et al., 2020).

Mycobacterium chelonae is a rapidly growing NTM species, which can be isolated from natural and tap water, soil and aquatic animals (Akram \& Saleh, 2020). In the case of human infection $M$. chelonae usually invades the host through an entering site opened due to traumas or human interventions on the skin, such as surgery, resulting a localized skin infection in immunocompetent patients, however dissemination can occur in immunocompromised individuals (Daley \& Griffith, 2010; Akram \& Saleh, 2020).

Mycobacterium gordonae is a slow growing NTM species, which is primarily isolated from water and soil (Chen et al., 2017; Chang et al., 2020). It is traditionally considered to have only a weak pathogenicity, however infections in both immunocompetent and immunocompromised individuals have been reported.

Mycobacterium avium complex (MAC) includes 12 slow growing Mycobacterial species, such as M. avium and M. intracellulare, M. chimaera with the predominance of the former two, which are responsible for most of the NTM caused lung diseases (Koh et al., 2017; van Ingen et al., 2018; Busatto et al., 2019). MAC is an opportunistic human pathogen group with an emerging clinical concern. Beside lung disease, they can cause for example cervical lymphadenitis and disseminated infection, mainly affecting immunocompromised individuals.

Mycobacterium abscessus is a rapidly growing Mycobacteria, which can be isolated from soil, water and tap water (Mougari et al., 2016; Meir et al., 2017; Osmani et al., 2018). This opportunistic pathogen can affect the lungs (most often in individuals already having pulmonary disease), the soft tissue and skin, central nervous system (CNS), and has the ability to disseminate. The main concerns regarding M. abscessus is that it is mainly infecting immunocompromised patients, and being resistant for eradication.

Mycobacterium fortuitum complex includes rapidly growing Mycobacteria, which can be found mainly in soil and water (Okamori et al., 2018; Erber et al., 2020). It has been reported 
to cause pulmonary disease in patients with underlying lung disease, however in case of human infection it mainly manifests as skin and bone/joint infection (Gracia-Cazaña et al., 2017; Okamori et al., 2018; Erber et al., 2020). Several cases were reported, wherein the infection was the result of human interventions, opening infection site on the skin (GraciaCazaña et al., 2017; Erber et al., 2020).

\subsection{Overview of the $M$. tuberculosis complex}

Tuberculosis can be caused by the members of Mycobacterium tuberculosis complex (MTBC). The members of this group can cause illness in humans as well as in several animal species (Brites et al., 2018). The complex includes so far 12 genetically closely related species/varieties with 99.9\% similarity in nucleotide level (Brosch et al., 2002; Brites \& Gagneux, 2017; Brites et al., 2018; Riojas, et al., 2018). The 12 members are the following: M. tuberculosis, M. africanum, "M. canettii", M. bovis, M. microti, M. pinnipedii, M. orygis, M. mungi, M. suricattae, M. caprae, "chimpanzee bacillus", "dassie bacillus" (Brites et al., 2018; Riojas et al., 2018). The first three species are specifically human pathogens (Castets et al., 1968; Brosch et al., 2002; Niemann et al., 2004; Bañuls et al., 2015).

Myobacterium tuberculosis (MTB) led to the death of approximately 1.2 million people, who were not infected with human immunodeficiency virus (HIV), and further 208000 HIVpositive people died in MTB infection and approximately 10 million people fell ill with TB globally in 2019. The most affected regions are South-East Asia, Africa and the Western Pacific (Figure 1) (WHO, 2020).

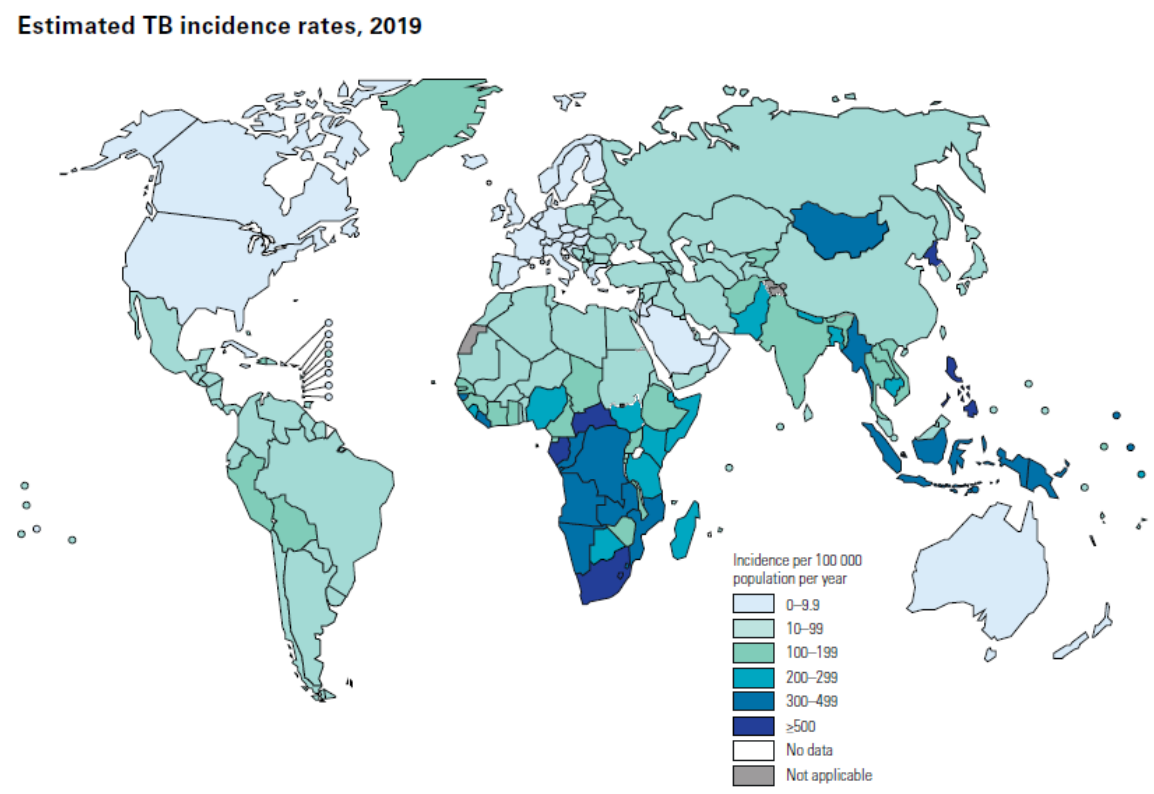

Figure 1: The estimated TB incidence rates in 2019 according to WHO (WHO, 2020) 
Although M. tuberculosis is responsible for most of the TB infection cases (Bañuls et al., 2015), Mycobacterium africanum is the causative agent of half of the human TB cases in West Africa (de Jong et al., 2010a). M. africanum can be divided into two subgroups (Niemann et al., 2004). Subgroup I is more prevalent in the Western African region, while subgroup II is mostly spread in the Eastern African region, also reclassified as the part of $M$. tuberculosis sensu stricto (de Jong et al., 2010a; de Jong et al., 2010b; Nimeann et al., 2004). The latter group is also known as "Uganda" genotype (de Jong et al., 2010a). Within the Western African subgroup two clusters can be divided: MAF1 (or WAF1), and MAF2 (or WAF2) (de Jong et al., 2010a; Parsons et al., 2019). The first group is presenting a deletion in Region of Difference (RD) 9, the second group beside the deletion of RD9 has further deletions in RD7, RD8, RD10.

"Mycobacterium canettii", also known as "smooth tubercle bacillus" (STB) - referring to its unusual colony morphology - is isolated mainly in East Africa (Koeck et al., 2011; Supply \& Brosch, 2017). "M. canettii" is primarily causing opportunistic infections in humans (Koeck et al., 2011; Brites et al., 2018). Based on genetic similarities and also on the fact that " $M$. canettii" is capable to cause TB, it is traditionally included in MTBC (Brosch et al., 2002; Osman et al., 2016; Bouzid et al., 2017; Brites et al., 2018), however, there is no consensus in this matter yet, many studies are noting it as a closely related species (Supply et al., 2013; Supply \& Brosch, 2017; Gagneux, 2018). To decide this question is not part of this dissertation, however " $M$. canettii" is crucial in the understanding of the evolutionary connections within MTBC, therefore this species is going to be discussed as an MTBC member in this dissertation.

Mycobacterium bovis is primarily infecting cattle, but it has a wide host range including humans, pets and wild animals (de la Rua-Domenech, 2006, Mandal et al., 2011; Allen, 2017; Gagneux, 2018). M. bovis is responsible for the $0.5-7.2 \%$ of human TB cases mainly as milk-borne disease, but other uncommon transmission routes have been already reported such as close contact with infected cattle, or transmission among immuno-competent people (Blázquez et al., 1997; de la Rua-Domenech, 2006; Brites et al., 2018).

Mycobacterium caprae was initially described as a subspecies of $M$. tuberculosis, isolated from goats (Aranaz et al., 1999), later it was also known as M. bovis subsp. caprae (Niemann et al., 2002), and in 2003 was elevated to an independent species status (Aranaz et al., 2003). Since the first isolation from goats, $M$. caprae infection cases have been diagnosed from a 
range of other mammals, such as cattle, sheep, boars, deer, wolves, captive elephant, rabbit and also humans, mainly in Europe (Cvetnik et al., 2007; Orłowska et al., 2017; Yoshida et al., 2018; Dorn-In et al., 2020; Reis et al., 2020; Sevilla et al., 2020).

Mycobacterium microti has been initially characterized as pathogen of small rodents, voles, but later a wider range of hosts has been recognized, including pets, livestock, boars and even humans (Cavanagh et al., 2002, Panteix et al., 2010; Pérez de Val et al., 2019). However, human TB infection caused by $M$. microti are considered rare, it can be observed even in immunocompetent individuals, in both pulmonary and extra-pulmonary forms (Panteix et al., 2010).

Mycobacterium pinnipedii was first described in the beginning of the $20^{\text {th }}$ century, but it was identified as a MTBC member only 90 years later (Roe et al., 2019). Its main hosts are pinnipeds, but has been also detected from other marine- and non-marine organisms (Kiers et al., 2008; Roe et al., 2019; Macedo et al., 2020). Human infection cases were also described, however, they are extremely rare and some of the reports might be questionable (Kiers et al., 2008; Zmak et al., 2019; Macedo et al., 2020).

Mycobacterium orygis, earlier known as "oryx bacilli", had been distinguished clearly from M. bovis in 2005 (Mostowy et al., 2005; Dawson et al., 2012), and was classified into the MTBC in 2012 (van Ingen et al., 2012). It can infect a wide range of animals including several species of antelopes, gazelles, cow, rhesus monkey as well as even rhinoceros and humans (Dawson et al., 2012; van Ingen et al., 2012; Thapa et al., 2016; Marcos et al., 2017). Although, TB cases in humans caused by $M$. orygis can be considered really rare, not only animal-to-human transmission was presented, but in one case a human-to-animal transmission route was already characterized (Dawson et al., 2012; van Ingen et al., 2012).

Mycobacterium mungi had been first discovered in Botswana, where it was infecting banded mongooses with a high mortality rate (Alexander et al., 2010). In contrast with other MTBC members the primary rout of transmission of this pathogen is not respiratory, but environmental (Alexander et al., 2010; 2016). Mongooses are using anal gland secretion and urine for communication and through this path $M$. mungi could spread among individuals. An other interesting difference of the disease appearing in mongooses is that the lesions can be observed in the lungs rather in advanced stage of the infection (Alexander et al., 2016). Other hosts than banded mongooses have not been discovered, yet (Alexander et al., 2018). 
A close "relative" of the aforementioned MTBC member, Mycobacterium suricatte was also discovered in South Africa, and also has a very narrow host range, so far it was detected only from meerkats (Parsons et al., 2013). TB caused by $M$. suricatte is a highly disseminated disease, affecting many organs (e.g. spleen, lungs, liver), however the most characteristic symptom is the swelling of the sub-mandibular lymph nodes (Clarke et al., 2016).

The "dassie bacillus" was first thought to be an attenuated strain of M. microti (Wagner et al., 1958), but shortly after, in 1960, it was described as an independent Mycobacterium, isolated from rock hyrax (Smith, 1960). Later studies proved that this bacillus is wide spread in South Africa (Parsons et al., 2008), and it was also reported from the Middle East, probably transferred via a hydrax captivated in South Africa (Cousins et al., 1994). These animals are living in close proximity with each other what is helping this bacillus to spread in the groups (Parsons et al., 2008).

The so-called "Chimpanzee Bacillus" has been cultivated from wild chimpanzee (Coscolla et al., 2013). However, TB had been described in case of captive chimpanzees earlier, with a more limited technique those were identified as M. africanum and M. tuberculosis infection, also close contact with human was present (Thorel, 1980; Michel et al., 2003).

\subsection{Phylogenetic relationships within the $M$. tuberculosis complex}

\subsubsection{Phylogeny of human-adapted MTBC members}

The human-adapted MTBC strains has been classified into eight lineages, which are geographically structured, based mainly on large sequence polymorphisms observed in 20 RDs and lineage specific single nucleotid polymorphisms (SNPs) (Gagneux et al., 2006; Firdessa et al., 2013; Tessema et al., 2013; Ngabonziza et al., 2020). "M. canettii” has an ancestral place on the evolutionary tree of MTBC, and considered to be an outgroup, not assigned to any of the lineages (Gutierez et al., 2005; Bañuls, 2015; Brites \& Gagneux, 2017). Four of the lineages are considered to be "ancient", they are the following: Lineage 1 (also known as Indo-Oceanic), Lineage 5 (also known as $M$. africanum West Africa 1), Lineage 6 (also known as M. africanum West Africa 2) and Lineage 8 (Gagneux et al., 2006; Ngabonziza et al., 2020, Coll et al., 2014). The most recently described Lineage 8 is characterized based on the genomic sequence of 2 multidrog-resistant (MDR) strains so far, which were isolated from the African Great Lakes region (Ngabonziza et al., 2020). This lineage probably diverged after " $M$. canettii", but before the most recent common ancestor (MRCA) of the rest of the MTBC. The "modern" lineages are Lineage 2 (also known as 
East-Asian), Lineage 3 (also known as East-African-Indian) and Lineage 4 (also known as Euro-American) (Gagneux et al., 2006; Coll et al., 2014; Bañuls, 2015). Strains, belonging to Lineage 7 are described from Ethiopia and the Horn of Africa (Firdessa et al., 2013; Tessema et al., 2013, Coll et al., 2014, Bañuls, 2015). In an evolutional point of view it can be placed between the "ancient" and "modern" lineages. The so-called M. tuberculosis sensu stricto consists Lineage 1-4 and L7 (Gagneux, 2018).

It has been shown that the strain type may have an impact on the outcome of disease, vaccine efficiency, and development of drug resistance (Coll et al., 2014). The M. tuberculosis lineages can be further divided into sublineages or families, which are showing not only different geographical distribution, but also appear to be transmitted with different efficiency (Bañuls et al., 2015). There are groups, which appear globally such as the Haarlem (L4.1.2) and Latin American (4.3), while there are also certain groups, which can be found only in a couple of countries, such as Ghana (L4.1.3) Cameroon (L.4.6.2) (Stucki et al., 2016).

\subsubsection{Phylogeny of animal-adapted MTBC members}

The animal-adapted strains - based on genotyping studies and genomic deletion analyses, characterised by specific deletions in RD 7-10 - are forming a separate group, which can be further divided and this clade can be tracked back to one common ancestor (Brosch et al., 2002; Mostowy et al., 2005; de Jong et al., 2010a; Brites et al., 2018; Parsons et al., 2019) (See the detailed list of genes/ORFs included in RD 7, 8, 9, 10 in: Gordon et al., 1999 Supplementary Table 4). Parsons and colleagues (2019) are distinguishing 2 sub-lineages, the first occurs primarily in Europe and Asia, while the second is including the strains evolved in Africa. The former one is including M. pinnipedii, M. orygis, M. caprae, M. microti and M. bovis, while the latter one is including the "chimpanzee bacillus", "dassie bacillus", M. mungi and M. suricattae. In contrast, with the previous differentiation, Brites and colleagues (2018) distinguished 4 clades among the animal-adapted species, or ecotypes. Clade A1 is identical with the second group of the aforementioned categorisation, Clade A2 includes $M$. microti and M. pinnipedii, Clade A3 includes M. orygis and Clade A4 includes M. bovis and M. caprae.

Within the MTBC, a clade can be distinguished according to a common deletion of RD9 (Rv2073c locus, oxidoreductase) (Dippenaar et al., 2015). This deletion is shared by all the animal-adapted MTBC members, and strains belonging to $M$. africanum type I (L5, L6) (Niemann et al., 2004; de Jong et al., 2010a; Dippenaar et al., 2015; Gagnaeux, 2018; 
Parsons et al., 2019). Further deletions are characteristic to the animal-adapted members, and strains of WAF2, namely the RD7, RD8, RD10 (de Jong et al., 2010a; Dippenaar et al., 2015; Parsons et al., 2019). Interestingly strains of WAF2 have not been reported from animal TB cases (Comas et al., 2013; Orgeur \& Brosch, 2018). M. bovis and other animaladapted member were found to have smaller genome size, compared to human-adapted MTBC members (Cole et al., 1998; Garnier et al., 2003; Bañuls et al., 2015).

These data support the notion of the extant human pathogen, $M$. tuberculosis was already a human pathogen bacillus, when $M$. africanum and later M. bovis diverged, in contrast with the earlier hypothesis, which suggested that human $\mathrm{TB}$ is a result of transmission from animals during the Neolithic transition (Brosch et al., 2002; Gagneux, 2012; Comas et al., 2013; Bañuls et al., 2015). In fact, genetic data implies all animal-adapted members diverged from, or at least next to the L6, which is considered as an "ancient" lineage among humanadapted MTBC members (de Jong et al., 2010a; Comas et al., 2013; Coll et al., 2014; Bañuls et al., 2015; Dippenaar et al., 2015; Orgeur \& Brosch, 2018).

\subsubsection{The most common hypothesis regarding the origin of MTBC members}

It is hypothesised that an environmental Mycobacterium evolved into an intermediate bacterium, able to cause tuberculosis, what was closer to " $M$. canettii". As probable link between NTM and tuberculous bacteria primarily M. kansasii has been suggested, along with M. marinum and M. ulcerans (Wang et al., 2015a; Chisolm et al., 2016; Jankute et al., 2017; Boritsch \& Brosch, 2018). The idea of the ancestor of MTBC evolving from an environmental bacterium is supported not only by genetic data, but also by the examination of the lipid constituents of the cell wall (Jankute et al., 2017). With the changes in the cell wall constituents, especially those regarding to the outermost layer of the mycobacterial membrane, an environmental Mycobacterium with low-pathogenicity and more hydrophilic surface might became more hydrophobic, pathogenic, able to be transmitted by aerosol. Evidences are appearing about megafaunal $\mathrm{TB}$ in the late Pleistocene, supporting the hypothesis of an evolutional step involving hordes of megafauna as a link on the way to become an " $M$. canettii" related low-pathogenicity organism from an environmental Mycobacterium (Jankute et al., 2017; Minnikin et al., 2020).

For summary, the extreme genetic similarity suggests that all MTBC members are sharing one common ancestor, which was probably a human pathogen with African origin (Brosch et al., 2002; Gutierez 2005; Comas et al., 2013; Orgeur and Brosch 2018; Ngabonziza et al., 
2020). This common ancestor is hypothesised by several authors to be a " $M$. canettii"-like Mycobacterium (Supply et al., 2013; Brites \& Gagneux, 2017; Supply \& Brosch 2017; Orgeur \& Brosch 2018). This idea is supported by the fact that the extant STB group is a link between environmental and human pathogenic mycobacteria, since it has a potential environmental reservoir, but shows no human-to-human transmission, however it is causing tuberculosis exclusively in humans although (Koeck et al., 2011).

The common African origin of MTBC and humans, as well as genetic data (e.g. similar dating of major branching events) indicates co-evolution of MTBC and modern humans for tens of thousands of years (Gagneux, 2012; Comas et al., 2013, Loddenkemper et al., 2018).

\subsection{The mycobacterial cell wall constituents}

Although the exact cell wall (CW) structure of the Mycobacterium genus is still not known, its remarkable complexity is out of question (Jackson, 2014; Minnikin et al., 2015; Daffé \& Marrakchi, 2019; Dulberger et al., 2020). The mycobacterial CW is rich in various lipids, some of them can be commonly found in all bacteria, but many of them are unique (Figure 2). The lipids can add up to $40 \%$ of the dry cell mass (Jackson, 2014; Daffé \& Marrakchi, 2019; Batt et al., 2020). The outstandingly high lipid content, and sophisticated lipid arrangement are the two factors commonly mentioned as the reason of the high impermeability of mycobacterial CW (Jackson, 2014; Minnikin et al., 2015; Daffé \& Marrakchi, 2019; Batt et al., 2020; Dulberger et al., 2020).

In this section the main lipid families are going to be introduced and their proposed localisations will be noted. 


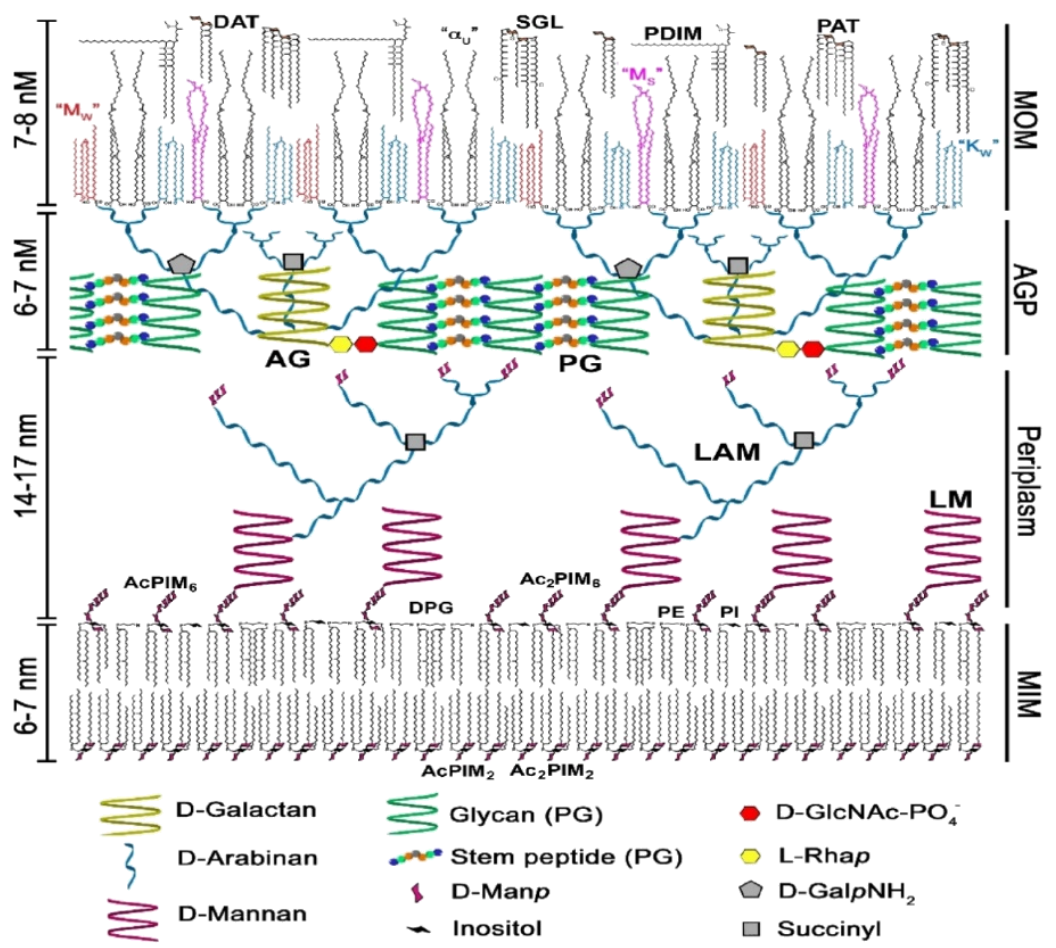

Figure 2: Schematic picture of CW structure in M. tuberculosis (Minnikin et al., 2015)

Beside the conventionally occurring polar lipids in the plasma membrane (e.g. phosphatidylethanolamine, phosphatidylinositol), mycobacteria have a polar lipid family called phosphatidylinositol mannosides (PIMs), which is consisted of a phosphatidylinositol core decorated with mannose residues (Minnikin et al., 2015; Batt et al., 2020). PIMs are described as constituents of the inner most membrane layer of mycobacteria (Figure 2) (Minnikin et al., 2015; Daffé \& Marrakachi, 2019; Batt et al., 2020; Dulberger et al., 2020).

Further CW elements, the lipomannan (LM) and lipoarabinomannan (LAM) are lipoglycans, having the same manno-phosphatidylinositol anchor as PIMs do, with additional glycolisation and they are sharing the same synthesis path (Kaur et al., 2006; Minnikin et al., 2015; Batt et al., 2020). In the case of LAM arabinose branches are connecting to the mannose residue. LM and LAM presents several lipid anchor moieties, with they can contribute in the conformation of inner and outer membrane, but since LM and LAM are sharing the same anchoring structure with PIMs probably they are supposed to be at least anchored in the innermost layer of CW (Figure 2) (Minnikin et al., 2015; Daffé \& Marrakachi, 2019; Batt et al., 2020; Dulberger et al., 2020).

The arabinogalactan (AG) is build up from branched arabinose chains, which are linked to galactose units of galactan (Alderwick et al., 2015; Dulberger et al., 2020). Peptidoglycan (PG) is composed of peptides bonded to acetylmuramic acid and acetylglucosamin sugars. 
AG and PG are covalently linked to each other with a spacer unit, moreover the arabinose domains of AG serve as anchorage for MAs (Minnikin et al., 2015; Daffé \& Marrakachi, 2019; Batt et al., 2020; Dulberger et al., 2020). The AG-PG matrix can be found approximately as a middle layer of mycobacterial CW (Figure 2).

Mycolic acids (MAs) are long chain $\alpha$-alkyl- $\beta$-hydroxy fatty acids (FA) (Watanabe et al., 2001; Abrahams \& Besra, 2016; Batt et al., 2020; Dulberger et al., 2020;). These characteristic chemical components are usually 70-90 carbon atom molecules in the genus Mycobacterium (Minnikin, 1982; Minnikin et al., 2015; Batt et al., 2020). Two parts of mycolic acid can be differentiated, a longer meromycolate chain (C42-C62) and a long saturated $\alpha$-chain (C24-C26) (Figure 3) (Abrahams \& Besra, 2016; Batt et al., 2020; Dulberger et al., 2020). Three MA-classes can be distinguished as the $\alpha$-mycolates, the ketomycolates and the methoxymycolates (Figure 3) (Watanabe et al., 2001; Minnikin et al., 2015; Abraham \& Besra, 2016; Batt et al., 2020). Keto- and methoxymycolates contain ketone or methoxy group, and an adjacent methyl branch. The $\alpha$-mycolates have a cyclopropane ring, always in cis-configuration, while keto- and methoxymycolates can be further differentiated according to their cyclopropane ring either being in cis- or transconfiguration. These long chain lipids can be found in the outer membrane of mycobacterial $\mathrm{CW}$ and the majority of them are covalently bound to AG-PG matrix (Figure 2) (Jackson, 2014; Minnikin et al., 2015; Daffé \& Marrakachi, 2019; Batt et al., 2020; Dulberger et al., 2020).
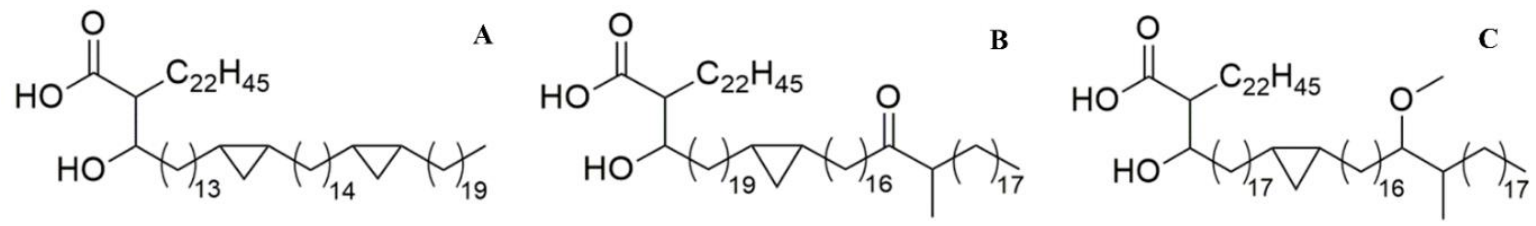

Figure 3: The schematic structure of mycolic acids. A: $\alpha$-mycolate B: Ketomycolate C: Methoxymycolate.

In the $\mathrm{CW}$, mycolic acids can be also found esterified, mainly to trehalose, also referred as "cord factor", as trehalose dimycolate (TDM), trehalose monomycolate (TMM) in various proportions (Jackson, 2014; Minnikin et al., 2015; Abrahams \& Besra, 2016; Daffé \& Marrakachi, 2019; Batt et al., 2020; Dulberger et al., 2020). TMM and TDM can be localised to the outer membrane of mycobacterial CW (Figure 2). Other MA esters are the glucose 
monomycolates (GMM) and monomycolic glycerols (MMG) (Jackson, 2014; Minnikin et al., 2015).

The relatively large ( C90) phthiocerol dimycocerosate (PDIMs) (Figure 4) and the phenolphthiocerol dimycocerosate are multimethyl branched long-chain FAs (mycocerosic acid (MC)) esterified mainly with phthiocerol and phenolphthiocerol long-chain diols (Daffé \& Lanéelle, 1988; Minnikin et al., 2015; Batt et al., 2020). MCs can be found only in the strains of M. tuberculosis, Mycobacterium bovis, Mycobacterium gastri, Mycobacterium haemophilum, Mycobacterium kansasii, Mycobacterium leprae, Mycobacterium marinum and Mycobacterium ulcerans (Redmann et al., 2009), in the outer layer of mycobacterial membrane. Phenolic glycolipids (PGLs) are similar to phenolphthiocerol dimycocerosate, but the former one is having antigenic oligosaccharides linked to the phenolic residue (Daffé \& Lanéelle, 1988; Minnikin et al., 2002; Redman et al., 2009; Minnikin et al., 2015; Batt et al., 2020).

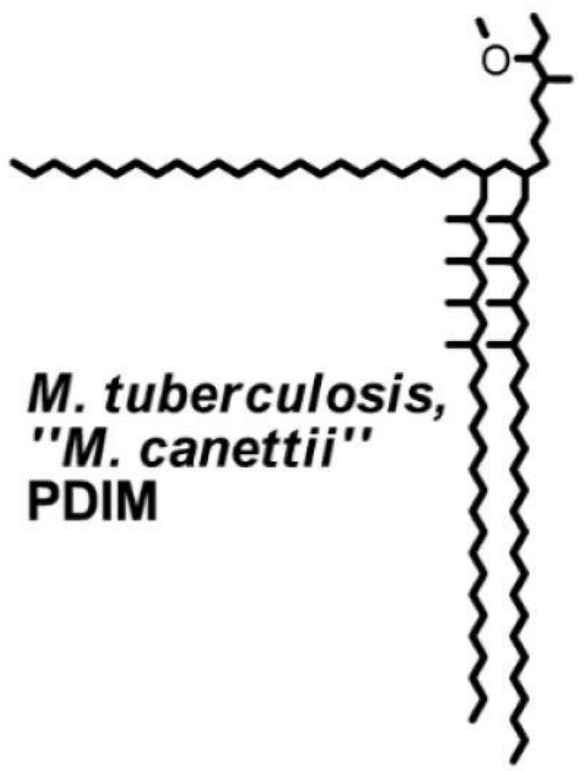

Figure 4: Simplyfied structure of PDIM (Minnikin et al., 2015).

Other free lipids are diacyl trehaloses (DAT), pentaacyl trehaloses (PAT) and sulfated trehalose glycolipids (SGLs), belonging to acyl trehaloses (Minnikin et al., 2015; Batt et al., 2020; Ortalo-Magné et al., 1996). These lipids are trehalose-based glycolipids acylated with multimethyl branched FAs (Minnikin et al., 2015; Jankute et al., 2017; Batt et al., 2020). Among PATs one, containing C27 mycolipenic acid (ML) has to be highlighted as it can be found only in M. tuberculosis. 
Lipooligosaccharids (LOS) are a series of highly polar lipids (Minnikin et al., 2015; Batt et al., 2020). LOSs are built up from a trehalose-containing saccharide core, which is acylated with multimethyl branched FAs on the trehalose that is also glycosylated with mono- or oligosaccharides. This lipid family is absent in MTB strains, however it can be found in " $M$. canettii” (Minnikin et al., 2015; Jankute et al., 2017; Batt et al., 2020)

An other group of free lipids are the glycopeptidolipids, which can be found in nontuberculosis causing Mycobacterium species (Batt et al., 2020). The free lipids most probably can be found in the outer layer of the mycobacterial CW (Figure 2) (Jackson, 2014; Minnikin et al., 2015; Batt et al., 2020; Dulberger et al., 2020), but in some of the literature they were suggested to be constituent of the mycobacterial capsule (Daffé \& Marrakachi, 2019).

Regarding the free lipids, PGLs are less characteristic in MTB, however, they are present for example in "M. canettii", M. bovis, M. marinum and M. leprae (Minnikin et al., 2015; Jankute et al., 2017; Batt et al., 2020). "M. canettii" presents similar PGLs to M. kansasii, however in the former one the main tetraglycosyl PGL underwent on a sugar loss (Minnikin et al., 2015; Jankute et al., 2017). Phthiodiolone dimycocerosates can be found in $M$. kansasii, but are replaced by a full set of the PDIMs in " $M$. canettii". The trehalose-based glycolipids can be found in the CW of "M. canettii" and MTB, but not in M. kansasii. SGLs, similarly to the former acyl-trehalose families, are primarily produced virulent strains of mycobacteria. LOSs are absent in many modern MTB strains, but are produced by " $M$. canettii" and various NTM species (Minnikin et al., 2015; Jankute et al., 2017; Batt et al., 2020). Due to these changes, the hydrophobicity of mycobacterial CW enhanced in the pathogenic members of the modern MTBC (Minnikin et al., 2015; Batt et al., 2020; Jankute et al., 2017).

\subsection{The main steps in the pathogenesis in the establishment of tuberculosis}

M. tuberculosis needs to establish pulmonary lesions in order to spread efficiently (Orgeur $\&$ Brosch, 2018). MTB spreads via inhaling droplets filled with bacilli, which are projected in the air while coughing, sneezing or even talking (Flynn \& Chan, 2001; Bañuls et al., 2015; Getahun et al., 2015). As the first step towards to establish an infection the bacilli have to get into the lungs by inhaling respiratory droplets, which are containing particles small enough to reach the distal alveoli (Bermudez \& Sangari, 2001; Pieters, 2001; VelascoVelázquez, 2003; Rock et al., 2008; Ahmad, 2011; Philips \& Ernst, 2012; Orme \& Basaraba, 
2014). However, the bacilli are phagocytosed by alveolar macrophages, in the attempt to eliminate bacilli through a range of assault methods, they are able to survive and even multiply intracellular. By infecting the alveolar macrophages, MTB can access the interstitium of the lungs, and further process with the infection (Pai et al., 2016). With the migration of further macrophages, lymphocytes and a wide range of other host cells to the site of infection the formation of granuloma can be initialised (Flynn \& Chan, 2001; Ahmad, 2010). From the host's point of view, the granuloma separates the bacilli from the host, prevents they spread and also concentrates the immune response to site, on the other hand it can be maintained due to chronic stimulation of the immune cells and form a basis for a tuberculous lesion (Flynn \& Chan, 2001).

Both the human immune system and MTB evolved sophisticated strategies against each other (Dulberger et al., 2020). While from the side of the host CD1 family (CD1a-CD1d) has evolved the ability to present for example MAs, SGLs, LAM, and PIMs (Ernst et al., 1998; Moody et al., 2000; Gilleron et al., 2004; Roy et al., 2014; Busch et al., 2016; Chancellor et al., 2017; Dulberger et al., 2020), MTB can avoid the recognition of the bacilli, and cytokine responses, also inhibit TLR-2 (Toll-like receptors) by SGLs (Blanc et al., 2017; Dulberger et al., 2020). A set of $\mathrm{T}$ cells are enabling the recognition of mycobacterial antigens to initiate cytokine response and the clearance of infected cells (Roy et al., 2014; Chancellor et al., 2017; Dulberger et al., 2020).

MTB also using PDIM to mask some pathogen-associated molecular patterns and protects it against reactive nitrogen (Rousseau et al., 2004; Cambier et al., 2014; Dulberger et al., 2020). Among other strategies MTB achieves to recruit naïve macrophages instead of microbicidal andones or modifies the processing and availability of peptide antigens for MHC classes (Tobian et al., 2003; Cambier et al., 2014; Saini et al., 2016; Dulberger et al., 2020). TDMs take part in blocking the fusion of phagosomes with lysosomes, promoting granuloma formation and enhancing granuloma caseation (Hunter et al., 2006; Ishikawa et al., 2009; Dulberger et al., 2020).

If the bacilli are not eliminated from the host after the initial infection two main scenarios can be drawn (Flynn \& Chan, 2001; Fogel, 2014; O’Garra et al., 2013; Getahun, 2015). In some individuals, active disease can form in a relatively short time (1-3 years), but more commonly a latent infection will develop. Individuals with latent infection will not show any 
symptoms, also will not spread the disease, however in an estimated 5-10\% of latent cases the infection will re-activate.

\subsubsection{Pulmonary tuberculosis}

When the host-pathogen equilibrium can not be established, or it gets broken active TB infection is established, which appears as pulmonary TB in most of the cases (Godreuil et al., 2006; Rodriguez-Takeuchi et al., 2019). Initially, the granuloma goes through liquefaction forming cavities (Godreuil et al., 2006). In the established micro-environment MTB cells can grow, but macrophages can not survive. The symptoms of pulmonary TB are persistent cough and sputum production. In the case the disease proceeds to a more advanced stage sputum also can contain blood, patient loses appetite and weight, moreover fever, sweating over night and thoracic pain can appear.

Development of periosteal new bone formation (PNBFs) on the visceral surface of the ribs can be initiated by several aetiologies, one of the main causis is - in an indirect way, via a secondary pleural infection - pulmonary TB (Roberts et al., 1994; Santos \& Roberts, 2001, 2006; Matos \& Santos, 2006). These lesions are widely used in TB-related macroscopic analysis (Figure 5).

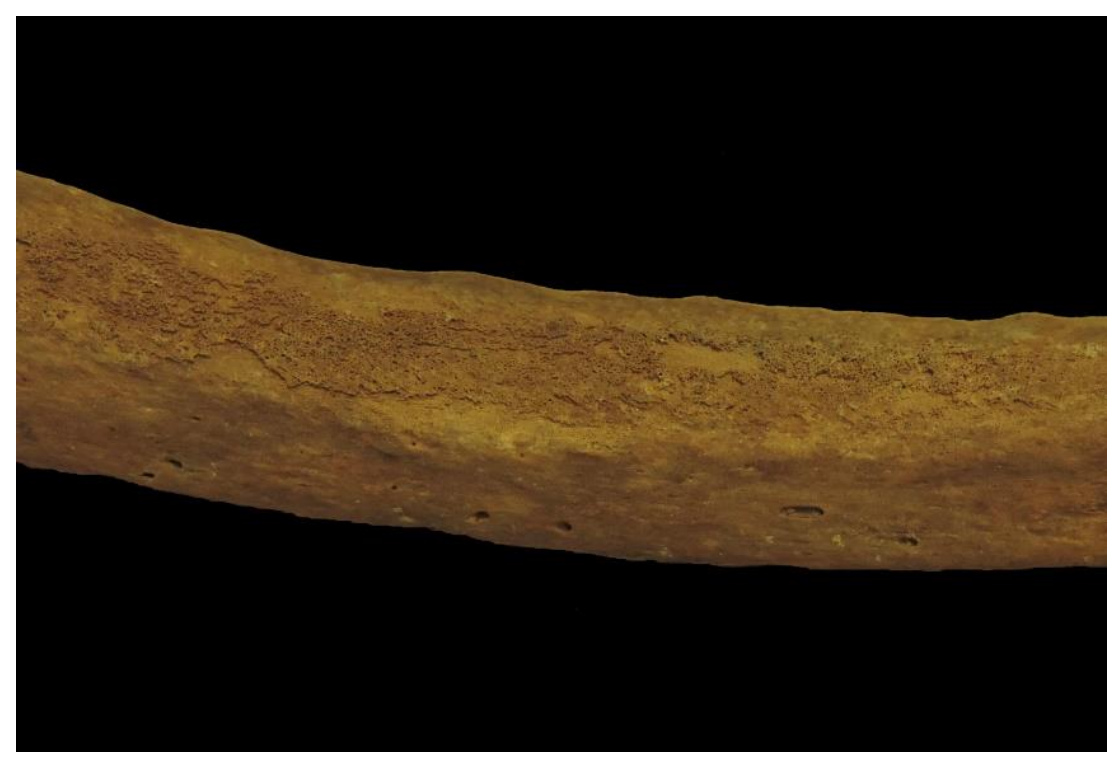

Figure 5: PNBF on the visceral surface of a rib (Bélmegyer-Csömökidomb, grave no.:12).

\subsubsection{Extra-pulmonary tuberculosis}

The replication of the bacilli in macrophages and lymph nodes can lead to dissemination and the establishment of extra-pulmonary TB (Getahun et al., 2015). Extra-pulmonary TB was registered in 16\% of all incident cases in 2019 (WHO, 2020). The two most commonly occurring forms are lymphadenitis and pleural TB (Golden \& Vikram; 2005; Rodriguez- 
Takeuchi et al., 2019). As the result of the mycobacterial dissemination further extrapulmonary forms can develop such as, abdominal $\mathrm{TB}$, miliary $\mathrm{TB}$, genitourinary $\mathrm{TB}$, osteoarticular TB, CNS TB, etc.

The osteoarticular tuberculosis develops in a low number of TB cases, however it occurs in 10-35\% of people with extra-pulmonary TB (Golden \& Vikram, 2005; Spekker et al., 2018; Rodriguez-Takeuchi et al., 2019). The half of skeletal tuberculosis cases are involving the spine (Goldan \& Vikram, 2005; Spekker et al., 2018; Rodriguez-Takeuchi et al., 2019). In the early stage of spinal TB, the hypervascularisation of the vertebral bodies (traces of vertebral vasculitis) can be indicative (Baker et al., 1999; Pálfi et al., 2012; Mariotti et al., 2015; Spekker et al., 2018, Spekker, 2018). A very distinctive manifestation, tuberculous spondylitis (Pott's disease) affects mainly the thoracic region, typically involving two or more vertebrae, however in rare cases, solitary vertebral involvement is also recorded (Aufderheide \& Rodríguez-Martín, 1998; Ortner, 2003; Golden \& Vikram, 2005; Spekker et al., 2018; Rodriguez-Takeuchi et al., 2019). Due to the development of osteolytic lesions, wedging and eventually the collapse of vertebral bodies can be observed, leading to different deformities, such as to the so called "Pott's gibbus", which is a sharply angular kyphosis (Figure 6A) (Aufderheide \& Rodríguez-Martín, 1998; Ortner, 2003; Spekker et al., 2018). Tuberculous spondylitis as well as extra-spinal TB can be accompanied by the formation of cold abscess around the osteolytic lesion, which can extend downwards, affecting not only the underlying bones but the ligaments and soft tissue, however cold abscess can be originated from the soft tissue, as well (Aufderheide \& Rodríguez-Martín, 1998; Ortner, 2003; Pálfi et al., 2012; Esteves, 2017; Procopie et al., 2017; Spekker, 2018). The extension of the cold abscess implies erosive cortical bone destruction and reactive new bone formation (Figure 6B). 


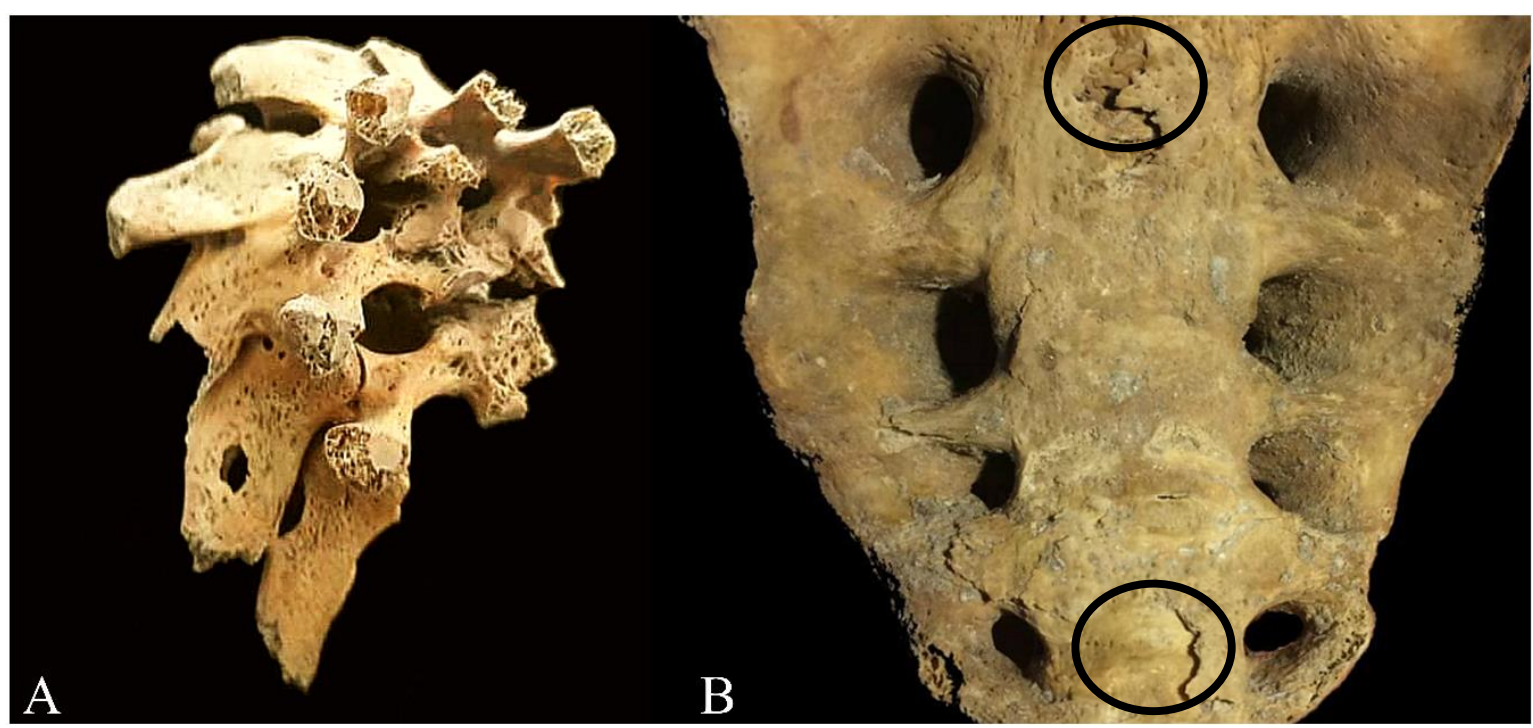

Figure 6: A: Pott's gibbus on the thoracic region (Győrszentiván-Révhegyi tag, grave no.: S0603; B: Probable traces of an overlying cold abscess on the ventral surface of a sacrum (Sárrétudvari-Hízóföld, grave no.: 5)

The second most common form of skeletal tuberculosis is tuberculous arthritis, typically affecting high-weight bearing joints, principally the knee (gonitis tuberculosa) and hip (coxitis tuberculosa) (Figure 7) in a monoarticular form (Golden \& Vikram, 2005; Spekker, 2018; Rodriguez-Takeuchi et al., 2019). It might begin on the synovial membrane, from where it continues with the erosion of the margin of the articular cartilage, and the destruction eventually can reach the bone (Rodriguez-Takeuchi et al., 2019). Extra-spinal TB osteomyelitis is a rare manifestation, mainly affecting the long and short tubular bones (Malaviya \& Kotwal, 2003; Spekker, 2018; Rodriguez-Takeuchi et al., 2019). Pathogens first induce granulomatous inflammation in the cancellous bone, resulting round or oval shaped osteolytic lesions on the site. In half of the osteoarticular TB cases pulmonary TB can be detected via chest radiography (Rodriguez-Takeuchi et al., 2019). 


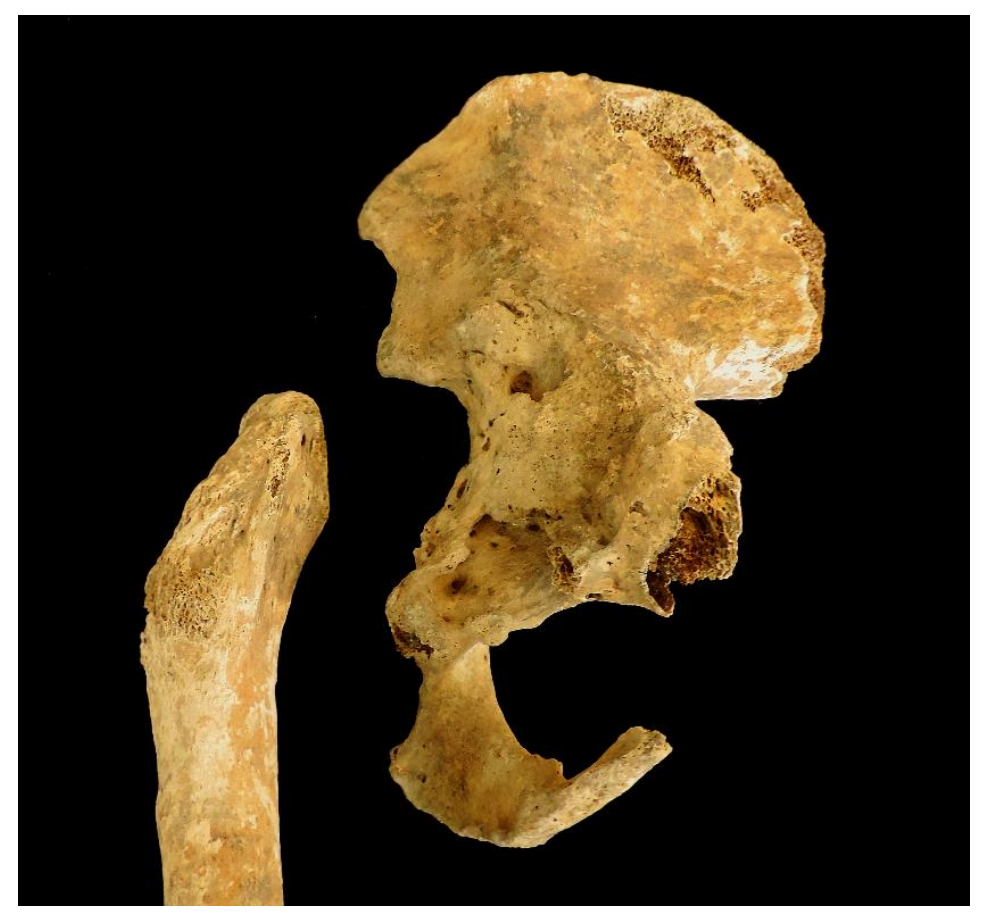

Figure 7: Coxitis tuberculosa (Bélmegyer-Csömökidomb, grave no.: 90)

In the traditional paleopathological practice the signs of osteoarticular TB have served as a good indicator of the presence of TB infection, however in later studies beside the described lesions, periosteal new bone formation on the long bones with a diffuse bilateral appearance has been also proven to be useful indicators of TB (e.g. Aufderheide \& Rodríguez-Martín, 1998; Marcsik et al., 1999, 2009; Pálfi \& Marcsik, 1999; Hershkovitz et al., 2002; Maczel, 2003; Ortner, 2003; Pálfi \& Molnár, 2009; Pálfi et al., 2012; 2015; Spekker et al., 2012; Kajdocsi Lovász, 2015; Mariotti et al., 2015; Masson et al., 2015; Molnár et al., 2015; Paja et al., 2015).

Extra-pulmonary TB can affect also the CNS (Golden \& Vikram, 2005; Rock et al., 2008; Pálfi et al., 2012; Rodriguez-Takeuchi et al., 2019; Spekker et al., 2020a; Spekker et al., 2020b). Although the occurrence of CNS TB is very low, it represents one of the most devastating form of TB and includes several manifestation forms, such as tuberculous meningitis, intracranial tuberculomas and spinal tuberculous arachnoiditis (Rock et al., 2008; Spekker et al., 2020a; Spekker et al., 2020b). CNS TB can occur after haematogenous spread and starts with the development of small tuberculous foci in the brain, spinal cord or meninges (Rock et al., 2008; Spekker, 2018). Bacilli in the foci can either stay dormant or with the enlargement or rupture of one or more Rich foci can establish active CNS TB (Rock et al., 2008; Spekker et al., 2020a; Spekker et al., 2020b). The primary manifestation of CNS TB is tuberculous meningitis (TBM). Although it represents a very low ratio among all TB 
infected cases, it has been found that many people identified as patients died of pulmonary TB also had tubercles in their CNS (Vinnard \& Macgregor, 2009). The most common form of CNS TB is leptomeningitis (Golden \& Vikram, 2005; Rock et al., 2008). Due to the formation of a dense gelatinous exudate the flow of cerebrospinal fluid can be distracted, leading to hydrocephalus (Rock et al., 2008). Tuberculomas can also develop in the brain, when tubercles in the brain parenchyma grow but without rupturing.

Granular impressions (GI) (Figure 8) on the inner surface of the skull have been suggested to be TBM related lesions Schultz, 1993, 1999, 2001, 2003; Maczel, 2003; Spekker, 2018; Spekker et al., 2020a). They might be the result of pressure atrophy caused by the tubercles formed in the dura mater. Abnormally pronounced digital impressions (APDIs) can develop due to a long lasting increased endocranial pressure forming shallow depressions (Schultz, 1993, 2001, 2003; Spekker et al., 2020b). Abnormal blood vessel impressions (ABVIs) and periosteal appositions (PAs) (Figure 8) on the endocranial surface can occur as a result of inflammatory or haemorrhagic reaction caused (Schultz, 1993, 1999, 2001, 2003; Hershkovitz et al., 2002; Maczel, 2003; Spekker, 2018).

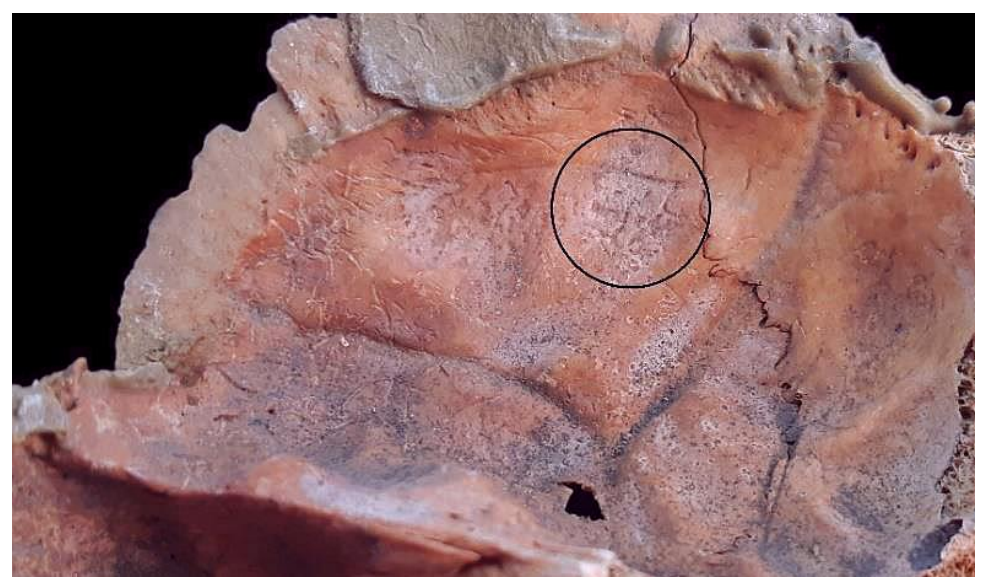

Figure 8: GI covered with PA on temporal bone (Szentes-Borbásföld, grave no.: 9)

However, the aforementioned GI, APDI, ABVI, PA, are not undoubtedly pathognomonic lesions they involvement in paleopathological investigations is necessary to draw a more exact paleoepidemiological picture (Schultz, 1993, 1999, 2001, 2003; Maczel, 2003; Hershkovitz et al., 2002; Maczel, 2003; Masson et al., 2015; Molnár et al., 2015; Schultz \& Schmidt-Schultz, 2015; Spekker, 2018; Spekker et al., 2020a; Spekker et al., 2020b). 


\subsection{Molecular biological and analytical methods in the use of ancient TB detection}

As it was discussed above, paleopathology is using a broad variety of markers, which are observable by macroscopic investigations. However, as it was mentioned, skeletal TB and CNS TB develop in rare cases, moreover many markers are not pathognomic. To estimate the exact number of TB affected individuals in past populations is nearly impossible, however with the simoultaneous involvement of molecular biological and analytical techniques there are promising possibilities to draw a cleaner picture about the paleoepidemiology of TB.

\subsubsection{The development of aDNA techniques for TB diagnosis}

As the result of the mycobacterial DNA dissemination, the traits of the genomic material can be trapped in the mineralized tissue of the skeleton, in the dental root canal and in the pulp chamber (Donoghue et al., 2017). From a paleopathological point of view an advantageous attribution of mycobacteria is that their DNA is quite resistant to degradation due to the complex and protective $\mathrm{CW}$, as well as the high guanidine and cytosine proportion (Spigelman \& Donoghue, 2003; Donoghue et al., 2017). The first PCR-based detection of TB aDNA, extracted from morphologically TB positive ancient bone samples was published in 1993 (Spigelman \& Lemma, 1993). The results were verified by independent laboratories and sequencing. Shortly after, Salo and colleagues (1994) gained similar results from an other Pre-Colombian specimen, using the nested PCR targeting the same 123 bp region in the IS6110 locus. Later commercial kits and hot-start PCR were included in the investigations for better specificity from complex samples (Taylor et al., 1999; Donoghue et al., 2017). At the end of the '90s spoligotyping was also introduced in TB aDNA investigations and further markers were included such as mtp40 and oxyR (Taylor et al., 1999; Mays et al., 2001). In the 2000's the method was further supplemented with other PCR markers such as, IS1081, outer and internal primers for TbD1, RD deletion regions (Zink et al., 2001; Fletcher et al., 2003; Taylor et al., 2005; Hershkovitz et al., 2008). As in 2010's sequencing techniques had a breakthrough regarding sensitivity, speed as well as availability, whole genome sequencing, metagenomics analyses and hybridization capture with next generation sequencing have been also included in ancient TB research what helped researchers to extend the knowledge of the diversity and spread of mycobacterial pathogens (Bouwman et al., 2012; Chan et al., 2013; Bos et al., 2014; Kay et al., 2015). 


\subsubsection{The development of lipid biomarker based techniques for TB diagnosis}

An integrated procedure for the detection of characteristic lipid biomarkers was published in 1993 by David E. Minnikin and colleagues (Minnikin et al., 1993). The method included the detection of MAs, tuberculostearic acid (TSA) and MCs. After the lipid extraction lipids were purified by solid phase extraction (SPE) on normal phase (NP) cartridge. MA detection was carried out via HPLC-FLD (high performance liquid chromatograph connected to fluorescence detector) by the application of 9-anthrylmethyl ester derivatisation after reverse phase (RP) SPE purification. MAs were first separated according to type on NP-HLPC, then individual MA types have been further separated on RP-HPLC. TSA and MCs were derivatised with pentafluorobenzyl bromide (PFB) for GC-FID-ECD (gas chromatograph coupled with flame ionisation and electron capture detector) and GC-ECD, respectively.

However, the previously described method was developed for clinical diagnosis shortly after, it was used for the detection of ancient TB infection with minor changes (e.g. an initial RP-HPLC separation was added before preceding the NP-HPLC separation) by detecting MAs from a 1400 years old calcified pleura sample and two approximately 1000 years old rib samples of morphologically TB positive cases along with aDNA analysis (Gernaey et al., 1998; Donoghue et al., 1998; Gernaey et al., 2001). A new and more sensitive version of MA detection was published in 2008 by Hershovitz and colleagues (Hershovitz et al., 2008). The samples used for the demonstration were taken from a woman and an infant buried together having TB-related bone lesions. The individuals were unearthed from a 9000 years old, Neolithic excavation site, called Atlit-Yam. The extracted lipids were first derivatised with PFB, then purified on NP-SPE. Then PFB-MAs were further derivatised with pyrenebutyric acid (PBA) and purified on C18 RP-SPE. PBA-PFB mycolates were further extracted and analysed first by RP-HPLC-FLD. Components corresponding to PBA-PFB mycolates were collected for further analysation on NP-HPLC-FLD, where $\alpha$-, methoxyand ketomycolates were separated. The individual mycolate types were collected separately and examined on RP-HPLC-FLD, where individual mycolates were separated. In this study both individuals have been proven to be positive to TB by aDNA as well as mycolic acid examination.

A different approach was also introduced in first half of the last decade. This method was also principally developed for clinical diagnosis of TB (Szewczyk et al., 2013). The method based on HPLC-MS/MS examination, with electrospray ionisation (ESI). The analyses targeted 10 of the most abundant and characteristic MAs of M. tuberculosis, multiple 
reaction (MRM) pairs including $\alpha-$, methoxy- and ketomycolates. The preparation did not include any derivatisation, furthermore, the samples were analysed by flow injection analyses, both features contributed in the establishment of a rapid procedure. The method was first used on archaeological samples in the next year (Borowska-Strugińska et al., 2014). The samples derived from a 30-50 years old male, buried in the Neolithic period, whose macromorphological examination described him as a TB positive individual. The previously described clinical method was applied, but the MS detection was supplemented with further MA targets, monitoring 14 MRM transition pairs. The MA profile recorded from the examined samples presented a similar distribution to $M$. tuberculosis, moreover the lipid biomarker based results were confirmed by PCR analysis of the extracted aDNA.

A further optimised method was introduced for establishing mycocerosate profile and detecting C27 mycolipenic acid from historical bone samples, which was published in 2009 (Redman et al., 2009). The optimisation results were tested and demonstrated on samples taken from individuals of the Coimbra Identified Skeletal Collection. The examined biomarkers were C26, C27, C29, C30, C32, C33, C34 mycocerosic acids and C27 ML. The extracted MC and ML containing fraction was first derivatised with PFB and further extracted, and then purified on NP-SPE. The collected fractions were analysed on NP-HPLC due to the separation of multimethyl-branched FA-PFB esters from other PFB FA esters, and the multimethyl-branched FA-PFB esters were collected. For the proper timing of the fraction collection from the HPLC, two co-markers, decafluorobenzophenone (DFBP) and long-chain (C6, C8, C12, C16 and C18) esters of decafluorobenzhydrol were applied, which are eluting after and before the targeted fraction, as follows. The collected PFB-esters were measured by negative ion chemical ionisation gas chromatograph coupled with mass spectrometer (NI-CI GC-MS) in selected ion monitoring (SIM) mode. The C26, C33, C34 mycocerosic acids were excluded from their study as no definitive ion signals were observed. From the standard M. tuberculosis PN cells the C29, C30 and C32 MCs were extracted in the highest ratio, along with the C27 ML. Among the 49 examined bone samples 33 mycocerosate positive samples were found. 22 out of the 33 correlated with a positive diagnosis for tuberculosis, and only 2 individuals who were diagnosed with pulmonary tuberculosis presented negative results for mycocerosates. 


\subsubsection{Examples of the combined macroscopic, aDNA and lipid biomarker based examinations}

A 7000-year-old male skeleton, with signs of hypertrophic pulmonary osteoarthropathy (HPO) from the Hódmezővásárhely-Gorzsa Neolithic site has been widely examined (Masson et al., 2013; Donoghue et al., 2017). HPO is a periosteal new bone formation, what appears symmetrical (diffuse or distal) mainly on the shaft of the long bones. Its appearance as a primary pathology is considered to be very rare, the secondary form is a more common pathological feature. The formation of HPO can be initiated by several diseases, such as cancer, abdominal neoplasm, liver cirrhosis, chronic intrathoracic infection (such as TB). The macroscopic examinations indicated that the described secondary HPO was the result of TB infection. Multiple samples taken from this individual were analysed for the presence of TB derived aDNA, MA and MC, C27 ML. Some samples were positive to the presence of IS1081, but not for IS6110, the MA analyses presented a weak initial RP-HPLC profile, in a similar distribution to $M$. tuberculosis standard, moreover the MC and ML examination provided strong evidence of the presence of MTB. Later 4 other individuals from the site were examined in a similar manner, as they also presented TB-related lesions based on macromorphological observation (Masson et al., 2015; Donoghue et al., 2017). TB infection was confirmed in the case of two individuals by strong MC and clear MA profiles, in the case of one individual by strong MC and weak MA, and in one case by strong MC, weak MA profile and positive aDNA analysis.

An extensive study involving 20 individuals was published in 2015, where 6 individuals presented signs of skeletal TB, and other TB-related lesions were described on 13 individuals (Pálfi et al., 1992; Pálfi \& Cernus, 1990; Molnár et al., 2015). Samples taken from 4 individuals were positive for MA, MC, ML, infection was also confirmed by aDNA in one case among them, and one case indicated a M. tuberculosis - M. leprae co-infection (Molnár et al., 2015; Donoghue et al., 2017). Samples of 7 individuals presented clear traits of C27 ML, but the MA and MC signals were less convincing, 5 among them was supported by positive aDNA results. Samples of 2 individuals presented good C27 ML, weak MC preservation, without observable trait of MA, one of them with positive aDNA results. In one case positive aDNA amplification was supported by weak C27 ML traits. Samples of 4 individuals provided inconclusive profile for MC and C27 ML, however one of them was proved to be TB positive by aDNA examination. 2 individuals showed no evidence of lipid biomarker presence, but one of them was successfully confirmed by aDNA examination. 
The oldest human cases verified by lipid biomarkers were unearthed in the archaeological site Dja'de el Mughara, Northern Syria (10.8-10.3 thousand years old, pre-domestication era) and Tell Aswad, Southern Syria, (10.2-9.6 thousand years old, early-domestication era) (Baker et al., 2015; Dongohue et al., 2017). Multiple samples of 2 individuals were tested for the traits of both TB related lipid biomarkers and aDNA. One of the individuals was tested positive for TB by aDNA examination, moreover it presented clear C32 mycocerosate peaks, as well as a convincing signal for C27 mycolipenate. Samples taken from the other individual presented strong C27 mycolipenate and weak mycocerosate signals, with no amplified aDNA fragments. The macromorphological analyses suggested TB infection in both cases.

The oldest TB case verified by aDNA and lipid biomarker is derived from samples taken from the metacarpal of a Bison antiquus, dated to be 17000 years old (Pleistocene age), unearthed from Natural Trap Cave, Wyoming, USA (Lee et al., 2012; Donoghue et al., 2017). The aDNA examination confirmed the presence of MTBC DNA traits, with the exclusion of M. bovis. MA profile was recorded, however it was weak, but the MC and ML profiles were strong. On the sampled metacarpal bone pronounced lesions "undermining the articular surface" were observed, what correlates with lesions in humans.

The oldest evidence of TB in Argentina was verified by macroscopic technique as well as both lipid biomarkers and aDNA analysis (Luna et al., 2020). TB related lesions were observed on several vertebrae, ribs, on the ilia and appendicular skeleton. Multiple samples were also taken for both molecular biological and analytical examinations. One of the rib samples provided excellent, diagnostic MA profile on all the levels of HPLC analysis. The same rib sample provided strong positive profile of MCs and small indecisive signal of C27 ML. Slightly weaker, but similar profile was also gained from an other rib sample. However, recovering high quality aDNA for whole genome sequencing was not achieved, positive result for the IS6110 insertion sequence was recorded with the analyses of the sample taken from the same rib, which provided the best lipid biomarker results. The given MC profile with the major C29 MC component indicates the presence of a slightly unusual member of the MTBC. MCs of M. bovis can be smaller compered to M. tuberculosis. The authors suggested that investigation of $M$. pinnipedii would be informative, as this species was proposed to take part in the transfer of ancient TB from marine mammals, (e.g. seals) to old costal Peruvians 1000 years ago (Bos et al., 2014; Luna et al., 2020). 
When both mycobacterial aDNA and lipid biomarker analysis is carried out, it is possible to recover the latter one from the samples that have already undergone DNA extraction (Lee et al., 2012; Donoghue et al., 2017). The above described cases are excellent examples of the increased efficiency achieved by the combination of different approaches.

For the verification of new methods, and the estimation of reliability of new markers in macroscopic analysis paleopathologists usually use well-documented collections of skeletons and mummies from the pre-antibiotic era (Roberts et al., 1994; Santos \& Roberts, 2001; 2006; Pálfi et al., 2012; Spekker, 2018; Spekker et al., 2020a; 2020b) The Vác mummy collection is one of the well-documented and broadly studied collections. Among other advantages of this collection, several results of TB-related investigations and individual data are available regarding this group (Szikossy et al., 1997; Pap et al., 1999; Fletcher et al., 2003; Chan et al., 2013; Kay et al., 2015; Pap et al., 2017). As these mummies are dated to the modern age, but they are from the pre-antibiotic era, they also represent an excellent link between recent and archaeological samples. They were discovered during the renovation of the Dominical Church of Vác (1994-1995) a long-forgotten crypt (Pap et al., 1999) (Figure 9). The chamber had been in use between 1731 and 1838 as a burial site for middle-class families and ecclesiastical individuals. On the site, the remains of 265 individuals were found and, fortunately, most of them were naturally mummified due to the special microclimatic features. The mummies are curated in the Department of Anthropology, Hungarian Natural History Museum, Budapest. Since then, the remains have undergone several investigations from many aspects, with a broad variety of techniques, such as morphological analysis, dermatological examination, X-ray imaging, 3D reconstruction, and aDNA examination (Szikossy et al., 1997; Pap et al., 1999, 2017; Fletcher et al., 2003; Kustár et al., 2011; Chan et al., 2013; Cseplák et al., 2015; Kay et al., 2015). As TB was already a growing burden all around Europe, including Hungary and the suspicion of TB-infected cases arose based on macroscopic observations, an extended screening was carried out searching for DNA traits of the infectious agent (Fletcher et al., 2003). 350 samples belonging to 168 individuals were examined by Fletcher and her colleagues. The samples were taken from the lungs, pleura, abdomen, ribs, hair, teeth, and clothing. In their study $55 \%$ of the individuals proved to be infected with Mycobacterium tuberculosis complex (MTBC), based on the PCR amplification of IS6110,19-kDa antigen and MPB70 antigen genes, as well as dnaA-dnaN spacer regions. Moreover, they monitored the silent point mutations of the gyrA 95 and katG 463 genes. In a later study, metagenomics analysis was also carried out on a lung tissue 
sample taken from Terézia Hausmann, revealing the signs of a mixed infection, with the presence of two different M. tuberculosis strains (Chan et al., 2013). In 2015, samples of 26 Vác mummies were studied, extracted MTBC DNA was sequenced (Kay et al., 2015). Based on the sequencing results phylogenetic analysis was carried out. From eight individuals, 14 different $M$. tuberculosis genome sequences have been successfully determined. Furthermore, each infectious agent belongs to the M. tuberculosis lineage 4, which is represented in a high occurrence globally even today (Kay et al., 2015; Stucki et al., 2016).

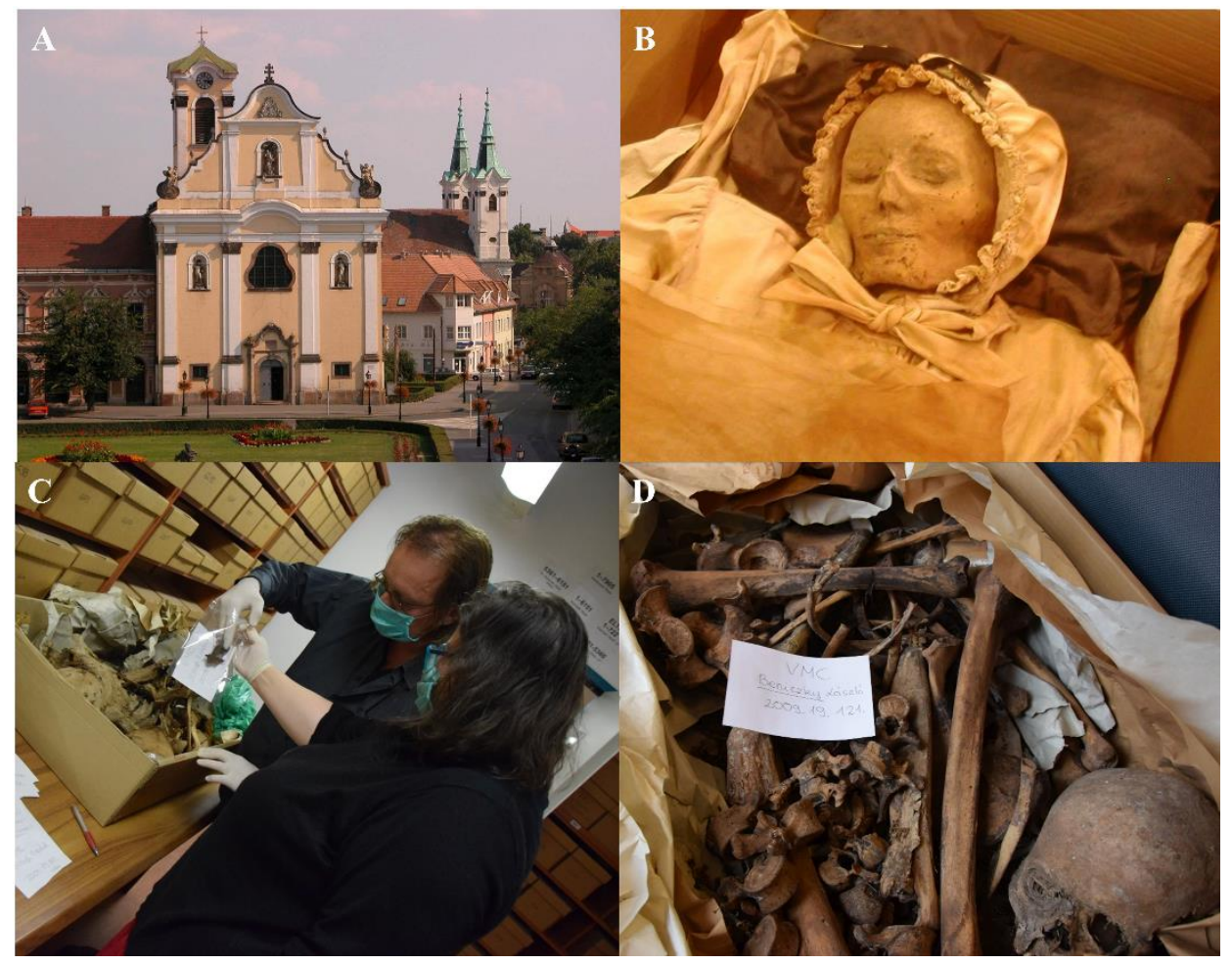

Figure 9: The source of the Vác mummies. A: The Dominican church of Vác. Photo: András Thumbasz B: The late Damiani Terézia (Body No: 79, Inv. No: 2009.19.79.) C: Sampling the Vác mummies for molecular biological investigation. D: The late László Beniczki (Body No: 121, Inv. No: 2009.19.121.) 


\section{AIMS AND OBJECTIVES}

Due to the vast burden caused by TB (WHO, 2020), this disease is still in the focus of research. With the emergence of MDR- and XDR-TB (extensively drug-resistant TB) strains the better understanding of evolutionary changes of the causative agent is surpassingly important. For a long time, paleopathology contributed to this aim with the macromorphological analysis of TB infected cases among past populations (e.g. Aufderheide \& Rodríguez-Martín, 1998; Marcsik et al., 1999, 2009; Pálfi \& Marcsik, 1999; Ortner, 2003; Maczel, 2003; Pálfi \& Molnár, 2009; Pálfi et al., 2012; Kajdocsi Lovász, 2015; Spekker et al., 2018; Spekker et al., 2020a; Spekker et al., 2020b). Most of the TB-related bony lesions are the result of extra-pulmonary TB, which was registered only in $16 \%$ of all incident cases in 2019 (WHO, 2020), thus to achieve a more accurate paleoepidemiological estimation of TB infected cases among past populations from the ' 90 s molecular biological and analytical methods started to be involved in the paleopathological studies, adapting clinical protocols (e.g. Spigelman \& Lemma, 1993; Salo et al., 1994; Taylor et al., 1999; Mays et al., 2001; Zink et al., 2001; Fletcher et al., 2003; Hershkovitz et al., 2008; Redman et al., 2009; Chan et al., 2013, Kay et al., 2015). The combined application of macroscopic, aDNA and lipid biomarker based methods resulted outstanding results (e.g. Donoghue et al., 1998; Gernaey et al., 1998; Hershkovitz et al., 2008; Donoghue et al., 2010; Lee et al., 2012; Baker et al., 2015; Lee et al., 2015; Masson et al., 2015; Minnikin et al., 2015; Molnár et al., 2015; Luna et al., 2020; Donoghue et al., 2017). As the aforementioned examples present, the lipid biomarker-based diagnostic methods, were proven to be efficient and reliable in numerous cases, hence we chose to optimise a similar method.

The most relevant detection method of mycolic acids from human archaeological samples was described by Hershkovitz and colleagues in 2008. The described process consists a very detailed sample pre-treatment. The initial lipid extraction is followed by two further solid phase extraction purification steps, as well as with a complex derivatisation protocol, which provides great sensitivity and specificity. The analysis of the purified MAs is carried out by an initial RP-HPLC separation, followed by the separation of MA types on NP-HPLC. The separated and collected MA types are further analysed in a final RP-HPLC measurement.

A different approach was also introduced in 2014 (Borowska-Strugińska et al., 2014). The method based on HPLC-MS/MS examination, with electrospray ionisation (ESI). Their 
analyses targeted 14 of the most characteristic MAs expressed in M. tuberculosis including representatives of $\alpha$-, methoxy- and ketomycolates. The targeted lipids were analysed in multiple reaction mode. As their protocol did not include any derivatisation and the samples were analysed by flow injection analyses, the established procedure was rapid.

For TB diagnosis on historical bone samples based on mycocerosates and C27 mycolipenic acid one method has been published so far (Redman et al., 2009). The extracted MC and ML containing fraction was initially derivatised with PFB and further extracted, followed by a NP-SPE purification. The collected fractions were analysed on NP-HPLC due to the separation of multimethyl-branched FA-PFB esters from other FA-PFB esters. The multimethyl-branched FA-PFB esters were collected and measured by NI-CI GC-MS in SIM mode.

Two of the above mentioned methods for the detection of MA, MC and ML C27 are used for a long time (Hershovitz et al., 2008; Redman et al., 2009; Lee et al., 2012; Donoghue et al., 2017) and proved their outstanding relevance in many cases, however they both include a very complex sample pre-treatment procedure.

Our aim was to establish a lipid biomarker based HPLC-MS method, for TB diagnosis in historical human samples, as this instrumentation is available in many laboratories, and has the potential of a quick and sensitive and at the same time affordable measurement protocol. The main objectives of this $\mathrm{PhD}$ dissertation are the following:

1. Development and optimisation of a HPLC-MS method for the detection of the two most commonly used lipid biomarkers, namely the mycolic acids and mycocerosic acids.

2. Development of a lipid profile library, regarding both mycolic and mycocerosic acids, which can be used as reference for diagnosis.

3. Testing the efficiency of the established lipid biomarker based method on a well-studied collection of mummified human remains. 


\section{MATERIALS AND METHODS}

\subsection{Materials}

\subsubsection{The used bacterial and human samples}

Two reference strains from the American Type Culture Collection (ATCC), provided by BEI Resources (Manassas, Virginia, USA), namely the M. tuberculosis H37Rv (NR-49098) and M. bovis (NR-31210) and MA standard provided by David E. Minnikin were used for primary verification. For the method testing, five M. tuberculosis complex strains were used (laboratory IDs of the isolated strains MTBC-1/2015; MTBC-254/2000; MTBC-3910/2014; MTBC-242/2000; and MTBC-1/8508/2014), isolated from patients diagnosed with pulmonary tuberculosis. Also, eight different NTM species, namely M. kansasii 1959/2018, M. chelonae 16/2018, M. gordonae 389/2018, M. intracellulare 7802/2017, M. avium 16229/2018, M. chimaera 619/2018, M. abscessus ssp. abscessus 180/2018, and M. fortuitum complex 3/2018, from various clinical specimens were included. The clinical samples were isolated in two laboratories, namely the Institute of Clinical Microbiology, University of Szeged, Szeged, Hungary and the National Korányi Institute of TB and Pulmonology, Budapest, Hungary, following the national recommendations (EMMI, State Secretariat for Healthcare, 2018) For the identification of the isolated strains commercially available tests were used following the instructions of the manufacturer, (MALDI-TOF mass spectrometry, Bruker/Hain Lifescience) and sequencing (Cepheid, Becton Dickinson) 16S rDNA, rpoB and $h s p 65$ sequence analysis). The strains were cultured on Löwenstein-Jensen medium (L-asparagine, monopotassium phosphate, magnesium sulfate, magnesium citrate, soluble potato starch, malachite green, whole eggs, glycerol and demineralized water) for 13 weeks, incubating at $37^{\circ} \mathrm{C}$. In case of adequate growth and pure culture, the strains were inoculated into fresh media and cultured for a further $1-3$ weeks at $37{ }^{\circ} \mathrm{C}$. The inactivation was carried out by heating for 4 hours in physiological saline solution and stored at $-20{ }^{\circ} \mathrm{C}$, after freeze-drying. For the method optimisation, $20 \mathrm{mg}$ of freeze-dried bacterial material was used.

\subsubsection{Historical samples used for testing the developed mycocerosic acid detection method}

For the test of the developed mycocerosic acid detection method bone and soft tissue samples were taken from six individuals, selected on the base of previous positive results gained by 
aDNA examination (Table 1). The sampled adult individuals were four females and two males. The analysed mummy samples (both bone and soft tissue samples) derived from the chest region of the examined individuals. The samples were removed by sanitized tweezers and stored in tightly closed bags separated well from each other at room temperature. The ribs have been powdered, while the soft tissues were processed in the clean laboratory of the Institute for Mummy Studies, EURAC Research, Bolzano, Italy.

\begin{tabular}{|c|c|c|c|c|c|}
\hline \multirow[t]{2}{*}{ Name } & \multirow{2}{*}{$\begin{array}{l}\text { Body } \\
\text { number }\end{array}$} & \multirow{2}{*}{$\begin{array}{l}\text { Inventory } \\
\text { number }\end{array}$} & \multirow{2}{*}{$\begin{array}{l}\text { Age at } \\
\text { death }\end{array}$} & \multicolumn{2}{|c|}{ Sample weight (mg) } \\
\hline & & & & $\begin{array}{l}\text { Bone } \\
\text { sample }\end{array}$ & $\begin{array}{l}\text { Soft tissue } \\
\text { sample }\end{array}$ \\
\hline $\begin{array}{l}\text { Terézia } \\
\text { Hausmann }\end{array}$ & $\# 68$ & 2009.19 .68 & 28 & 400 & 284 \\
\hline $\begin{array}{l}\text { Anna } \\
\text { Schneller }\end{array}$ & $\# 78$ & 2009.19.78. & 48 & 699 & 459 \\
\hline $\begin{array}{l}\text { Erzsébet } \\
\text { Virágh }\end{array}$ & \#80 & 2009.19 .80 & 37 & 500 & 193 \\
\hline $\begin{array}{l}\text { László } \\
\text { Beniczky }\end{array}$ & $\# 121$ & 2009.19.121. & $\sim 38$ & 500 & 482 \\
\hline $\begin{array}{l}\text { Gáspár } \\
\text { Steitel }\end{array}$ & \#25 & 2009.19.25. & 58 & 500 & 227 \\
\hline $\begin{array}{l}\text { Terézia } \\
\text { Damiani }\end{array}$ & $\# 79$ & 2009.19.79. & 37 & 519 & 257 \\
\hline
\end{tabular}

Table 1: Details of the examined individual mummies

\subsubsection{Solvents, chemicals and consumables and equipments used for measurements}

For the sample pre-treatment analytical grade methanol $(\mathrm{MeOH})$, toluene, hexane isomer mixture, ethyl acetate, petroleum ether, diethyl ether and methyl tert-butyl ether (MTBE) were obtained from Molar Chemicals Ltd. (Halásztelek, Hungary). For HPLC-MS measurements HPLC grade isopropanol (IPA), heptane, acetonitrile (ACN), chloroforme, acetic acid $(\mathrm{AcOH})$, formic acid and ammonium formate were ordered from the VWR International Ltd. (Debrecen, Hungary). The $\mathrm{KOH}, \mathrm{HCl}$ solution, and consumables including polytetrafluoroethylene (PTFE) capped glass tubes, PTFE capped vials, glass test tubes, and PTFE syringe filters (pore size: $2.0 \mu \mathrm{m}$; diameter: $13 \mathrm{~mm}$ ) were purchased also from VWR International Ltd. (Debrecen, Hungary). For the SPE purification Strata 18-E (55 
$\mu \mathrm{m}, 70$ A) cartridge was used (Phenomenex, Torrance, California, USA). The TLC Silica gel 60 plates were purchased from Merck Millipore (Burlington, Massachusetts, USA).

During the sample preparation Christ Alpha 1-4 freeze-dryer (Martin Christ Gefriertrocknungsanlagen GmbH, Harz, Germany) and Savant SC250EXP SpeedVac concentrator (Thermo Scientific, Waltham, Massachusetts, USA) were used for freezedrying and solvent evaporation, respectively. Measurements were carried out on a Shimadzu LC-10AD VP HPLC coupled with a Shimadzu LCMS-2010A Single Quadrupole mass spectrometer (MS) and on a Dionex Ultimate 3000 UHPLC system (Thermo Scientific, Waltham, Massachusetts, USA), which was coupled with a Q-Exactive Plus MS (Thermo Scientific, Waltham, Massachusetts, USA).

For the separation, a Gemini - NX C18 (3 $\mu \mathrm{m}, 110 \mathrm{~A}, 50 \mathrm{~mm}$ x $2 \mathrm{~mm}$ ) column (Phenomenex, Torrance, California, USA) was used.

\subsection{Methods}

\subsubsection{Optimisation of the mycolic acid detection method}

\subsubsection{Mycolic acid detection by single quadrupole LCMS}

The lipid extraction and purification was carried out following the previously published method by Hershkovitz and colleagues (2008) with the exclusion of derivatisation and simplification of the SPE purification, using the MTBC-1/2015 strain and MA standard. 20 mg of bacterial samples were heated at $100{ }^{\circ} \mathrm{C}$ overnight with $30 \% \mathrm{KOH}$ in $\mathrm{MeOH}(2 \mathrm{ml}$; $\mathrm{m} / \mathrm{V})$ and toluene $(1 \mathrm{ml})$ in PTFE capped glass tubes. The tubes were cooled and $10 \% \mathrm{HCl}$ $(1 \mathrm{ml})$ was added in an ice bath; the $\mathrm{pH}$ was finally set to 1 with the addition of $37 \% \mathrm{HCl}$ solution. Thereafter, toluene was added $(1 \mathrm{ml})$ to the samples and after $1 \mathrm{~min}$ of vortexing, they were centrifuged at $1200 \mathrm{rpm}$ for $15 \mathrm{~min}$. The upper organic layer was transferred into a new glass tube, while the bottom layer was re-extracted twice with the same method with the further addition of toluene. The collected and combined organic layer was washed with water $(1 \mathrm{ml})$. The collected and combined organic phases were evaporated to dryness in vacuum. The samples dissolved in minimal diethyl ether $(\sim 0.25 \mathrm{ml})$ and loaded on $500 \mathrm{mg} / 3 \mathrm{ml} \mathrm{C} 18$ cartridges.

Additional $0.1 \mathrm{ml}$ diethyl ether was used for rinsing the tubes. Details of the fractionation are discussed in Table 2. 


\begin{tabular}{|c|c|c|c|}
\hline & $\begin{array}{c}\text { Water } \\
(\mathbf{m l})\end{array}$ & $\begin{array}{c}\text { Methanol } \\
(\mathbf{m l})\end{array}$ & $\begin{array}{c}\text { Toluene } \\
(\mathbf{m l})\end{array}$ \\
\hline $\mathbf{1}$ & 1.6 & 4.4 & \\
\hline $\mathbf{2}$ & 0.5 & 5.5 & \\
\hline $\mathbf{3}$ & 0.5 & 5.5 & \\
\hline $\mathbf{4}$ & & 5.5 & 0.5 \\
\hline $\mathbf{5}$ & & 5.2 & 0.8 \\
\hline $\mathbf{6}$ & & 2 & 4 \\
\hline
\end{tabular}

Table 2: RP-SPE purification sequence

Collected fractions were dried in vacuum, and dissolved in diethyl ether for thin layer chromatography (TLC) (petroleum ether (bp 60-80 ${ }^{\circ} \mathrm{C}$ )/ethyl acetate (80:20)) analysis. For revealing lipids, 5\% ethanolic molybdophosphoric acid (MPA) stain was used, followed by drying with heat gun. RF values were compared to the ones gained from MA standard.

The fraction containing MAs was evaporated to dryness in vacuum and dissolved in $1 \mathrm{ml}$ chloroform for analysis carried out on Shimadzu LCMS-2010A. For the optimisation of the HPLC and MS settings $5 \mu 1$ samples were applied in flow injection analysis (FIA), with 200 $\mu \mathrm{l} / \mathrm{min}$ flow rate. The tested eluent compositions are shown in Table 3. Eluent A and eluent B were mixed in equal ratios. The initial settings of MS were the following: negative ion mode, the ionisation was electrospray ionisation (ESI), the targeted masses were monitored in scan mode, the nebuliser gas was air, curved desolvation line (CDL) and interface voltage were set to $-40 \mathrm{kV}$ and $3.5 \mathrm{kV}$ respectively. The tested eluent compositions are shown in Table 3.

\begin{tabular}{|c|c|c|}
\hline Eluent A & Eluent B & \\
\hline $\begin{array}{l}\mathrm{MeOH}: \mathrm{ACN}: \mathrm{CHCl}_{3}(2: 4: 4) \\
\quad+5 \mathrm{mM} \mathrm{NH}_{4} \mathrm{COOH}\end{array}$ & - & 1 \\
\hline $\begin{array}{l}\text { MeOH:ACN (8:2) } \\
+5 \mathrm{mM} \mathrm{NH}_{4} \mathrm{COOH}\end{array}$ & $\begin{array}{l}\text { IPA:MeOH:ACN (50:20:30) } \\
\quad+5 \mathrm{mM} \mathrm{NH}_{4} \mathrm{COOH}\end{array}$ & 2 \\
\hline $\begin{array}{l}\text { MeOH:ACN (8:2) } \\
+5 \mathrm{mM} \mathrm{NH}_{4} \mathrm{COOH}\end{array}$ & $\begin{array}{c}\text { IPA:MeOH: } \mathrm{CHCl}_{3}(50: 30: 20)+ \\
5 \mathrm{mM} \mathrm{NH}_{4} \mathrm{COOH}\end{array}$ & 3 \\
\hline $\begin{array}{l}\text { MeOH:ACN (8:2) } \\
+5 \mathrm{mM} \mathrm{NH}_{4} \mathrm{COOH}\end{array}$ & $\begin{array}{l}\text { IPA: } \mathrm{MeOH}: \mathrm{CHCl}_{3}(50: 49: 1) \\
\quad+5 \mathrm{mM} \mathrm{NH}_{4} \mathrm{COOH}\end{array}$ & 4 \\
\hline $\begin{array}{l}\text { MeOH:ACN (8:2) } \\
+5 \mathrm{mM} \mathrm{NH}_{4} \mathrm{COOH}\end{array}$ & $\begin{array}{l}\text { IPA:MeOH: } \mathrm{CHCl}_{3}(50: 45: 5) \\
\quad+5 \mathrm{mM} \mathrm{NH}_{4} \mathrm{COOH}\end{array}$ & 5 \\
\hline
\end{tabular}

Table 3: Eluent compositions tested on single quadrupole HPLC-MS 
For the preliminary measurements 2 representatives of each MA types were chosen as target molecules. Details of the targeted mycolic acids are shown in Table 4.

\begin{tabular}{|c|c|c|}
\hline $\boldsymbol{m} / \boldsymbol{z}$ & Elemental composition & Abbreviation \\
\hline $\mathbf{1 1 6 4 . 2}$ & $\alpha-\mathrm{C}_{80} \mathrm{H}_{156} \mathrm{O}_{3}$ & $\alpha-\mathrm{C} 80$ \\
\hline $\mathbf{1 1 9 2 . 2}$ & $\alpha-\mathrm{C}_{82} \mathrm{H}_{160} \mathrm{O}_{3}$ & $\alpha-\mathrm{C} 82$ \\
\hline $\mathbf{1 2 5 2 . 3}$ & $\mathrm{m}-\mathrm{C}_{85} \mathrm{H}_{168} \mathrm{O}_{4}$ & $\mathrm{~m}-\mathrm{C} 85$ \\
\hline $\mathbf{1 2 6 4 . 3}$ & $\mathrm{k}-\mathrm{C}_{86} \mathrm{H}_{168} \mathrm{O}_{4}$ & $\mathrm{k}-\mathrm{C} 86$ \\
\hline $\mathbf{1 2 7 8 . 3}$ & $\mathrm{k}-\mathrm{C}_{87} \mathrm{H}_{170} \mathrm{O}_{4}$ & $\mathrm{k}-\mathrm{C} 87$ \\
\hline $\mathbf{1 2 8 0 . 3}$ & $\mathrm{m}-\mathrm{C}_{87} \mathrm{H}_{172} \mathrm{O}_{4}$ & $\mathrm{~m}-\mathrm{C} 87$ \\
\hline
\end{tabular}

Table 4: Details of the targeted mycolic acids for single quadrupole measurements

During the optimisation of the MS settings air and nitrogen as nebuliser gasses, different interface and CDL voltages were tested. The efficiency of selected ion monitoring a scan mode was compared, as well.

\subsubsection{Mycolic acid detection by Q-Exactive Plus Orbitrap MS}

After the preliminary measurements the mycolic acid detection was transferred to a more sensitive equipment, namely to a Dionex Ultimate 3000 UHPLC coupled with a Q-Exactive Plus mass spectrometer. The initial eluent composition consisted MeOH:ACN (80:20) as eluent A, which was supplemented with $5 \mathrm{mM}$ ammonium-formate, and IPA: $\mathrm{MeOH}: \mathrm{CHCl}_{3}$ (50:45:5) supplemented with $5 \mathrm{mM}$ ammonium-formate as eluent B. For the measurements FIA was applied, and the elution was carried out with $50 \%$ eluent B on $200 \mu \mathrm{l} / \mathrm{min}$ flow rate. Samples were dissolved in $1 \mathrm{ml}$ chloroform and $5 \mu 1$ was injected for analysis. For ionisation ESI was used, and the ions were monitored in negative ion mode. 


\begin{tabular}{|c|c|c|}
\hline $\boldsymbol{m} / \boldsymbol{z}$ & Elemental composition & Abbreviation \\
\hline $\mathbf{1 1 3 6 . 1 6 5 6 8}$ & $\alpha-\mathrm{C}_{78} \mathrm{H}_{152} \mathrm{O}_{3}$ & $\alpha-\mathrm{C} 78$ \\
\hline $\mathbf{1 1 6 4 . 1 9 6 7 7}$ & $\alpha-\mathrm{C}_{80} \mathrm{H}_{156} \mathrm{O}_{3}$ & $\alpha-\mathrm{C} 80$ \\
\hline $\mathbf{1 1 9 2 . 2 2 7 9 7}$ & $\alpha-\mathrm{C}_{82} \mathrm{H}_{160} \mathrm{O}_{3}$ & $\alpha-\mathrm{C} 82$ \\
\hline $\mathbf{1 2 2 0 . 2 6 0 8 9}$ & $\alpha-\mathrm{C}_{84} \mathrm{H}_{164} \mathrm{O}_{3}$ & $\alpha-\mathrm{C} 84$ \\
\hline $\mathbf{1 2 3 6 . 2 5 7 0 9}$ & $\mathrm{k}-\mathrm{C}_{84} \mathrm{H}_{164} \mathrm{O}_{4}$ & $\mathrm{k}-\mathrm{C} 84$ \\
\hline $\mathbf{1 2 5 2 . 2 8 4 2 3}$ & $\mathrm{m}-\mathrm{C}_{85} \mathrm{H}_{168} \mathrm{O}_{4}$ & $\mathrm{~m}-\mathrm{C} 85$ \\
\hline $\mathbf{1 2 6 4 . 2 8 7 5 5}$ & $\mathrm{k}-\mathrm{C}_{86} \mathrm{H}_{168} \mathrm{O}_{4}$ & $\mathrm{k}-\mathrm{C} 86$ \\
\hline $\mathbf{1 2 7 8 . 3 0 2 8 8}$ & $\mathrm{k}-\mathrm{C}_{87} \mathrm{H}_{170} \mathrm{O}_{4}$ & $\mathrm{k}-\mathrm{C} 87$ \\
\hline $\mathbf{1 2 8 0 . 3 1 4 0 9}$ & $m-\mathrm{C}_{87} \mathrm{H}_{172} \mathrm{O}_{4}$ & $\mathrm{~m}-\mathrm{C} 87$ \\
\hline $\mathbf{1 2 9 2 . 3 1 7 3 1}$ & $\mathrm{k}-\mathrm{C}_{88} \mathrm{H}_{172} \mathrm{O}_{4}$ & $\mathrm{k}-\mathrm{C} 88$ \\
\hline $\mathbf{1 2 9 4 . 3 3 2 0 9}$ & $m-\mathrm{C}_{88} \mathrm{H}_{174} \mathrm{O}_{4}$ & m-C 88 \\
\hline $\mathbf{1 3 0 8 . 2 6 4 3 2}$ & $m-\mathrm{C}_{89} \mathrm{H}_{176} \mathrm{O}_{4}$ & m-C 89 \\
\hline
\end{tabular}

Table 5: Details of the targeted mycolic acids for Orbitrap measurements

The detection was carried out in scan mode. The maximum mass deviation of the targeted $[\mathrm{M}-\mathrm{H}]^{-}$ions was $5 \mathrm{ppm}$ for peak identification. Details of the targeted MAs are in Table 5, which were chosen on the base of a previously published HPLC-MS/MS method (BorowskaStrugińska et al., 2014). For further verification of the observed peaks ions were fragmented in parallel reaction monitoring (PRM) with the application of collision energy of $70 \mathrm{kV}$.

Further variations of eluent compositions were tested including the fine tuning of the chloroform concentration (from $0 \%$ to $40 \%$ ), along with examination of the effect of $\mathrm{AcOH}$ and formic acid on the efficiency of the ionisation (Table 6). 


\begin{tabular}{|c|c|c|}
\hline Eluent A & Eluent B (1-4) & \\
\hline \multirow{4}{*}{$\begin{array}{l}\text { MeOH:ACN (8:2) } \\
+5 \mathrm{mM} \mathrm{NH}_{4} \mathrm{COOH}\end{array}$} & $\begin{array}{l}\mathrm{MeOH}: \mathrm{ACN} \mathrm{CHCl}_{3} \quad(2: 4: 4) \\
+5 \mathrm{mM} \mathrm{NH}{ }_{4} \mathrm{COOH}\end{array}$ & 1 \\
\hline & $\begin{array}{l}\text { IPA:MeOH: } \mathrm{CHCl}_{3} \\
(50: 30: 20)+\quad+\quad 5 \mathrm{mM} \\
\mathrm{NH}_{4} \mathrm{COOH}\end{array}$ & 2 \\
\hline & $\begin{array}{l}\text { IPA:MeOH: } \mathrm{CHCl}_{3} \quad(50: 45: 5) \\
+5 \mathrm{mM} \mathrm{NH}_{4} \mathrm{COOH}\end{array}$ & 3 \\
\hline & $\begin{array}{l}\text { IPA:MeOH: } \mathrm{CHCl}_{3} \quad(50: 49: 1) \\
+5 \mathrm{mM} \mathrm{NH}_{4} \mathrm{COOH}\end{array}$ & 4 \\
\hline
\end{tabular}

Table 6: Eluent compositions for the optimisation of $\mathrm{CHCl}_{3}$ concentration

In the case of MS settings, spray and S-lens voltage, capillary and auxiliary gas temperature were optimised, while the sheath gas flow and the auxiliary gas rates were constant at 15 $1 / \mathrm{min}$ and $101 / \mathrm{min}$, respectively. The detection was carried out in scan mode.

After optimising a basic detection method for mycolic acids the pre-treatment process was further simplified by the exclusion of SPE purification, and the extraction protocol was optimised. First the efficiency of the application of $10 \%(\mathrm{~m} / \mathrm{V}), 20 \%(\mathrm{~m} / \mathrm{V}), 30 \%(\mathrm{~m} / \mathrm{V})$ $\mathrm{KOH}$ was tested along with the comparison of toluene and hexane isomer mixture as extraction solvent. Afterwards, with the best $\mathrm{KOH}$ concentration further extraction solvents were taken under investigation with the following compositions: extraction 3 times with petroleum ether $\left(60-80{ }^{\circ} \mathrm{C} \mathrm{bp}\right)$, followed by pooling the extracted organic layers; extraction 3 times with toluene and 1 time with hexane isomer mixture, followed by pooling the extracted organic layers; extraction 3 times with toluene and 1 time with petroleum ether $\left(60-80{ }^{\circ} \mathrm{C} \mathrm{bp}\right)$, followed by pooling the extracted organic layers; and extraction 1 time with MTBE, 1 time with hexane isomer mixture and 1 time with petroleum ether $\left(60-80^{\circ} \mathrm{C} \mathrm{bp}\right)$, followed by pooling the extracted organic layers.

With the final method the bacterial MA profiles were established. For the profiling additional MAs were involved, which are included in the 5. Table. The area values of the monitored MAs were summarised in the case of each bacterial samples and then given in percent form.

\subsubsection{Mycocerosic acid separation and detection by Q-Exactive Plus Orbitrap MS}

The samples were heated at $100{ }^{\circ} \mathrm{C}$ overnight with $20 \% \mathrm{KOH}$ in $\mathrm{MeOH}(2 \mathrm{ml} ; \mathrm{m} / \mathrm{V})$ and toluene $(1 \mathrm{ml})$ in PTFE capped glass tubes; for bacterial samples, $20 \mathrm{mg}$ was used. The tubes 
were cooled and $10 \% \mathrm{HCl}(1 \mathrm{ml})$ was added in an ice bath; the $\mathrm{pH}$ was finally set to 1 with the addition of $37 \% \mathrm{HCl}$ solution. Thereafter, toluene was added $(1 \mathrm{ml})$ to the samples and after $1 \mathrm{~min}$ of vortexing, they were centrifuged at $1200 \mathrm{rpm}$ for $15 \mathrm{~min}$. The organic layer was transferred into a new glass tube, while the bottom layer was re-extracted twice with the same method with the further addition of toluene and one more time with hexane $(1 \mathrm{ml})$. The collected and combined organic phases were evaporated to dryness in vacuum, and dissolved in $1000 \mu 1$ and $200 \mu 1$ isopropanol (IPA):heptane:ACN (4:1:5) in the case of bacterial and mummy samples, respectively. The sample solutions were filtered by PTFE syringe filters (pore size: $2.0 \mu \mathrm{m}$; diameter: $13 \mathrm{~mm}$ ).

The measurements were carried out on a Dionex Ultimate 3000 UHPLC system (Thermo Scientific, Waltham, Massachusetts, USA), which was coupled with a Q-Exactive Plus (Thermo Scientific, Waltham, Massachusetts, USA) mass spectrometer (MS). For the separation of the used crude extract, a Gemini - NX C18 ( $3 \mu \mathrm{m}, 110 \mathrm{~A}, 50 \mathrm{~mm} \times 2 \mathrm{~mm})$ column (Phenomenex, Torrance, California, USA) was used at $30{ }^{\circ} \mathrm{C}$. The eluent A was $\mathrm{ACN}$, containing $0.1 \% \mathrm{AcOH}$, while eluent $\mathrm{B}$ consisted of IPA:heptane (8:2), also supplemented with $0.1 \% \mathrm{AcOH}$. The flow rate was $200 \mu \mathrm{l} / \mathrm{min}$ and the applied gradient elution was the following: at $0 \min 10 \% \mathrm{~B}, 5 \min 15 \% \mathrm{~B}, 15 \min 70 \% \mathrm{~B}, 16 \min 90 \% \mathrm{~B}, 18$ $\min 90 \%$ B, $18.5 \min 20 \%$ B, $19.5 \min 20 \%$ B, $20 \min 90 \%$ B, $23 \min 90 \%$ B, $24 \min 10 \%$ $\mathrm{B}$ and $28 \mathrm{~min} 10 \% \mathrm{~B}$. The injection volume was $10 \mu \mathrm{l}$. The injection needle was thoroughly washed, before and after injection, with $150 \mu \mathrm{l}$ IPA:heptane (8:2). Solvent blank injections were made between each sample investigation. The MCs were monitored in negative Selected Ion Monitoring (SIM) mode. Details of the targeted MCs are shown in Table 7, their chemical structures are shown on Figure 10.

\begin{tabular}{|c|c|c|}
\hline $\mathbf{m} / \mathbf{z}$ & Elemental composition & Abbreviation \\
\hline $\mathbf{4 0 9 . 4 0 5 1 0}$ & $\mathrm{C}_{27} \mathrm{H}_{53} \mathrm{O}_{2}$ & $\mathrm{C} 27$ \\
\hline $\mathbf{4 3 7 . 4 3 6 4 0}$ & $\mathrm{C}_{29} \mathrm{H}_{57} \mathrm{O}_{2}$ & $\mathrm{C} 29$ \\
\hline $\mathbf{4 5 1 . 4 5 2 0 5}$ & $\mathrm{C}_{30} \mathrm{H}_{59} \mathrm{O}_{2}$ & $\mathrm{C} 30$ \\
\hline $\mathbf{4 7 9 . 4 8 3 3 5}$ & $\mathrm{C}_{32} \mathrm{H}_{63} \mathrm{O}_{2}$ & $\mathrm{C} 32$ \\
\hline $\mathbf{4 9 3 . 4 9 9 0 0}$ & $\mathrm{C}_{33} \mathrm{H}_{65} \mathrm{O}_{2}$ & $\mathrm{C} 33$ \\
\hline
\end{tabular}

Table 7: Details of the targeted mycocerosic acids 


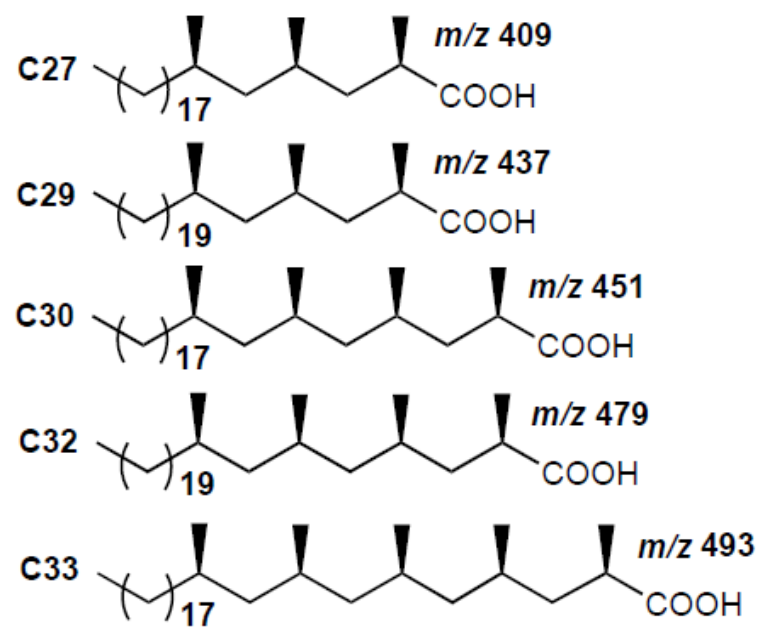

Figure 10: Chemical structure of the monitored mycocerosic acids

Initially the APCI and ESI ion sources were compared, along with the optimisation of the Slens voltage, the capillary and the auxiliary gas/vaporiser temperature. The sheath gas flow and the auxiliary gas rates were constant at $35 \mathrm{l} / \mathrm{min}$ and $10 \mathrm{l} / \mathrm{min}$, respectively.

The area values of the MC peaks were calculated with TraceFinder 4.0 General Quan Software (Thermo Scientific, Waltham, Massachusetts, USA). The maximum mass deviation from the calculated $[\mathrm{M}-\mathrm{H}]^{-}$ion mass was $5 \mathrm{ppm}$ for peak identification. For establishing MC profiles and for the evaluation of the analysed mummy samples, the detected MC peaks have been normalised to the peak with the highest area value. 


\section{RESULT AND DISCUSSIONS}

\subsection{Optimisation of the mycolic acid detection method}

The mass spectrometric detection of MAs can be carried out with several approaches, using matrix-assisted laser desorption/ionization-time of flight MS (MALDI-TOFMS), MALDI spiral-TOFMS, HPLC-ESI-QTOF MS, HPLC triple quadrupole MS/MS, HPLC- triple quadrupole/ion trap MS, HPLC-ESI/APCI-TOF MS (Laval et al., 2001; Song et al., 2009; Bhamidi et al., 2011; Shui et al., 2011; Szewczyk et al., 2013; Teramoto et al., 2015; Yoshino et al., 2019). However, the method optimisation started on a Shimadzu LCMS-2010A system, in the second half of the method development our laboratory improved its available facilities and we had the chance to continue our work on a HPLC-Orbitrap MS.

\subsubsection{Mycolic acid detection by single quadrupole LCMS}

Initially, the effect of five different eluent compositions was tested on the Shimadzu LCMS2010A system with the application of FIA (Table 3). The main difference of the eluents was the $\mathrm{CHCl}_{3}$ concentration, with the first containing the highest amount (40\%) and the second not containing any. The $3^{\text {rd }}, 4^{\text {th }}$ and $5^{\text {th }}$ tested eluent contained $10 \%, 0.5 \%$ and $2.5 \% \mathrm{CHCl}_{3}$, respectively. For the analysis MA standard provided by David E. Minnikin was used. With the first solvent mixture most of the monitored MAs with the expected $[\mathrm{M}-\mathrm{H}]^{-}$values were already observed, with the exception of the k-C86 MA (Figure 11.1). The application of the second eluent variation resulted the appearance of the same peaks, however their calculated area value was at least ten times smaller, compared to the previous results (Figure 11.2). The third eluent composition provided the best intensity and all the monitored MAs were observed, although even in this case the gained intensity growth was ranging between $10 \%$ and 30\%, depending on the targeted MA (Figure 11.3). The fourth and fifth variations resulted similar area values compared to the first one, but all the monitored MAs were detected (Figure 11.4;5). Although the highest intensity was provided by the third mixture, for further analysis the fifth one was chosen, as its efficiency was only slightly behind, but with a 7.5\% lower chloroform concentration (Figure 11). The application of non-polar solvents is widespread in HPLC-MS based MA detection methods, which is most commonly chloroform, but some methods are including hexane due to its even lower polarity (Bhamidi et al., 2011; Shui et al., 2011; Szewczyk et al., 2013; Borowska-Strugińska et al., 2014; Portevin et al., 2014). As our results represent as well they are beneficial for the ionisation of MAs. 


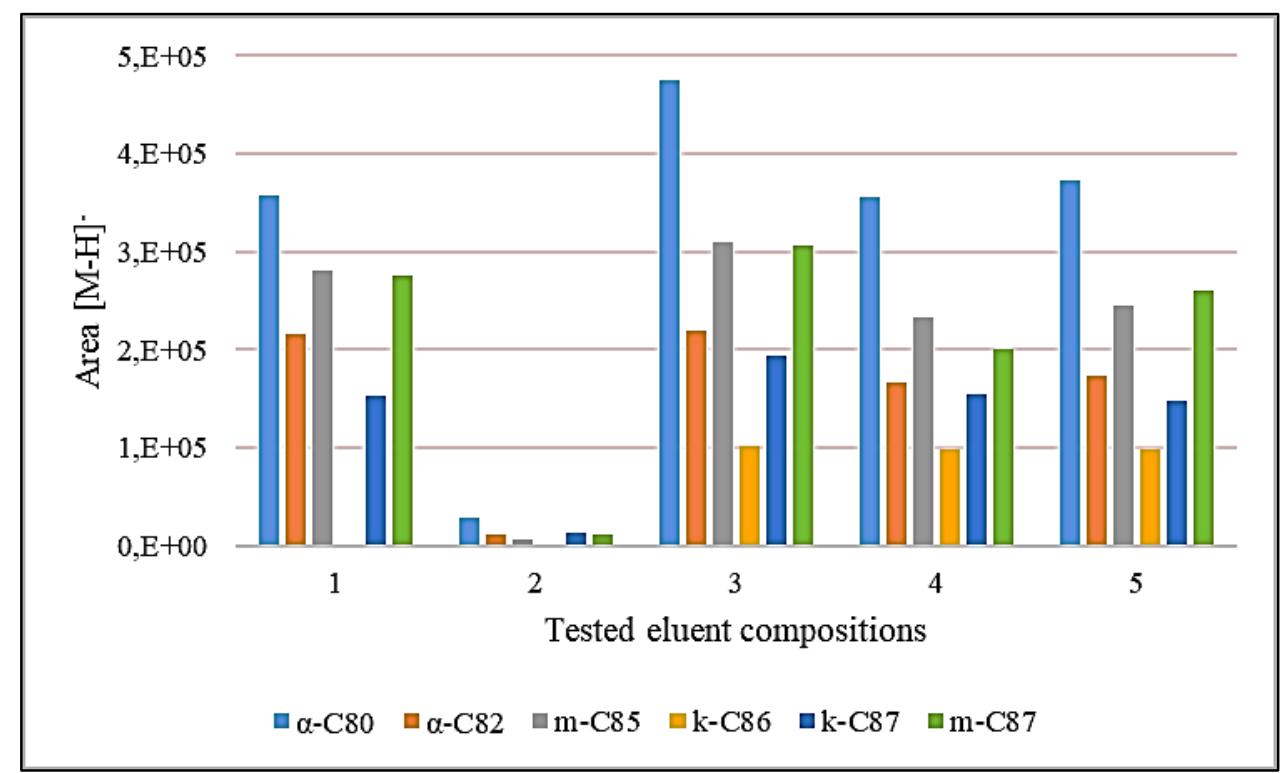

Figure 11: Comparison of the effect of 5 different eluent composition on the detection of MAs

A specific feature of the Shimadzu LCMS-2010A system is, that it provides the option of the application different nebuliser gasses, hence the next step was to test whether air or nitrogen is the more suitable nebuliser gas for the ionisation of MAs. As it can be seen on Figure 12, application of air provided better results, the area values were at least 6 times larger.

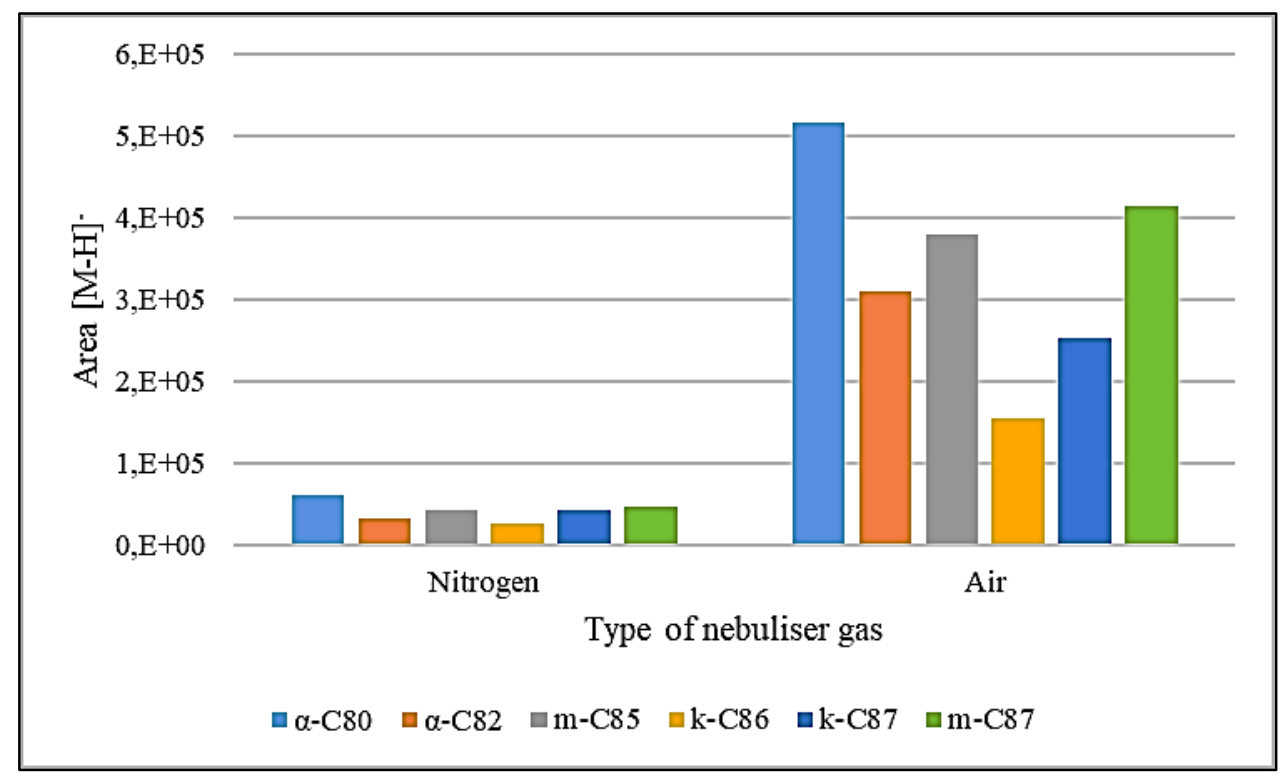

Figure 12: Comparison of the effect of nitrogen and air as nebuliser gas on the detection of MAs

The CDL voltage was also fine-tuned, values from 0 to $-100 \mathrm{~V}$ have been tested. The decrease of this value resulted only slight difference in every cases (Figure 13). The default setting $(-25 \mathrm{~V})$ provided the highest area values in the case of the monitored $\alpha$-MAs, although 
the ionisation of keto- and metoxymycolates were more efficient at $-40 \mathrm{~V}$, as a $10 \%$ increase was achieved. Keto- and metoxymycolates are least abundant in M. tuberculosis, compared to $\alpha$-MAs (Takayama et al., 2005), hence the $-40 \mathrm{~V}$ CDL voltage has been chosen for further application.

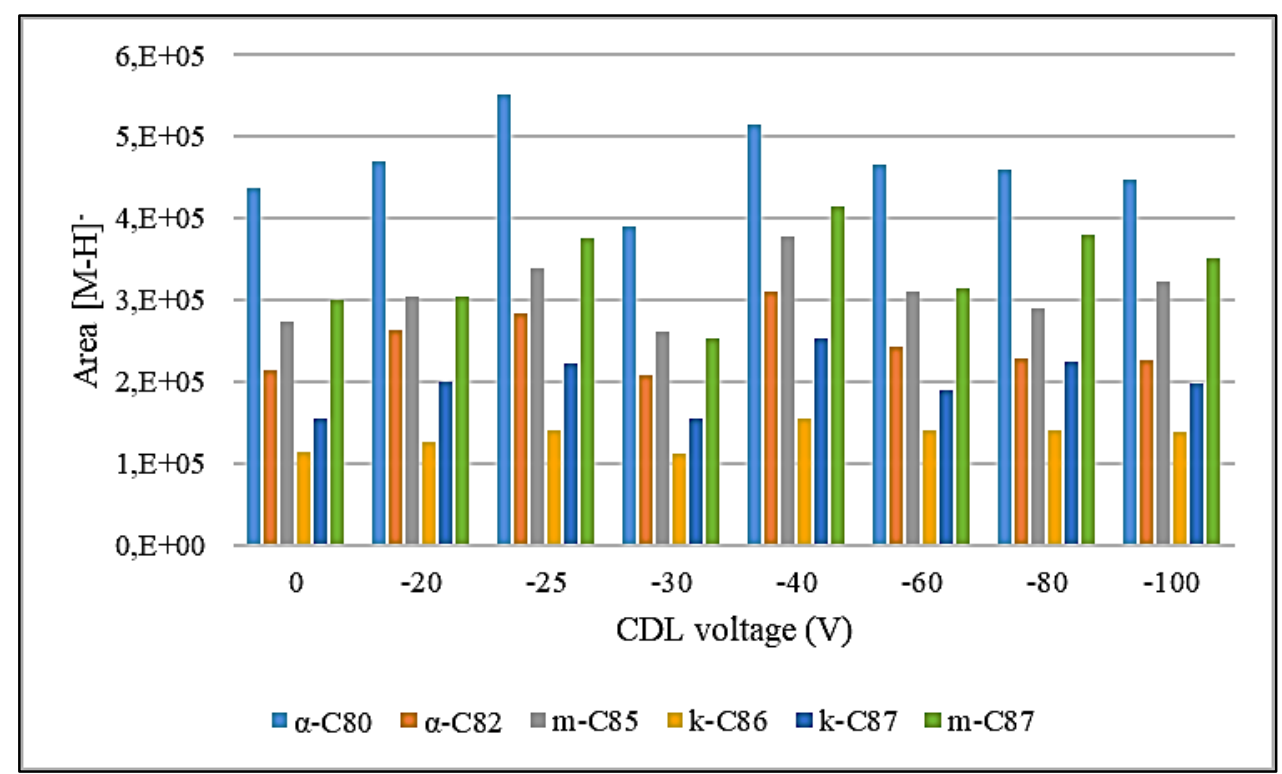

Figure 13: Optimisation of CDL voltage for the detection of MAs

The effect of changed interface voltage was also tested, starting from the basic tune setting, $3.5 \mathrm{kV}$. The interface voltage was increased up to $5 \mathrm{kV}$ with $0.5 \mathrm{kV}$ steps. A slight, $20-30 \%$ increase was observed in the case of all monitored MAs at $4 \mathrm{kV}$ and $4.5 \mathrm{kV}$ (Figure 14). With the application of $5 \mathrm{kV}$ the area values were similar to the initially measured ones. For further analysis, $4.5 \mathrm{kV}$ interface voltage was chosen. 


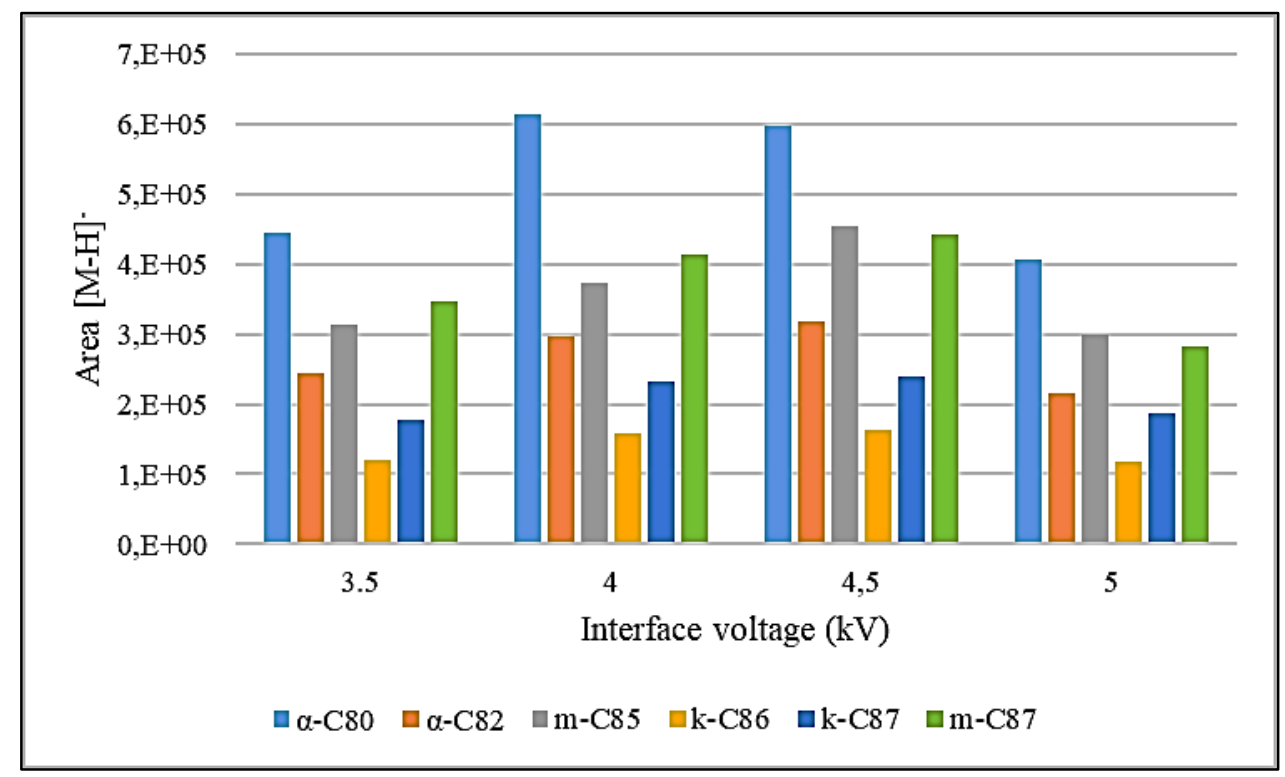

Figure 14: Optimisation of interface voltage for the detection of MAs

SIM and scan detection modes were also compared. Interestingly, detection in scan mode seemed scarcely more efficient (Figure 15).

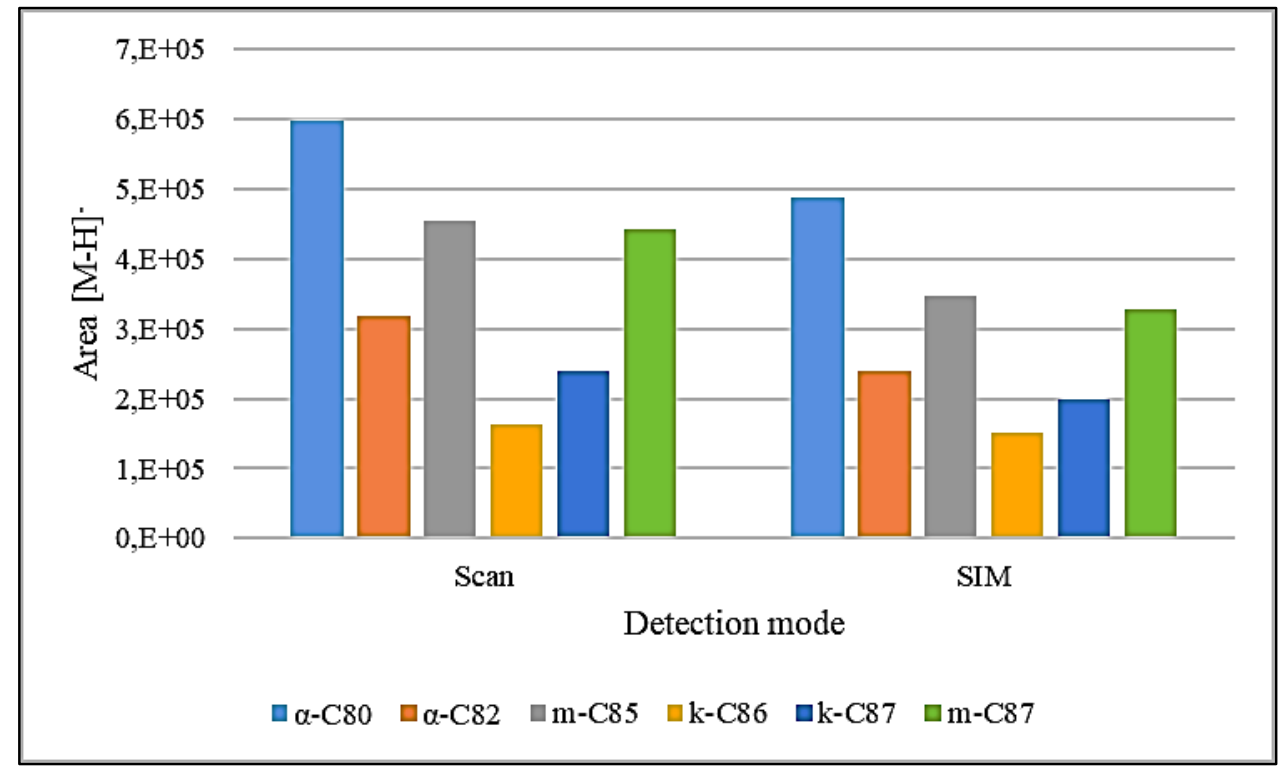

Figure 15: Comparison of Scan and SIM mode for MA detection

\subsubsection{Mycolic acid detection by Q-Exactive Plus Orbitrap MS}

6.1.2.1 Optimisation of a basic detection method and the identitfication of the targeted peaks

The optimisation of the MA detection method on a new, more sensitive equipment has been started by setting a basic detection method. Beside the great sensitivity provided by this equipment, other advantageous features of the Orbitrap MS are, that it enables MS/MS 
analysis, and the collected data are more prompt due to its high resolution. Initially, the eluents composition, optimised in the preliminary measurements $(50 \%$ eluent $\mathrm{A}$ : MeOH:ACN (8:2) + 5mM NH $4 \mathrm{COOH} ; 50 \%$ eluent B: IPA:MeOH:CHCl 3 (50:45:5) + 5mM $\mathrm{NH}_{4} \mathrm{COOH}$ ) was used. The basic setting of the capillary voltage was $3 \mathrm{kV}$, which was first increased to $3.2 \mathrm{kV}$, resulting approximately 3 times higher area values in the case of the monitored MAs (Figure 16 MA01-MA02). As setting the capillary voltage up to $4 \mathrm{kV}$ implied only a slight increase in the area values, further changes were not applied (Figure 16 MA02-MA03). The temperature of the capillary was increased to $350{ }^{\circ} \mathrm{C}$, from $300{ }^{\circ} \mathrm{C}$, resulting almost 1.5 times higher area values of the targeted lipids (Figure 16 MA03-MA04). Increasing the S-lens voltage from 50V to $70 \mathrm{~V}$ provided a similar result (Figure 16 MA04MA05), however further increase to $90 \mathrm{~V}$ resulted only a $10 \%$ raise of the area values. Due to the applied optimisation steps the intensity of C78-C86 MAs become 9-10 times higher, while the intensity of C87-C89 MAs increased with 300\%. The application of different nebuliser gas was not possible in the case of this equipment, as it was designed to operate only with high purity (99\%) nitrogen gas.

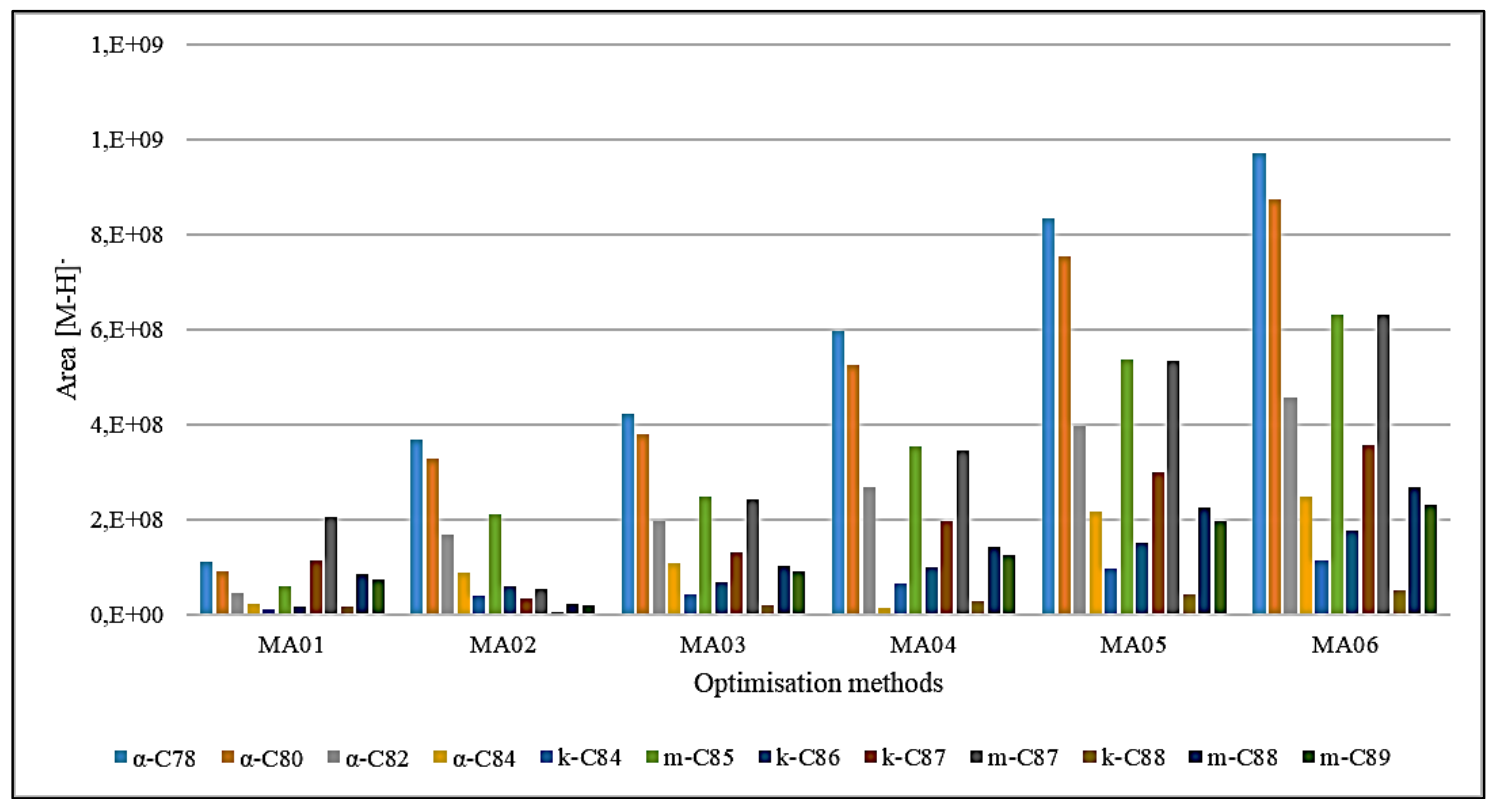

Figure 16: Optimisation of MS setting for a basic MA detection method

The identities of the targeted peaks were verified with two different methods. Beside finding the selected targeted peaks (Table 5), further MAs have been detected in the cases of all the three MA classes (Figure 17), and both the targeted and not targeted MAs presented 28 Dalton differences (two-carbon unit), characteristic to the homologous series of MAs, due to their biosynthesis pathway (Figure 17) (Takayama et al., 2005). The same MAs have been 
also analysed by other mass spectrometric investigations published carried out via triple quadrupole analysator (Szewczyk et al., 2013; Borowska-Strugińska et al., 2014; Song et al., 2009) and MALDI-TOF analysis (Teramoto et al., 2015; Yoshino et al., 2019), however in the latter case MAs were observed as $\mathrm{Na}^{+}$adducts due to the laser mediated ionisation.

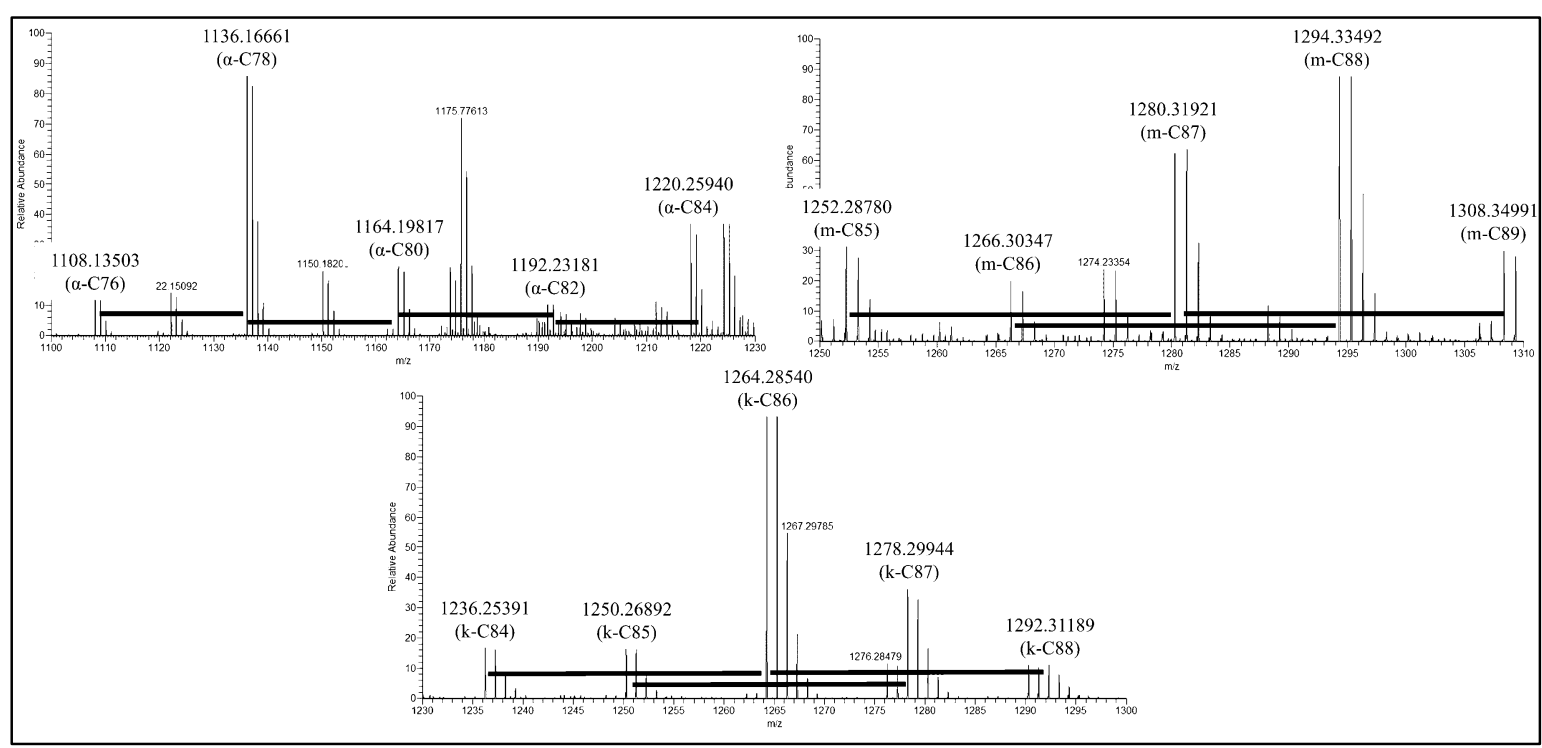

Figure 17: Examples of homolgous $\alpha$-, methoxy- and keto-MA series

PRM measurements were also carried out on the MA standard provided by David E. Minnikin. The two most characteristic fragments were the 365.35767 and the 395.38901, identified as the C24 and C26 $\alpha$-alkyl chain, respectively (Figure 18). The overall representation of 395.38901 fragment was approximately 7 times higher compared to 365.35767 in our measurements. These fragments have been observed by other authors, as well, with the application of triple quadrupole MS (Szewczyk et al., 2013; Song et al., 2009), qTOF MS (Bhamidi et al., 2011) and CID-MS (Lehmann et al., 2018). Szewczyk and colleagues (2013) included two MAs in their analysis which was represented among the MRM pairs with both containing C26 and C24 $\alpha$-alkyl chains, namely the $\alpha$-C78 and mC85. The intensity of the 395.38901 fragment was 5 times higher in both cases. The results of Song and colleagues (2009), Bhamidi and colleagues (2011) and Lehmann and colleagues (2018) also suggested a much higher contribution of MAs with C26 $\alpha$-alkyl chains among the analysed MTBC specimens. Fragments with 377.37360 and the $349.34717 \mathrm{~m} / \mathrm{z}$ value were also detected, which were interpreted previously by Szewczyk and colleagues (2013) as the result of $\mathrm{H}_{2} \mathrm{O}$ loss of the $\mathrm{C} 24$ and $\mathrm{C} 26 \alpha$-alkyl chains, respectively. One additional fragment should be also notified, detected at $\mathrm{m} / \mathrm{z} 381.37360$, which was also included in the proposed fragmentation pattern of the previously referred authors, suggested to be a 
preserved fragment after the loss of the carboxyl-group and the meromycolic chain, C24 and C26 $\alpha$-alkyl chain, respectively (Figure 18). The fragmentation was carried out with the application of $80 \mathrm{~V}$ collision energy, however according to the literature a broad range of voltage can be applied. Song and colleagues (2009) applied $55 \mathrm{eV}$ to initiate collision induced dissociation. Bhamidi and colleagues (2011) used two approaches for MA detection, in the case of HPLC-ESI/APCI-TOF MS measurements, $120 \mathrm{~V}$ fragmentor voltage was applied, while for the analysis of the $\alpha$-alkyl chains MS/MS measurements were carried out on a qTOF detector with the application of $75 \mathrm{eV}$ for the fragmentation. For the description of a very detailed fragmentation pattern Szewczyk and colleagues (2013) applied unique collision energy for each targeted MA ranging from 74 to $88 \mathrm{eV}$.

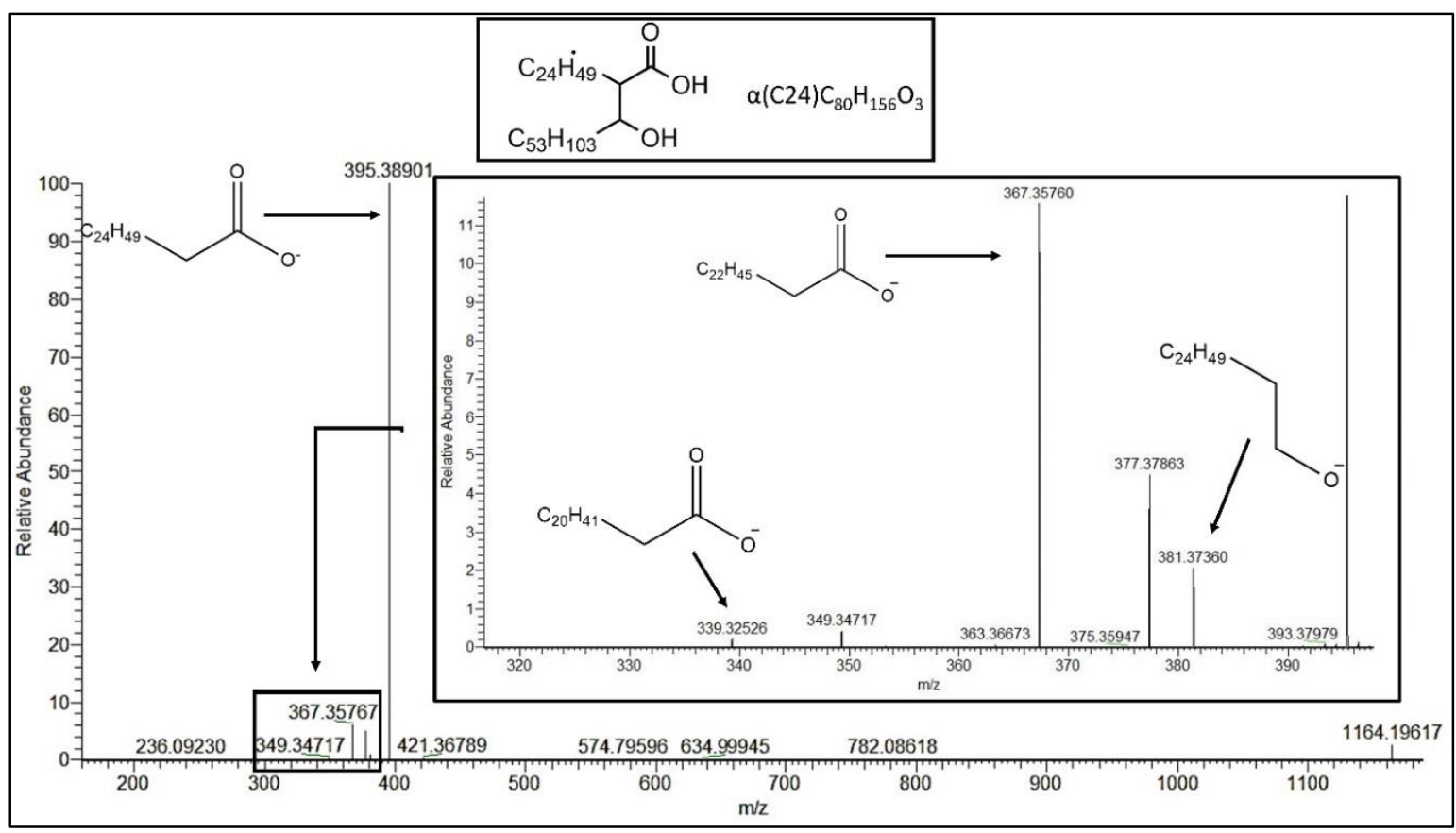

Figure 18: Schematic MA fragmentation pattern ( $\alpha-\mathrm{C80}$ drawn as example)

After verifying the observed peaks, MAs extracted from clinical samples (M. tuberculosis $1 / 2015$ ) was used for the further measurements, due to the difficulty of obtaining commercial MA standard.

6.1.2.2 Optimisation of chloroform concentration of the eluent composition and MS settings

The ratio of chloroform in the eluent was also fine-tuned on our HESI ion source. Nine eluent variations were tested, within the chloroform ratio ranging from 0 to $40 \%$ (Table 6). The eluent compositions (50\% eluent B-3) presenting $2.5 \%$ of higher $\mathrm{CHCl}_{3}$ ratio provided relatively low area values (Figure 19). The lowest area values were recorded in the presence 
of $5 \%$ chloroform (100\% eluent $\mathrm{B}-3$ ). Increasing the $\mathrm{CHCl}_{3}$ ratio in the eluent resulted increased area values in the case of $10 \%$ (50\% eluent B-2), $20 \%$ (100\% eluent B-2), $30 \%$ (75\% eluent B-1). These eluent compositions initiated rather similar results. The efficiency of the eluent containing $40 \%$ of $\mathrm{CHCl}_{3}(100 \%$ eluent $\mathrm{B}-1)$ can be placed between the aforementioned eluent compositions, it resulted the second lowest area values of all the targeted MAs. Similar results were achieved with the application of $2.5 \% \mathrm{CHCl}_{3}(100 \%$ eluent B-3). Eluent compositions containing $1 \% \mathrm{CHCl}_{3}(100 \%$ eluent $\mathrm{B}-4)$ and $0.5 \% \mathrm{CHCl}_{3}$ (50\% eluent B-4) provided similar and efficient eluent for MA detection, however the highest area values were gained with the eluent composition lacking $\mathrm{CHCl}_{3}(0 \%$ eluent $\mathrm{B})$.

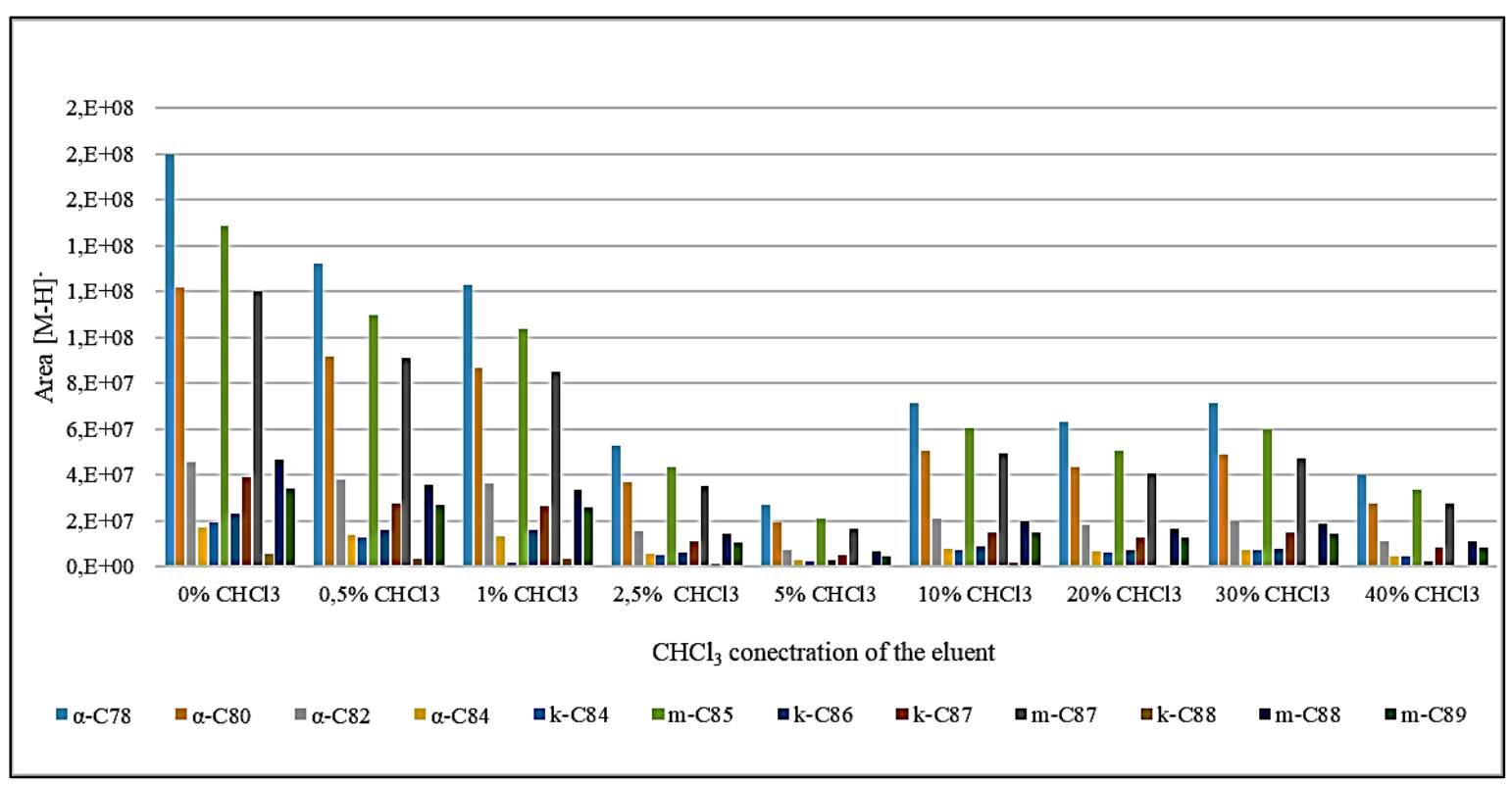

Figure 19: Optimisation of the $\mathrm{CHCl}_{3}$ content of the eluent composition

In a previous study the formation of chloride adducts $[\mathrm{M}+\mathrm{Cl}]^{-}$was described due to the presence of $\mathrm{CHCl}_{3}$ (Song et al., 2009), hence the acquired data was analysed from a second aspect, seeking for the possible chloride adducts. Peaks with the calculated $[\mathrm{M}+\mathrm{Cl}]^{-}$values appeared on the spectrum within -0,495-2,068 ppm identity (Figure 20). 


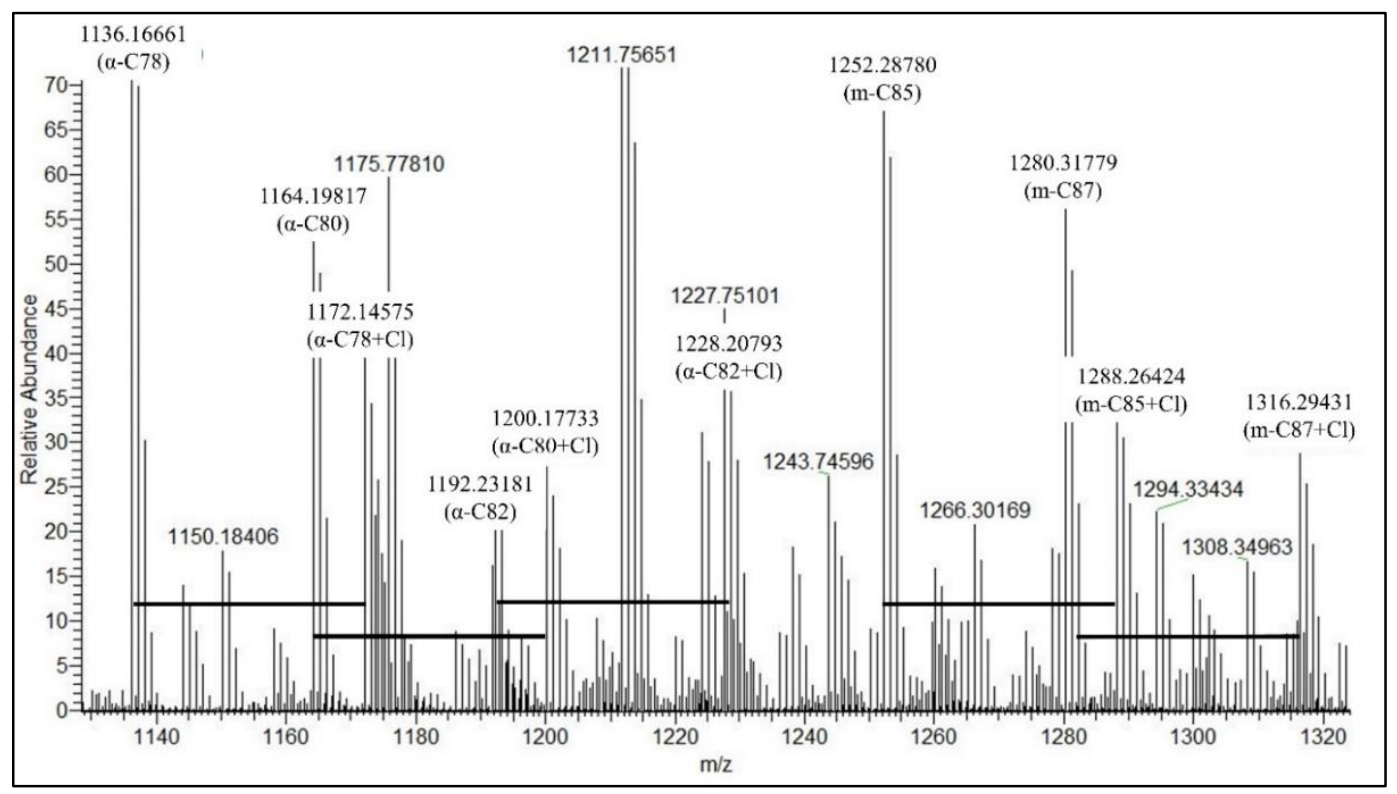

Figure 20: Examples of the observed chloride adducts

The formation of chloride adducts was observed in the case of the application of all eluent compositions. The highest values were detected in the case of the eluents containing $30 \%$ and $40 \% \mathrm{CHCl}_{3}$ (Figure 21). The proportion of chloride adducts followed the decreasing $\mathrm{CHCl}_{3}$ ratio between the range of $40 \%-5 \%$ of $\mathrm{CHCl}_{3}$ concentration. With the further decrease of this highly apolar solvent the presence of the chloride adducts presented an increasing tendency. The eluent containing $1 \% \mathrm{CHCl}_{3}$ provided similar results to those containing $30 \%$ and $40 \%$ of $\mathrm{CHCl}_{3}$. The further decrease of the $\mathrm{CHCl}_{3}$ was followed by decreasing area values of the chloride adduct. Chloride adducts were detected even with application of chloroform-free eluent composition due to the dissolution of samples in $\mathrm{CHCl}_{3}$. However, forming chloride anions purposely in negative-ion ESI-MS analyses, with the application of eluents containing $\mathrm{CHCl}_{3}$ has been reported as a tool for enhancing the detection of compounds, which are lacking highly acidic site - thus would be less efficient to detect in negative ion mode - in our case the formation of these adducts were not beneficial (Zhu \& Cole, 2000). 


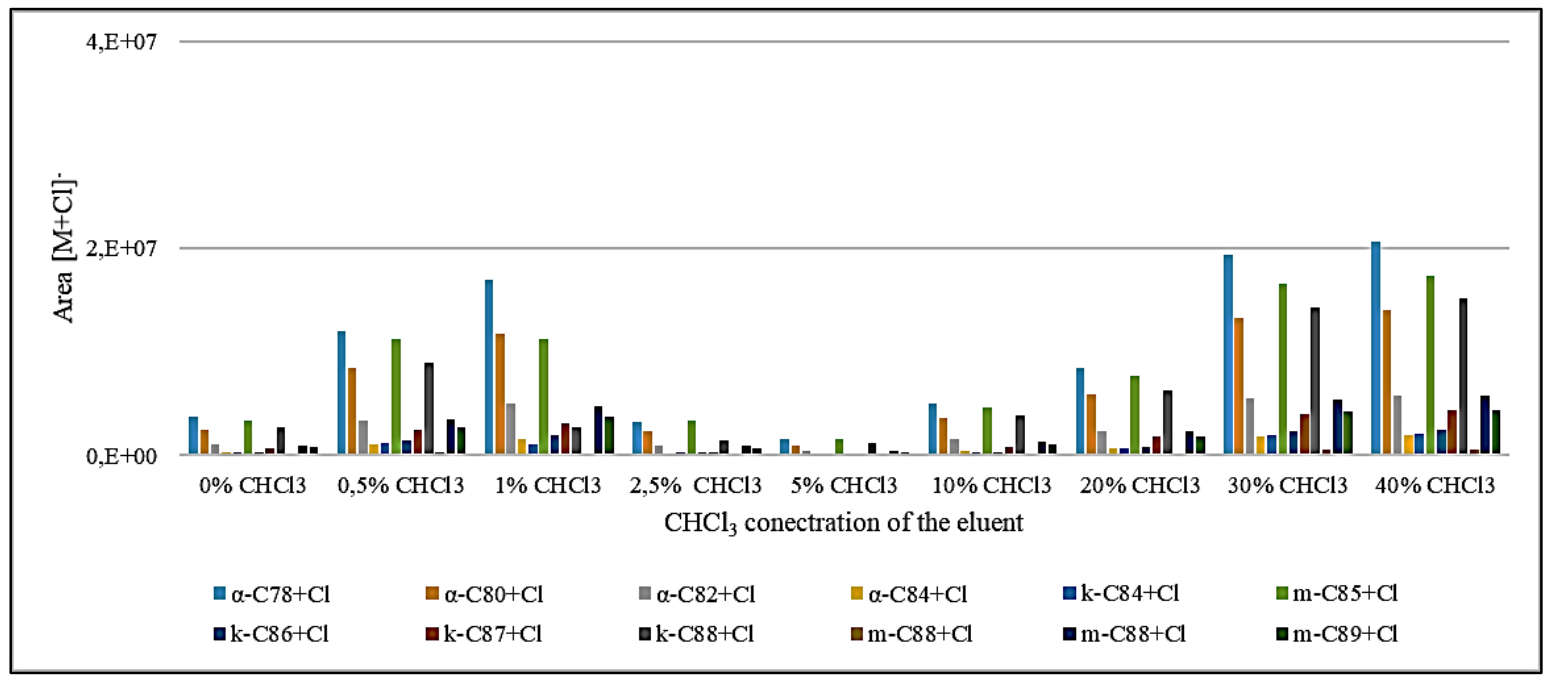

Figure 21: The effect of the $\mathrm{CHCl}_{3}$ concentration on the development of chloride adduct

6.1.2.3 Optimisation of MS parameters along with the application of a chloroform-free solvent

Due to the highly increased area values gained by the application of chloroform-free eluent composition, the application of $\mathrm{MeOH}: \mathrm{ACN}(8: 2)+5 \mathrm{mM} \mathrm{NH}_{4} \mathrm{COOH}$ was chosen for the further investigations in the case of QExactive instrument. With the application of the new solvent mixture the MS parameters were tuned again. Initially, the spray voltage was set. Firstly, its value was increased to $4.5 \mathrm{kV}$ and then to $5 \mathrm{kV}$, each step resulting increased area values (Figure 22 MA06-MA07-MA08). The increase from $4 \mathrm{kV}$ to $5 \mathrm{kV}$ results 1.3 times higher area values. This result is supported by other published methods, as Song and colleagues (2009) has applied similarly high $(4.9 \mathrm{kV})$ capillary voltage. Although the instrumentation of the method published by Szewczyk and colleagues (2013) is not entirely parallel of our used equipment, in their described method $4.5 \mathrm{kV}$ was applied as ionspray voltage. As our optimisation continued, setting the capillary voltage up to $6 \mathrm{kV}$ and $7 \mathrm{kV}$ did not initiate further increase in the area values of the targeted MAs (Figure 22 MA08-MA09MA10). Although the application of $5 \mathrm{kV}$ as capillary voltage was more efficient compared to $4 \mathrm{kV}$, in later measurements the instability of this value was observed, hence the capillary voltage was decreased to $4 \mathrm{kV}$. In the next step the capillary temperature was increased to $400{ }^{\circ} \mathrm{C}$ from $350{ }^{\circ} \mathrm{C}$, which resulted 1.2 times increase in the measured area values. Last, the temperature of auxiliary gas heater was optimised. Increasing this value from $300{ }^{\circ} \mathrm{C}$ to $400{ }^{\circ} \mathrm{C}$ resulted further 1.3 times increase in the area values. Further increase of the auxiliary gas heater temperature up to $450{ }^{\circ} \mathrm{C}$ resulted a minimal decrease in the area values. The temperatures providing the best results were close to maximum values, which can be applied on the equipment. The overall intensity increase, gained by the introduced optimisation 
steps, was up to $230 \%$. The application of particularly high temperature was also described in the ESI-MS/MS method developed by Szewczyk and colleagues (2013), within the ionspray temperature was set to $650{ }^{\circ} \mathrm{C}$, however the method described by Bhamidi and colleagues (2011) involved the drying gas and vaporiser temperature set to $300{ }^{\circ} \mathrm{C}$ and 200 ${ }^{\circ} \mathrm{C}$, respectively on a TOF mass spectrometer supplemented with an APCI/ESI multimode source.

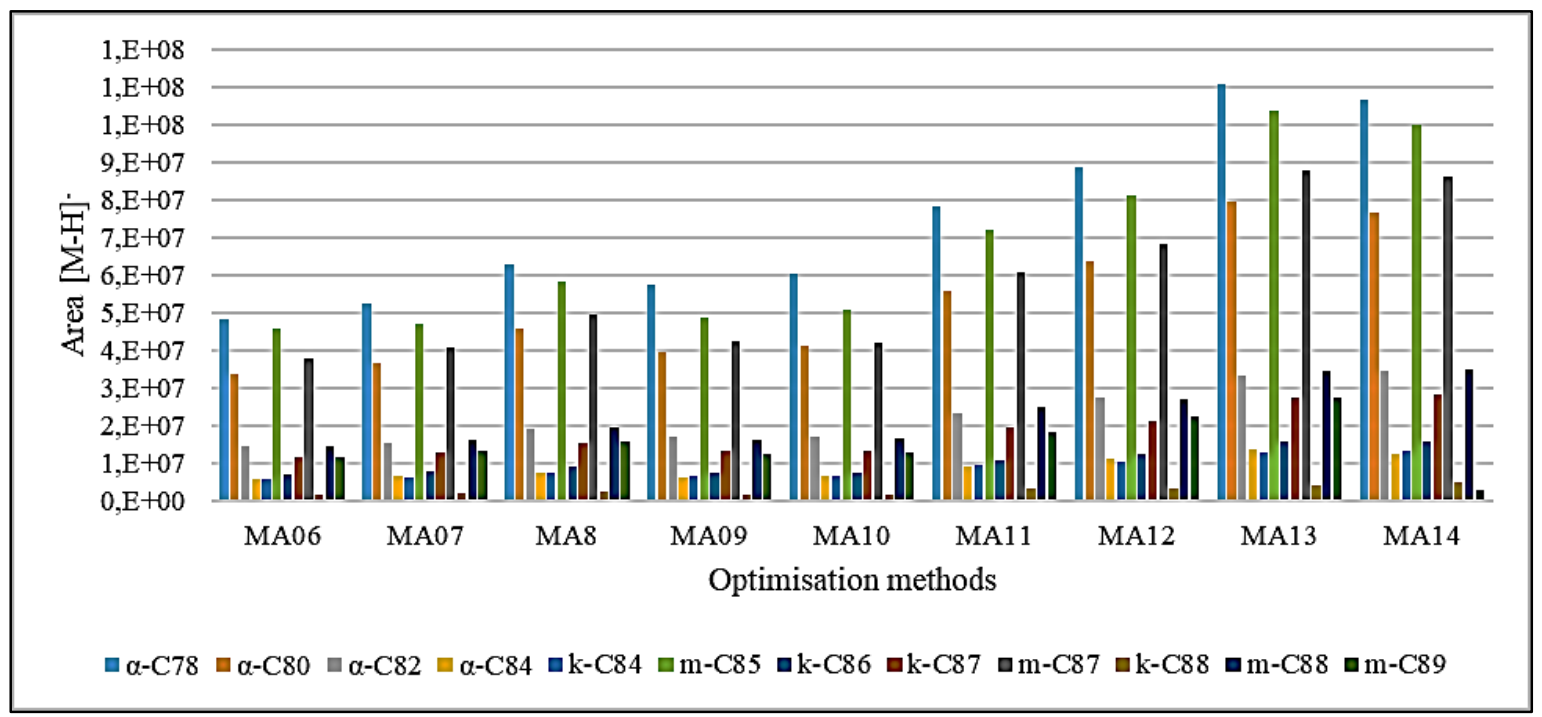

Figure 22: Optimisation of MS setting with the application of MeCN:MeOH (8:2) + 5mM ammonium formate eluent

\subsubsection{Optimisation of the sample pre-treatment protocol}

Beside the optimisation of the detection method of the selected lipids their extraction protocol was also fine-tuned. Initially three different $\mathrm{KOH}$ concentration were compared with the involvement of 2 representatives of each MA types. In the original published method 30\% (m/V) KOH, dissolved in $\mathrm{MeOH}$, was applied for saponification, followed by extraction with toluene (Hershkovitz et al., 2008). All the targeted MAs were providing detectable peaks (Figure 23). The application of $20 \% \mathrm{KOH}$ did not affect the amount of the extracted MAs. Further decrease of the $\mathrm{KOH}$ ratio in the solution down to $10 \%$ negatively affected the efficiency of the saponification regarding MAs. During this sample preparation round the effect of two extraction solvents, toluene and hexane was also compared. The application of hexane isomer mixture for extraction, after saponification with $30 \% \mathrm{KOH}$, resulted 1.3 times higher outcome regarding the involved $\alpha$-MA specimens and a slighter, approximately $20 \%$ increase in the case of methoxy-MA, while negatively affected the efficiency of the extraction of keto-MAs. The application of hexane isomer mixture beside 
$10 \% \mathrm{KOH}$ concentration provided similar result to those gained with the application of toluene.

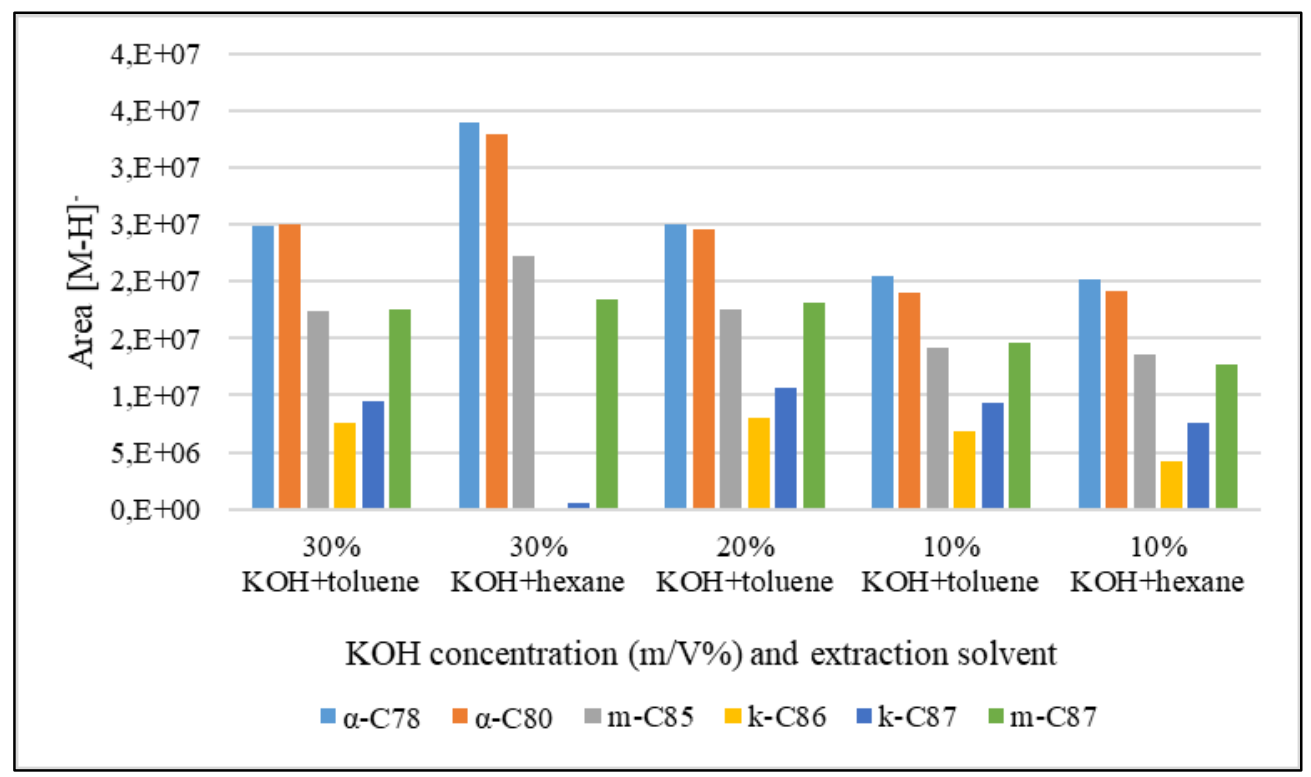

Figure 23: Comparison of different $\mathrm{KOH}$ concentrations and the appliaction of toluene and hexane as extraction solvents

The previously introduced results suggested that the application of hexane has a good effect on the extraction of $\alpha$ - and methoxy-MAs, but for the extraction of keto-MAs the application of toluene is necessary, hence in this comparison the originally used extraction 3 times with toluene (T) was supplemented with one additional hexane isomer mixture extraction $(\mathrm{H})$, followed by the pooling of the extracted organic layers (Figure 24). This extraction scheme was tested in an other composition within the extraction with toluene was supplemented with one additional petroleum ether $(\mathrm{PE})\left(60-80{ }^{\circ} \mathrm{C}\right)$ extraction. Furthermore, the application of a 3 times petroleum ether $(\mathrm{PE})\left(60-80^{\circ} \mathrm{C}\right)$; and the application of one time methyl tert-butyl ether (MTBE), one time hexane, and one time PE extraction protocolts were tested. Regarding the $\alpha$ - and methoxy-MAs the application of the toluene-hexane extraction provided the best results. The extraction carried out with PE resulted the second best efficiency of $\alpha$-MA extraction. The highest keto-MA content was measured from samples extracted with only PE, however the amount of methoxy-MAs decreased compared to the previously described results. The extraction carried out with toluene supplemented with PE provided the second best results regarding the methoxy-MAs, although the efficiency of the $\alpha$ - and keto-MA extraction was behind the efficiency of the previous two extraction solvents. The lowest extraction outcome regarding all MAs was achieved with the application of the solvent mixture consisting MTBE, hexane and PE. For further application $20 \% \mathrm{KOH}$ 
solution and toluene supplemented with hexane isomer mixture has been chosen for sample pre-treatment.

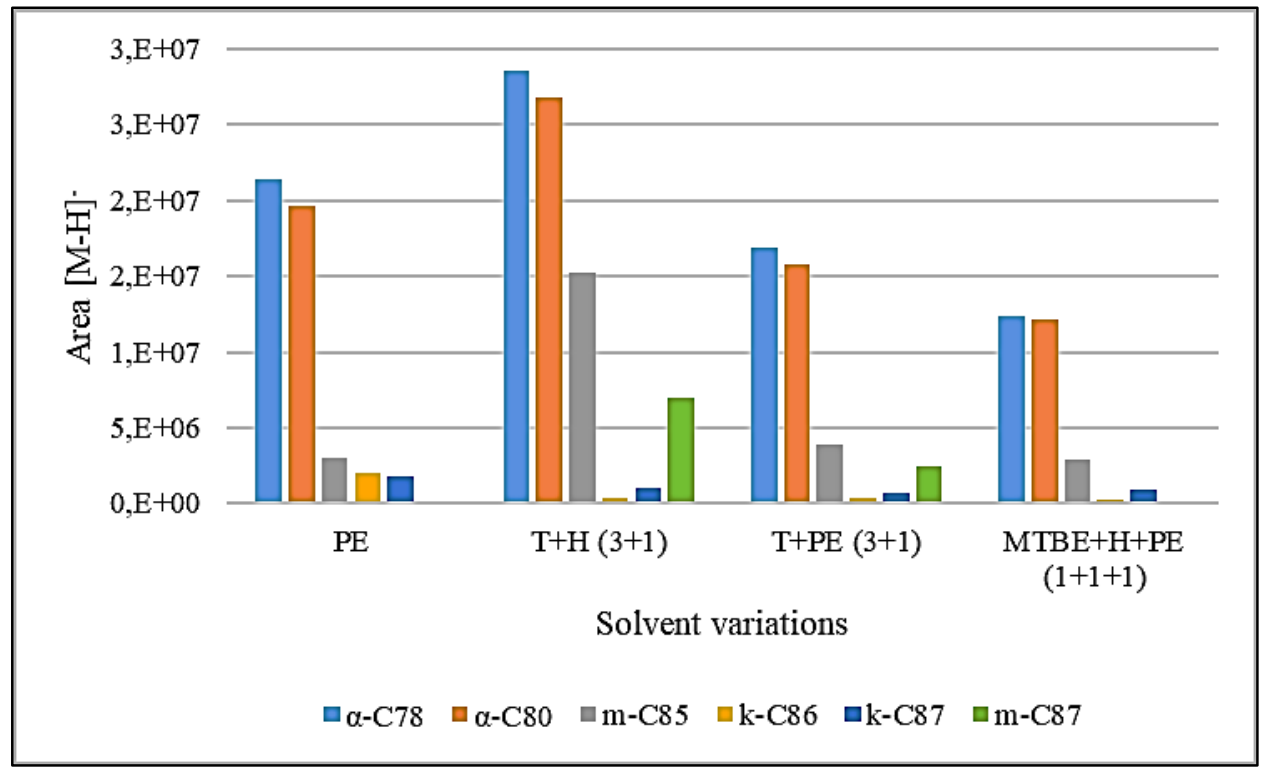

Figure 24: Comparison of the effect of 4 extraction solvent compositions

Very diverse sample pre-treatment protocols are described in studies covering MA detection methods from sputum and bacterial samples, whose diversity originated from the number of detection techniques applied for the MA measurements. However, in these methods there are some commonly used steps, such as the saponification and the acidification before the extraction into the non-polar organic solvent. In the method applied by Yoshino and colleagues (2018) the pre-treatment started with saponification of the bacterial cell material with the application of $5 \mathrm{~N} \mathrm{NaOH}$. Samples were heated for $20 \mathrm{~min}$ at $121{ }^{\circ} \mathrm{C}$. The cooled samples were acidified prior to the extraction with n-hexane. The collected organic phase was first washed with water. After discarding the water, $\mathrm{CHCl}_{3}$ was added to samples. It was followed by double overnight precipitation of MAs with the addition of $\mathrm{MeOH}$. From the purified crude MA fraction MA methyl esters (MA-ME) were prepared with the application of $10 \%$ tri-methylsilyldiazomethane in n-hexane. MA-MEs were checked by TLC. After recovering the purified MA-ME fraction with the application of $\mathrm{CHCl}_{3}: \mathrm{MeOH}(9: 1)$ the samples were autoclaved with the addition of toluene, $\mathrm{MeOH}$ and $\mathrm{NaOH}$. Samples were acidified and further extracted with n-hexane.

Bhamidi and colleagues (2011) described a complex experimental study regarding the cell wall core structure of $M$. tuberculosis and M. leprae. As many $\mathrm{CW}$ components were involved in their investigation, the purification of MAs was carried out with a complex 
protocol. Initially the mAGP matrix was extracted mechanically in PBS buffer. The gained pellet was suspended overnight in $2 \%$ SDS dissolved in water. After the removal of the supernatant the pellet was heated at $100{ }^{\circ} \mathrm{C}$ in SDS solution for an hour. The resulted pellet was suspended in $80 \%$ acetone. After the removal of SDS samples were washed in water and treated with $\mathrm{CHCl}_{3}: \mathrm{MeOH}(2: 1)$ to remove the free MAs. The extracted mAGP was treated with TFA for $2 \mathrm{~h}$ at $121^{\circ} \mathrm{C}$ and extracted with $\mathrm{CHCl}_{3}$. MAs were de-esterified from the AGP matrix by alkaline hydrolysis, followed by acidification. The acidified samples were extracted with diethyl ether.

In contrast with the above described protocols in many studies less complex methods were used for pre-treament, which are more similar to the one used in our study. Teramoto and colleagues (2015) initiated their sample treatment with saponification in $10 \% \mathrm{KOH}$ dissolved in $\mathrm{MeOH}$, for 2 hours, while the samples were heated at $90^{\circ} \mathrm{C}$. MAs were extracted with hexane, prior to MA-ME development with diazomethane. The initiate alkaline hydrolysis in the study of Song and colleagues (2009) was carried out with the application of $25 \% \mathrm{KOH}$ in $\mathrm{MeOH}: \mathrm{H}_{2} \mathrm{O}(1: 1)$ for an hour at $90{ }^{\circ} \mathrm{C}$, followed by the addition of $\mathrm{CHCl}_{3}$ and $\mathrm{HCl}$. The removed organic layer was used for further MA analysis. Similar approach was applied by Szewczyk and colleagues (2013), however, they pre-washed the cells in $\mathrm{MeOH}$, the $\mathrm{KOH}$ was dissolved in $\mathrm{MeOH}$, and the extraction with $\mathrm{CHCl}_{3}$ was carried out in a separate step. Pre-treatment before saponification was applied by Sui and colleagues (2012), as well. For the inactivation of the pathogens and the removal of free-lipids samples were shaken overnight in $\mathrm{CHCl}_{3}: \mathrm{MeOH}(2: 1)$ at $4{ }^{\circ} \mathrm{C}$. After separating the layer with the addition of $\mathrm{H}_{2} \mathrm{O}$ organic solvents were removed, and the pre-treatment was repeated, while pooling the collected organic layers. The appearing intermediate layers were collected, dried and treated with $20 \%$ tetrabutylammonium hydroxide. Samples were heated at $105{ }^{\circ} \mathrm{C}$ for 2 hours. The cooled samples were acidified and extracted with hexane. Relatively high, $40 \%$ $\mathrm{KOH}$ concentration was applied by Laval and colleagues (2001). Bacterial cells were heated for 3 hours at $100{ }^{\circ} \mathrm{C}$ in the aqueous $\mathrm{KOH}$ solution and methoxy ethanol. After acidification MAs were extracted with diethyl ether. MA-ME were prepared with diazomethane solution.

\subsubsection{Mycolic acid profile establishment of MTBC and NTM strains}

After optimising the sample pre-treatment and detection method, development of mycobacterial MA profile library has been started. As a "test library" the MA profiles of MTBC-1/2015; MTBC-254/2000; MTBC-3910/2014; MTBC-242/2000; and MTBC1/8508/2014 (Figure 25), Mycobacterium gordonae 389/2018, Mycobacterium 
intracellulare 7802/2017, Mycobacterium abscessus ssp. abscessus 180/2018, M. kansasii 1959/2018 and Mycobacterium chelonae 16/2018 have been established.

The calculated distribution of the main MA types is based on the MA specimens listed in Table 4 (Materials and Methods). The $\alpha$-C78 was found to be the most abundant MA in all the included MTBC strains, however in the case of MTBC-1/2015, it was equally represented with the m-C85 MA. The second most represented MA was the $\alpha-C 80$ in the case of MTBC-242/2000, MTBC-254/2000 and MTBC-3910/2014 and m-C85 in MTBC1/8508/2014. An other methoxy-MA, the m-C87 was also highly represented in most of the cases, with the exception of MTBC-1/8508/2014. $\alpha-C 82, \mathrm{~m}-\mathrm{C} 88, \mathrm{k}-\mathrm{C} 87$ and m-C89 were also represented in higher, than $5 \%$ in 4 out of the 5 analysed strains, although the latter one was hardly detected in MTBC-1/8508/2014. Most of the keto-MAs, except k-C87, distributed in a low level, however k-C84 was found to be present in a high ratio in one strain, namely in MTBC-1/8508/2014. The clinical isolates MTBC-254/2000, MTBC3910/2014 and MTBC-242/2000 provided rather similar MA profile, while the lipid composition of MTBC-1/2015 and especially MTBC-1/8508/2014 represented an exception in many aspects.

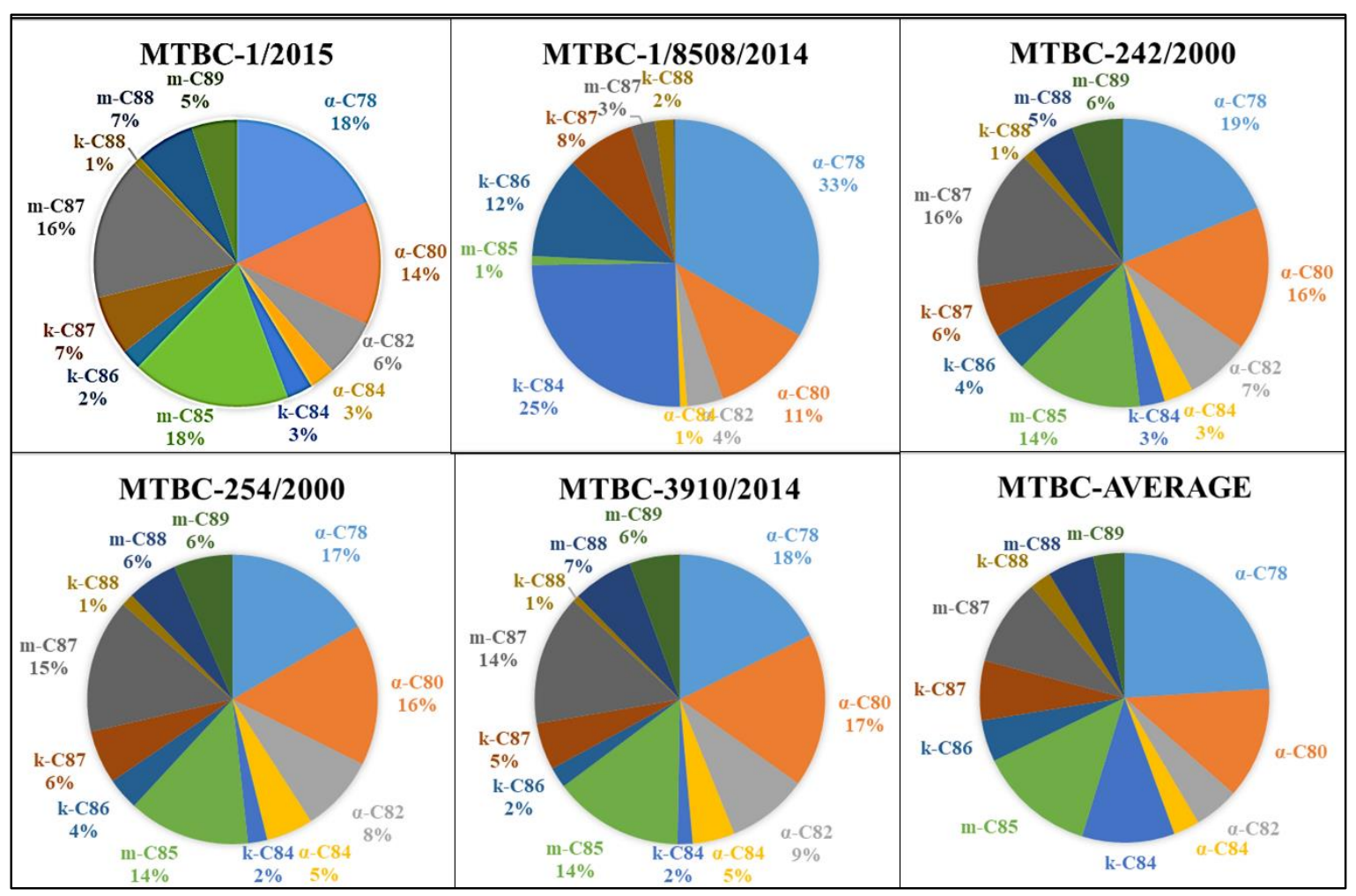

Figure 25: MA profiles of 5 MTBC strains, isolated from patients 
Similar results were described by Borowska-Strugińska and colleagues (2014) and Bhamidi and colleagues (2011). Both team described $\alpha$-C78 MA as the most represented one, however the former team find the $\alpha-\mathrm{C} 80, \mathrm{~m}-\mathrm{C} 87, \mathrm{~m}-\mathrm{C} 85$ highly represented, respectively, while in the latter study the abundance of $\alpha-\mathrm{C} 78$ was followed by m-C85, m-C87, $\alpha-\mathrm{C} 80$, respectively, although both profiles were acquired from the M. tuberculosis $\mathrm{H} 37 \mathrm{Rv}$ strain. The profile regarding the $\alpha-\mathrm{C} 82, \mathrm{k}-\mathrm{C} 87, \mathrm{~m}-\mathrm{C} 89$, m-C88, k-C86, $\alpha-\mathrm{C} 84$ and k-C88 MAs were similar. In our calculated MTBC-average profile $\alpha-\mathrm{C} 82$ and k-C 86 were equally represented, followed by k-C84, k-C87, m-C89/m-C88, $\alpha-C 84$ and k-88, respectively.

Considering the summarised values of individual MA-s based in their type the $\alpha$-MAs were represented in the highest ration in 4 strains, namely in MTBC-254/2000; MTBC3910/2014; MTBC-242/2000; and MTBC-1/8508/2014 (Figure 26), ranging between 40\%$50 \%$. The highest summarised area values in the MTBC-1/2015 strain belonged to methoxyMA specimens, which were slightly less represented in the other 4 strains, adding up to approximately $40 \%$ of the overall area values. The least represented MA type was the ketoMA in every cases. The high representation of $\alpha$-MAs in considered to be typical in the case of slow growing mycobacteria (Laval et al., 2001), although it does not have any diagnostic value in itself, as for example in the case of M. bovis BCG strain the summarised keto-MAs were find to be the most represented (Yoshino et al., 2019). In the experiment of Bhamidi and colleagues (2011) the relative ratios of the MA types, derived from M. tuberculosis H37Rv, were almost identical with the above described results, including $9 \alpha-, 9$ methoxy and 7 keto-MA specimens. Summarising the published abundance in per cent form published by Borowska-Strugińska and colleagues (2014), in their study $\alpha$-MAs were present in $45 \%$, methoxy-MAs in $37 \%$, keto-MAs in $18 \%$. Regarding the reference strain used for diagnosis of TB infection in ancient human bone material Hershkovitz and colleagues (2008) published the following per cent distribution: $\alpha$-MAs were represented in $48 \%$, methoxyMAs in 37\% and keto-MAs in 14\% (Minnikin et al., 2012). 


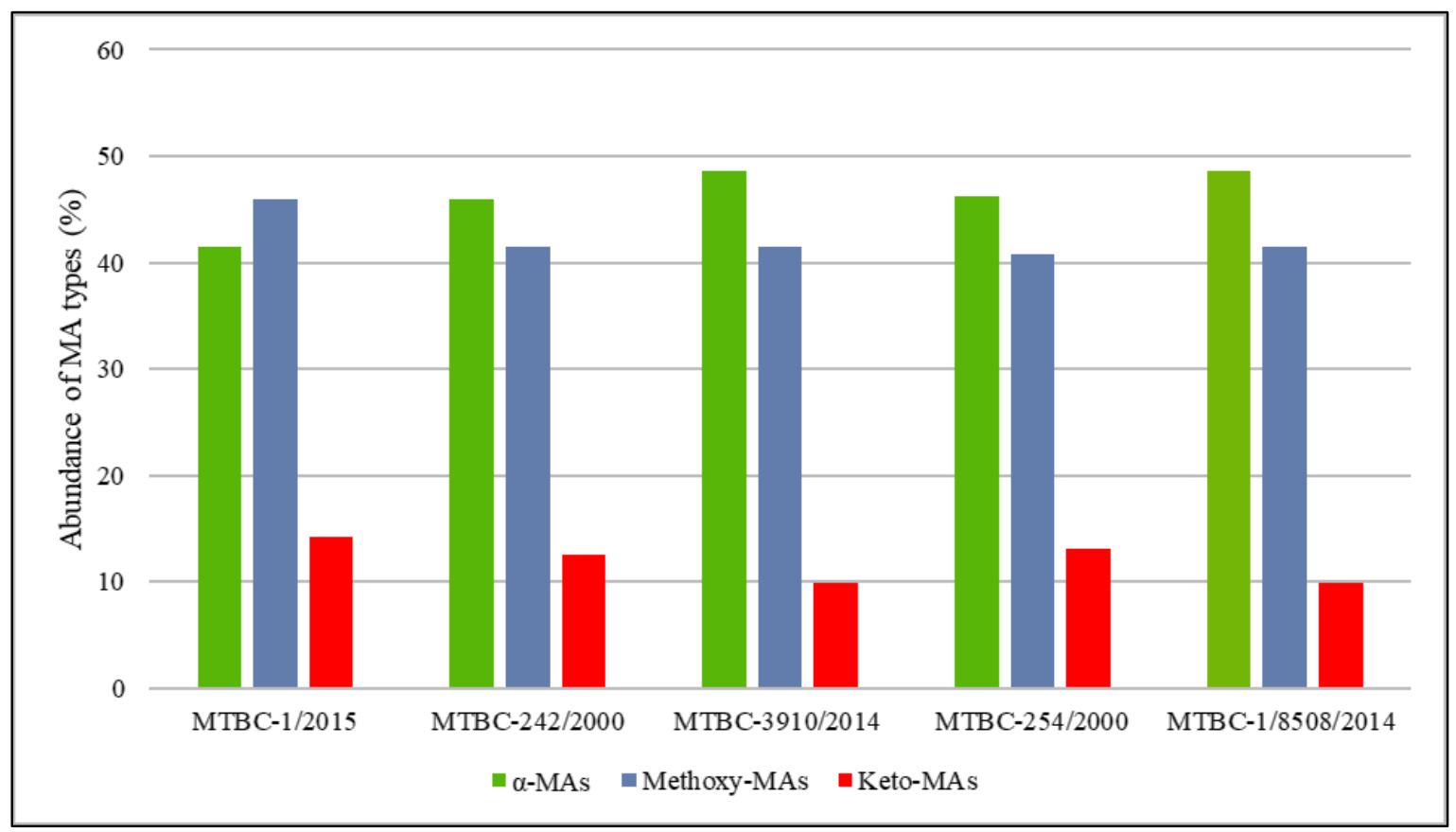

Figure 26: The distribution of the 3 main MA types in the 5 MTBC strains, isolated from patients

The MA profiles of M. kansasii 1959/2018, Mycobacterium gordonae 389/2018, Mycobacterium intracellulare 7802/2017, Mycobacterium abscessus ssp. abscessus 180/2018 and Mycobacterium chelonae 16/2018 draw a more diverse picture (Figure 27). The most abundant MA specimen was the $\alpha$-C78 MA similarly to the analysed MTBC strains, however, its distribution was much higher among the included NTM species. The second most abundant MA was the $\alpha-C 80$, with the exception of $M$. intracellulare $7802 / 2017$, in which case the representation of $\alpha$-C80 was the most prominent compared to $\alpha-\mathrm{C} 78$. The $\alpha-\mathrm{C} 82$ was detected in all the analysed cases. The abundance of the individual methoxy- and keto-mycolates is very various. The m-C85 MA was represented in 10\% or above in the case of M. kansasii 1959/2018, M. gordonae 389/2018 and M. abscessus ssp. abscessus 180/2018, and being present with 5\% abundance in M. intracellulare 7802/2017. All the other methoxy-MA specimens were represented in less than 5\%, with the exception of m-C87 presenting 9\% abundance in M. abscessus ssp. abscessus 180/2018 and 6\% abundance in M. kansasii 1959/2018. Among the included keto-MAs k-C84 was represented in 6\% and 5\% in the case of M. kansasii 1959/2018 and M. gordonae 389/2018, respectively, furthermore, k-C87 had 8\% abundance in M. kansasii 1959/2018. All the other not described, monitored MAs represented less than 5\% abundance in the analysed NTM strains. 


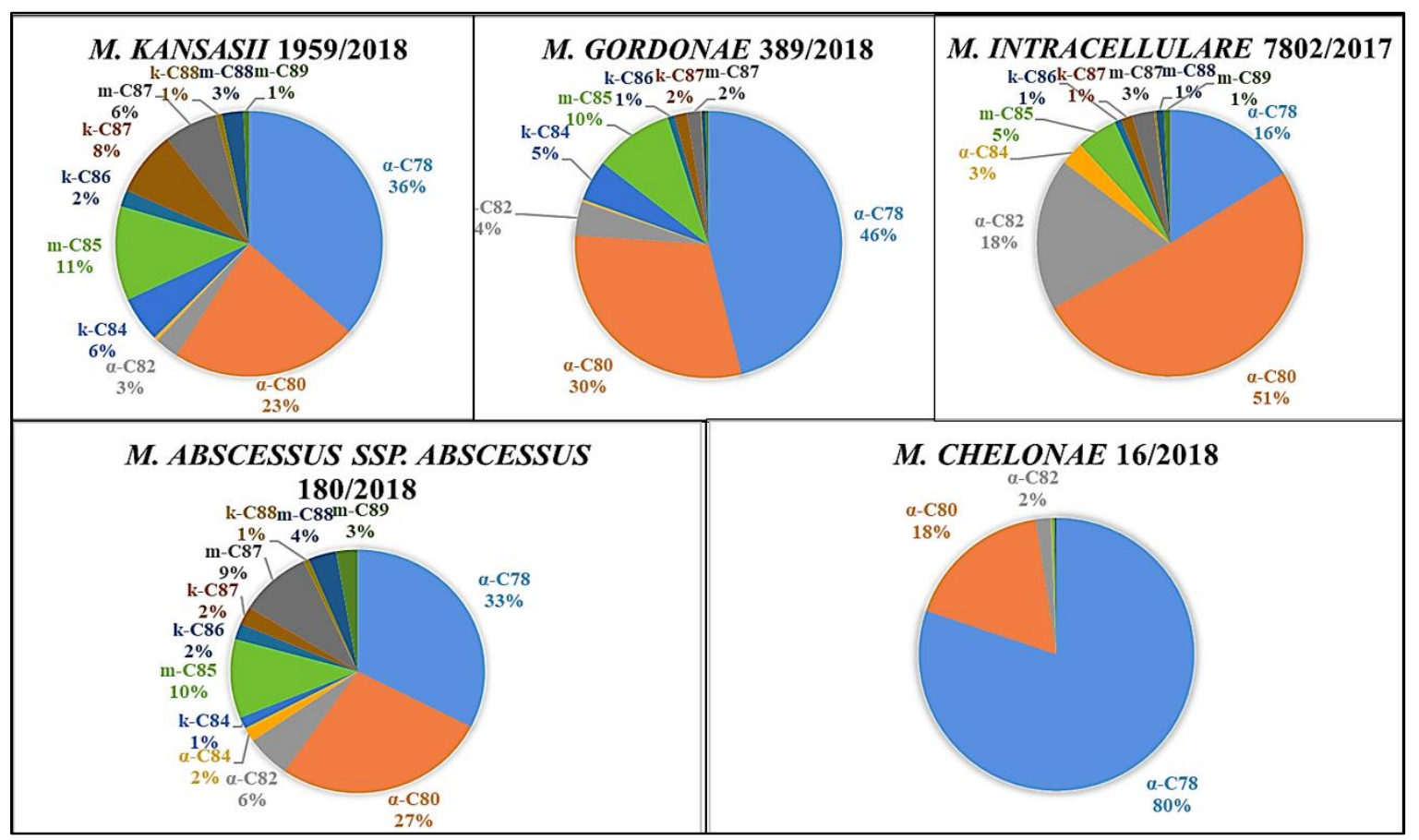

Figure 27: MA profiles of 5 NTM strains, isolated from patients

In the study published by Szewczyk and colleagues (2013) $\alpha$-C78, $\alpha-\mathrm{C} 80, \alpha-\mathrm{C} 82, \alpha-\mathrm{C} 84, \mathrm{~m}-$ $\mathrm{C} 85, \mathrm{k}-\mathrm{C} 86, \mathrm{k}-\mathrm{C} 87$ and $\mathrm{m}-\mathrm{C} 87$ were monitored and the following NTM species were included: M. kansasii, M. intracellulare, M. abscessus and M. avium. According to their findings the most abundant MA specimen was the $\alpha-\mathrm{C} 78$ in every cases. In M. kansasii mC85 was also highly represented, with $39 \%$ abundance. The abundance of $\alpha-C 80, \alpha-C 82$ and $\mathrm{k}-\mathrm{C} 87$ was calculated to be $1.11 \%, 1.13 \%, 1.81 \%$ respectively, the other monitored MA specimens were represented in less than $1 \%$ each. During the analysis of $M$. intracellulare $\alpha-\mathrm{C} 78$ represented the $98 \%$ of overall abundance, meanwhile the abundance regarding the rest of the MAs were below 1\%, moreover k-C86 was not detected at all. In the case of $M$. abscessus $\alpha-\mathrm{C} 78$ was registered with $98 \%$ abundance, all the other monitored MAs were represented in less than $1 \%$ of the overall distribution, each. Based on the published mass spectra profile of Shui and colleagues (2011) in M. kansasii the most abundant peak belonged to $\alpha-\mathrm{C} 80$, followed by k-C85 (this MA not included in our analysis, but it was detected during the analysis). Peaks belonging $\alpha-C 78$ and k-C87 were highly abundant, appearing with nearly the same intensity and $\alpha-82$ was also detected. On the mass spectrum of $M$. gordonae among those MAs, which are included in our analysis the presence of $\alpha$-C78 and $\alpha$-C80 (respectively to their abundance) can be observed. In the case of M. abscessus and $M$. chelonae they have detected the total lack of oxygenated MA species, moreover the abundant $\alpha$-MAs had shorter alkyl-chain than the ones included in our study. Song and colleagues 
(2009) analysed the MA profile of several mycobacteria based on the length of their $\alpha$-chain. Their study involved M. intracellulare and according to their published mass spectrum $\alpha$ $\mathrm{C} 78, \alpha-\mathrm{C} 80$ and $\alpha-\mathrm{C} 82$ were the most abundant MA specimens, beside m-C68. In the case of $M$. gordonae a broader variety of MAs were detected, namely the $\mathrm{m} / \mathrm{k}-\mathrm{C} 81, \mathrm{~m} / \mathrm{k}-\mathrm{C} 83$, $\mathrm{m} / \mathrm{k}-\mathrm{C} 85, \alpha-80, \alpha-78$ being the most abundant, beside smaller MAs, which were not included in our study, such as $\alpha-\mathrm{C} 76, \alpha-\mathrm{C} 74, \mathrm{~m} / \mathrm{k}-\mathrm{C} 76, \mathrm{~m}-\mathrm{C} 81, \mathrm{~m} / \mathrm{k}-\mathrm{C} 82$.

Considering the summarised values of individual MA-s based in their type in the analysed NTM species a distinct distribution can be observed, compared to MTBC. Although the highest abundance belongs to the $\alpha$-MAs in these cases, as well, the oxygenated MA-s are less or hardly even represented (Figure 28). In every cases $\alpha$-MAs were more than $60 \%$ abundant. In M. kansasii 1959/2018 mycolates belonging to $\alpha$-MAs gave a bit more, than the $60 \%$ of all MA area values, followed by methoxy- and keto-MAs, which represented the $21 \%$ and $17 \%$, respectively. In M. chelonae keto-MAs were absent, and the overall methoxyMAs were represented in less than 1\%. The abundance of $\alpha$-MAs of M. gordonae 389/2018 was $80 \%$, meanwhile methoxy- and keto-MAs were distributed in $12 \%$ and $7 \%$, respectively. The extracted MAs of $M$. intracellulare $7802 / 2017$ consisted $\alpha$-MAs in $88 \%$, methoxy-MAs in $9 \%$ and keto-MAs in 2\%. The MA profile of M. abscessus ssp. abscessus 180/2018 based on $65 \% \alpha$-MAs, $28 \%$ methoxy-MAs and $7 \%$ keto-MAs.

In contrast, the detailed review about mycobacterial lipids published by Minnikin and Brennan (2020) suggests that in the members of M. avium complex (e.g. M. intracellulare) methoxy-MAs are replaced by wax-ester MAs, moreover MAs of M. chelonae and $M$. abscessus contain only comparable amounts of $\alpha$ - and shorter alkyl-chain $\alpha$ '-MAs, which were not included in our investigations. The aforementioned differences in our results implies the need of further investigation of these NTM strains and the re-consideration of their profile given by our results. 


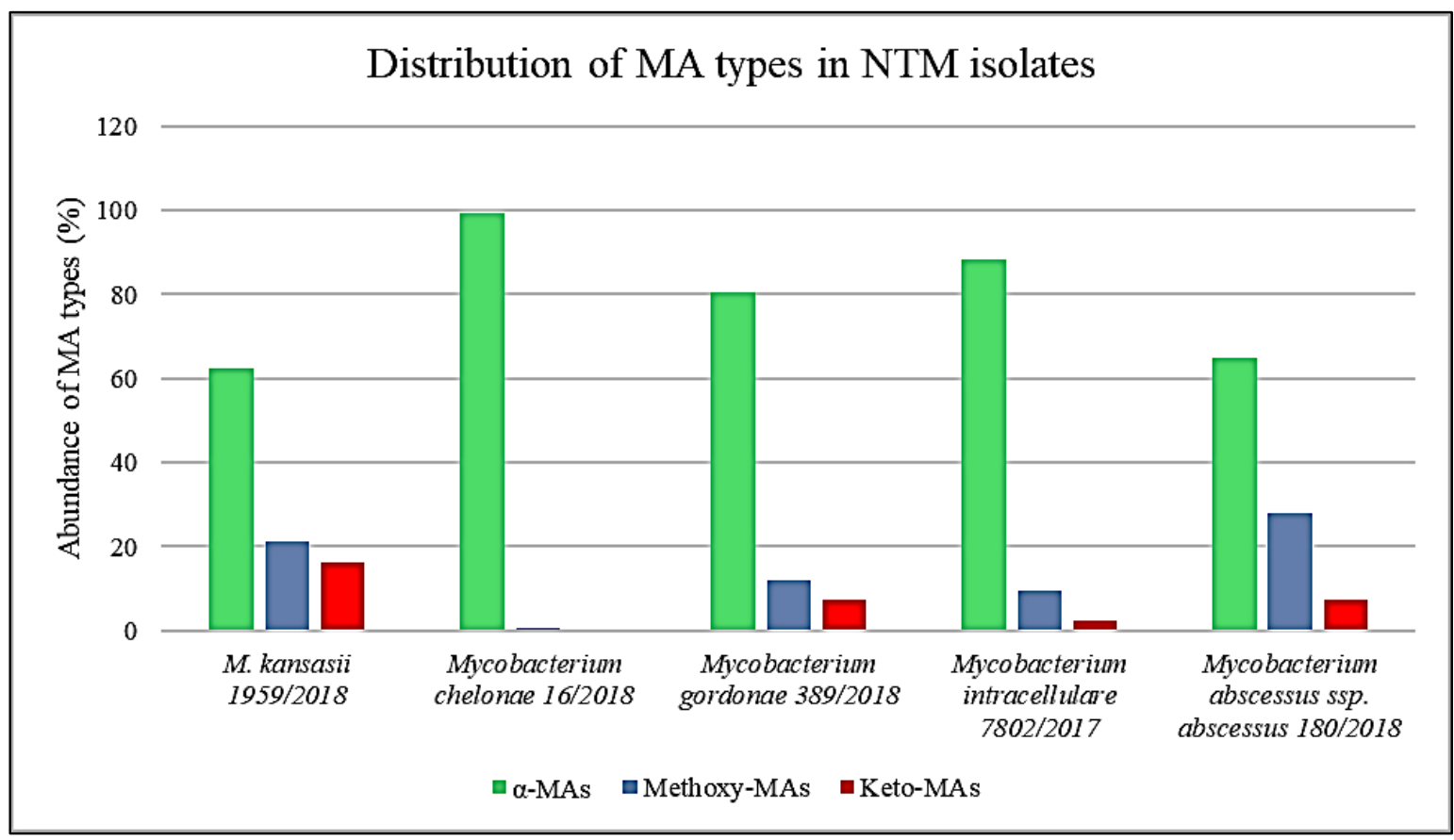

Figure 28: The distribution of the 3 main MA types in the 5 NTM strains, isolated from patients

6.1.2.6 Optimisation of a new eluent composition for combined detection of MAs and MCs As the above discussed examples present, the comparison of lipid profiles belonging to NTM species has limits. It can be implicated from the different sample set (e.g. clinical isolates or reference strains), the different sample pre-treatment protocols and depends on the used instrumentation, since the numerous approaches are available. In our results the oxygenated MA-s were more represented in the NTM species, as the aforementioned literature would imply. For the support of our results, a new method was developed, capable of the separation and detection of mycocerosates and MAs. Firstly the following eluent composition was tested without and with 3 commonly used additives $(5 \mathrm{mM}$ ammonium formate; $0.1 \%$ acetic acid; $0.1 \%$ formic acid): $\mathrm{MeOH}: \mathrm{ACN}: \mathrm{CHCl}_{3}: \mathrm{IPA}$ (6:1:0.5:2.5). With the application of the standard eluent without any additives all the monitored MAs provided recognisable peaks (Figure 29.1). The same eluents composition, supplemented with 5mM ammonium formate provided similar results, however a slight, approximately $30 \%$, increase was noted in the area values (Figure 29.2). With the application of $0.1 \%$ acetic acid with the exception of $\alpha$ C78 MA the area value of all the target molecules increased, especially in the case of the oxygenated MAs (Figure 29.3). The integrated area of $\alpha-C 80, \mathrm{~m}-\mathrm{C} 85$, k-C86, k-C87, m-C87 were 1.3; 1.6; 2 and 3 times larger, respectively. The same eluent composition supplemented with $0.1 \%$ formic acid resulted a decreased ionisation of MAs (Figure 29.4). An other, more non-polar eluent composition was also tested with the two additives, which presented positive effect in the previous comparison. The eluent consisted IPA:heptane:ACN (4:1:5), 
and was tested first with the addition of $0.1 \%$ acetic acid and $5 \mathrm{mM}$ ammonium formate. In the former case a great increase of the detected peaks was observed. In the case of $\alpha$-C78, $\mathrm{m}-\mathrm{C} 85$, $\mathrm{k}-\mathrm{C} 86$ and $\mathrm{k}-\mathrm{C} 87$ an increase up to $250 \%$ was achieved, while the are values of $\alpha$ $\mathrm{C} 80$ and $\mathrm{m}-\mathrm{C} 87$ presented 5 times increase (Figure 29.5). The addition of $5 \mathrm{mM}$ ammonium formate to this eluent composition resulted 50\% decrease in the integrated are values (Figure 29.6).

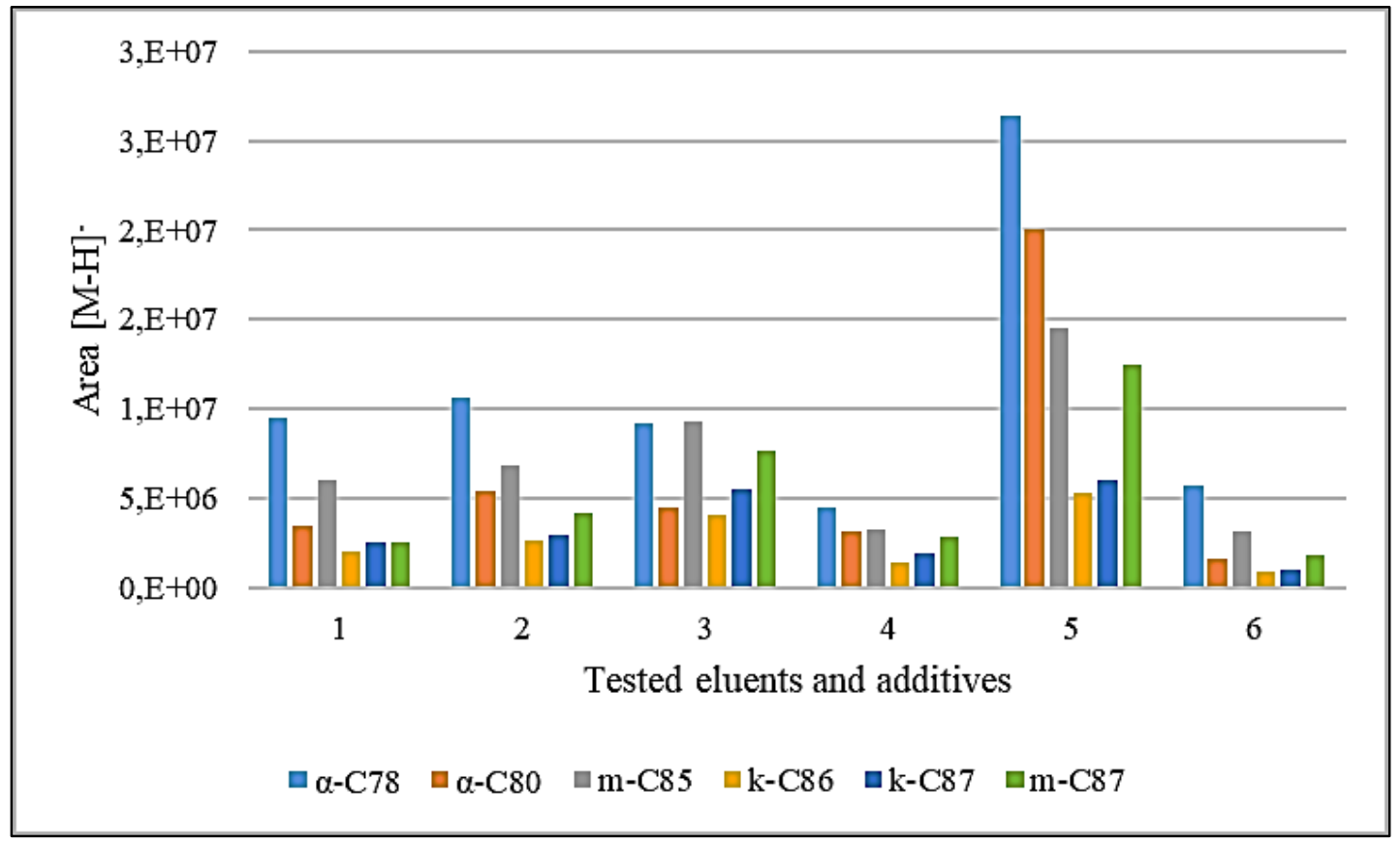

Figure 29: Optimisation of a less polar eluent composition

\subsubsection{Mycocerosic acid separation and detection by Q-Exactive Plus Orbitrap MS}

Firstly, the possibility of MC-MA separation was tested on a Gemini - NX C18 column with the previously selected eluent composition (eluent A was $\mathrm{MeCN}$, containing $0.1 \% \mathrm{AcOH}$ $(\mathrm{AcOH})$, eluent B consisted of IPA:heptane (8:2), supplemented with $0.1 \% \mathrm{AcOH})$. The separation was carried out with gradient elution starting at $10 \%$ B eluent, and was increased according to the following steps: $0 \min 10 \%$ B, $5 \min 15 \%$ B, $15 \min 70 \%$ B, $16 \min 90 \%$ B, $18 \min 90 \%$ B, $18.5 \min 20 \%$ B, $19.5 \min 20 \%$ B, $20 \min 90 \%$ B, $23 \min 90 \%$ B, $24 \min$ $10 \% \mathrm{~B}$ and $28 \mathrm{~min} 10 \% \mathrm{~B}$. For the analysis lipids were extracted from M. tuberculosis $1 / 2015$.

On the combined extracted ion chromatograms (EICs) both lipid biomarkers were observed (Figure 30). Due to the much shorted alkyl-chain of mycocerosic acids, their retention time was shorter compared to the mycolic acids. The targeted mycocerosic acids (Table 7) eluted between 6 and $10 \mathrm{~min}$, while MAs were detected between 15-16 min. During the 
chromatographic run the first eluting component was the C27 mycocerosic acid (Rt: 6.26), the second was the C29 (Rt: 7.81), followed by C30 (Rt: 8.13), C32 (Rt: 9.37) and C33 (Rt: 9.52), respectively. The recorded mycobacterial mycocerosate HPLC profiles, correspond well with those recorded previously by NI-CI GC-MS of PFB esters (Lee et al., 2012; Redman et al., 2009; Donoghue et al., 2017). In comparison, the C29 and C30 MCs cochromatographs with the application of the GC-MS method. In the HPLC measurement, the additional carbon in the $\mathrm{C} 30 \mathrm{MC}$ ensures that it is retained longer by the reverse phase column media, subtle structural differences being less influential in the liquid phase. A similar relationship can be observed for the C32 and C33 MCs.

Despite of this highly non-polar solvent composition the elution of MAs was not complete, especially in the case of MAs with longer alkyl-chain length (e.g. k-C86, k-C87).

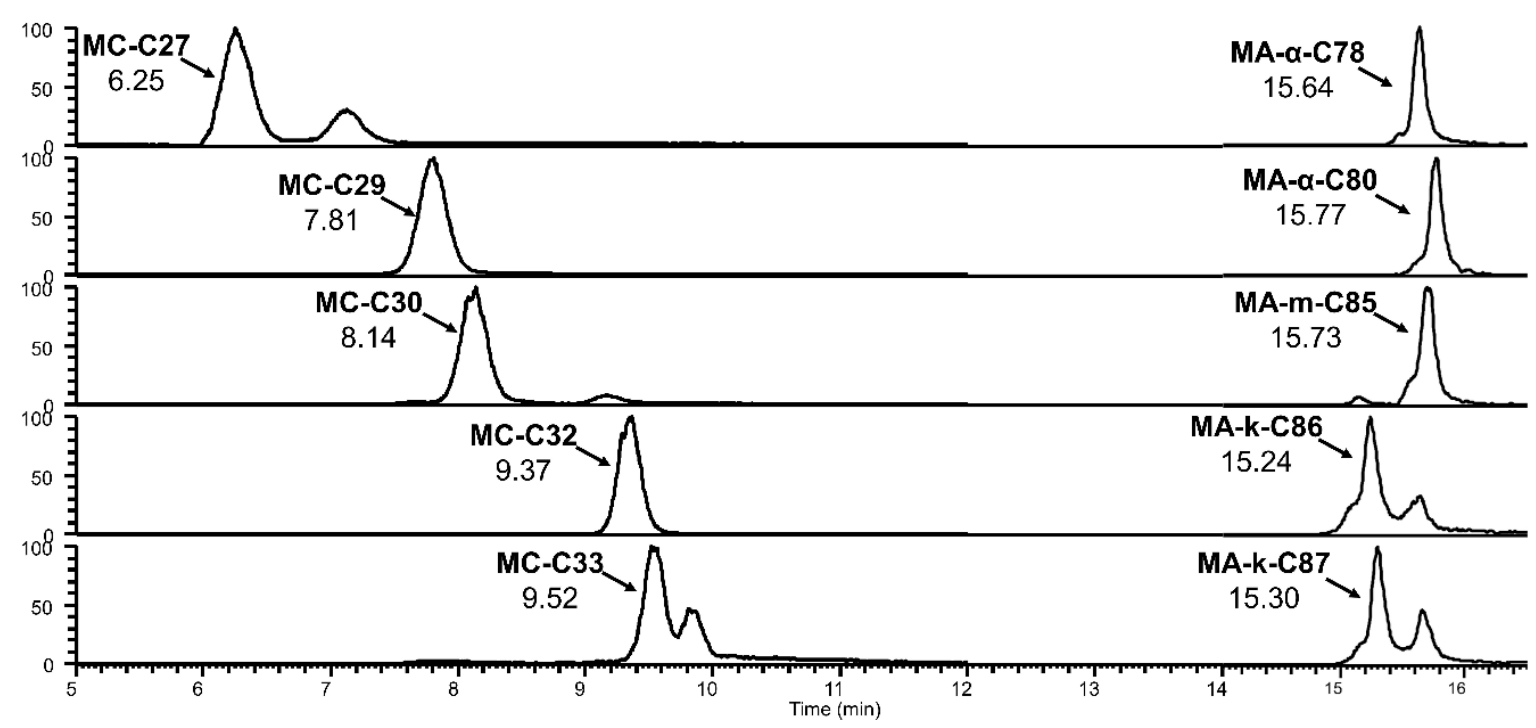

Figure 30: Combined EIC of MCs and MAs

As our aim was to develop a simple, but sensitive method for TB diagnostics on archaeological samples, we could not afford even a minimal carry-over during our measurements. However, there is a possibility that with further changes on the method we could have overcome with this issue, we chose to prioritise working only with MCs, since this lipid group is represented in a more limited group of mycobacteria (See Chapter 3.6).

\subsubsection{Comparison of APCI and ESI ion sources for mycocerosic acid detection}

First of all, we compared the efficiency of ESI and APCI ion sources for MC detection, the two most commonly used ion sources in the case of HPLC-MS based lipid analysis (Byrdwell, 2001; Nichols \& Davis, 2002; Willmann et al., 2011; Zhu et al., 2013; Horai et al., 2019). The literature implies that, although APCI is suitable to examine several kinds of 
lipids and provides a relatively simple mass spectrum, it can certainly lead to the degradation of labile lipids. In contrast, beside the extremely high-sensitivity and good reproducibility, which can be achieved with ESI, it provides a softer ionisation and minimises the undesired in-source fragmentation (Koivusalo et al., 2001; Crane et al., 2012; Han et al., 2012; Yunker et al., 2014; Wang et al., 2015b).

Initially, the MS parameters were tuned with both ion sources (Váradi et al., 2020). The optimisation was carried out in FIA mode with $50 \%$ of both eluent A and B. The basic settings of the spray voltage and S-lens voltage were $4 \mathrm{kV}$ and $60 \mathrm{~V}$, respectively. It was found that increasing the capillary temperature from $300{ }^{\circ} \mathrm{C}$ to $350{ }^{\circ} \mathrm{C}$ increased the intensity approximately to $150 \%$ (Figure 31.1 and 31.2). As the auxiliary gas temperature even in the previous measurements affected the ionisation positively, it was increased from $300{ }^{\circ} \mathrm{C}$ to $350{ }^{\circ} \mathrm{C}$. This change implied a $120 \%$ increase in the integrated area values (Figure 30.1 and 30.3). When both the capillary and the auxiliary gas temperature was set to $350{ }^{\circ} \mathrm{C}$ the intensity of the monitored peaks were doubled compared to the initial values (Figure 31.1 and 31.4). Next, the application of APCI as ion source had been tested. Despite of the high increase of the basic capillary temperature from $250{ }^{\circ} \mathrm{C}$ first to $350{ }^{\circ} \mathrm{C}$ (Figure 31.5 and 31.6) and then up to $400{ }^{\circ} \mathrm{C}$ only a very low rise of the intensity was observed (Figure 31.6 and 31.7), hence further optimisation steps did not seem to provide promising results. After finding the application of HESI ion source to be more effective, the S-lens voltage, was also optimised. Its increase from $60 \mathrm{~V}$ to $70 \mathrm{~V}$ caused approximately 1.3 times increase in the intensity (Figure 31.4 and 31.8). Considerable gain in the intensity was not gained by further increase of this parameter (Figure 31.8 and 31.9). With the optimal settings of the MS (capillary and the auxiliary gas heated to $350{ }^{\circ} \mathrm{C}$, the spray voltage set to $4 \mathrm{kV}$, the S-lens voltage set to $70 \mathrm{~V}$ ) the intensity of C27 MC grew with180\%, the final intensity of C29-C32 was approximately $300 \%$ higher. 


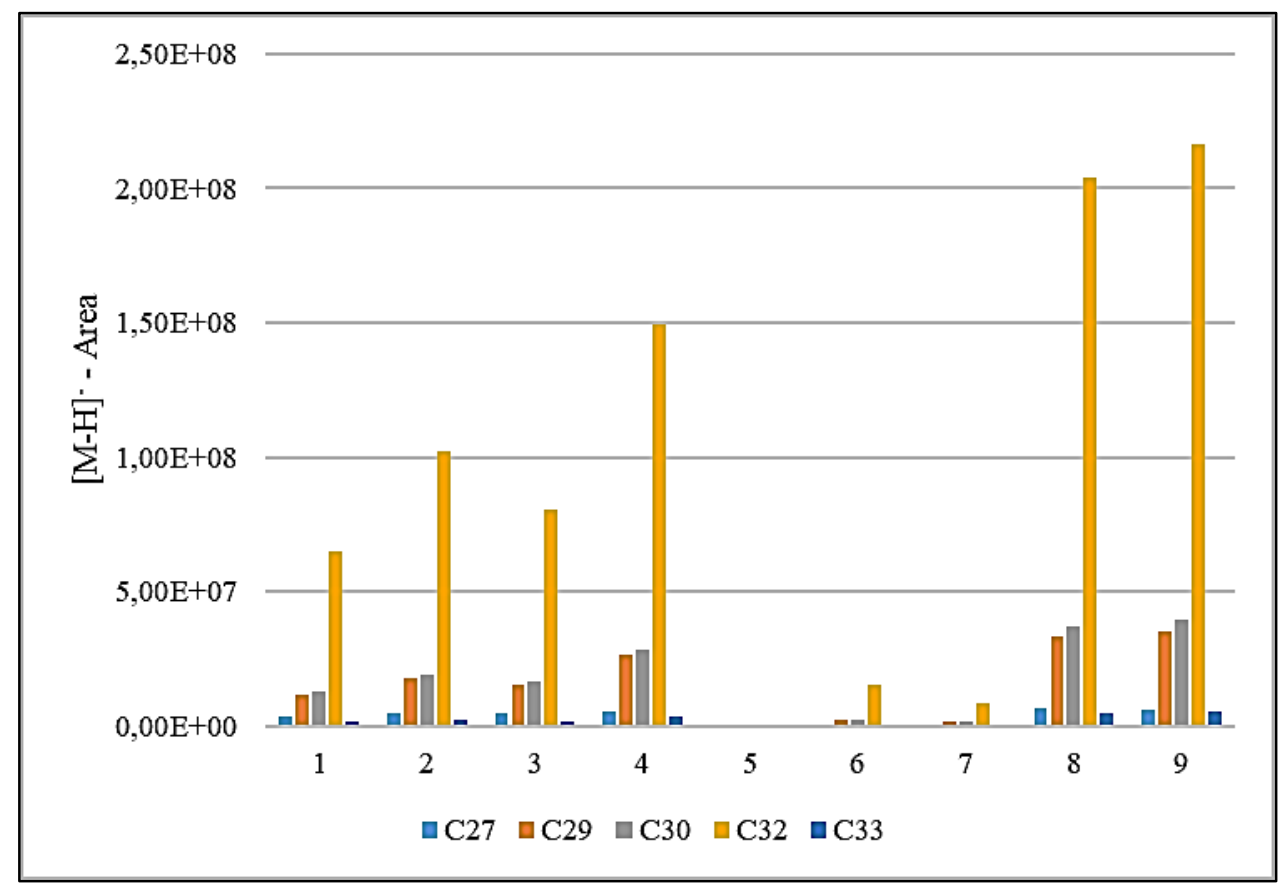

Figure 31: Comparison and optimisation of APCI and ESI ion sources

6.1.3.2 Confirmation of the mycocerosic acid peaks and the development of mycocerosic acids profiles from standard mycobacteria

After the retention times had been observed, with the application of the described gradient elution, the divert valve was set to switch to be open in the direction of the MS only from 5 to $15 \mathrm{~min}$ to avoid the contamination of the instrument (Váradi et al., 2020). During the evaluation, the detected MC peaks have been normalised to the peak with the highest area value. Beside the similarities with the observed elution patterns in the previously published methods (Redman et al., 2009; Lee et al., 2012; Donoghue et al., 2017), we compared the chromatogram of several mycobacateria (MTBC and NTM). Those peaks which were observed only in those strains (e.g. MTBC, M. kansasii), which are described as mycobacteria able to express mycocaerosates, but not in the other strains, were considered as MC peaks.

In the case of $M$. tuberculosis $\mathrm{H} 37 \mathrm{Rv}$ strain, the $\mathrm{C} 32$ (100\%) MC is the most abundant, followed by $\mathrm{C} 29$ (57\%) and $\mathrm{C} 30(50 \%)$ MCs, with $\mathrm{C} 27$ (9\%) and $\mathrm{C} 33$ (8\%) as minor components (Figure 32) (Váradi et al., 2020). The highest RSD was determined for the C27 MC (28\%), while C29 and C33 MCs showed 12\% and 5\% RSD, respectively; the lowest RSD values were observed for the C30 (3\%) and C32 MCs (0\%). 


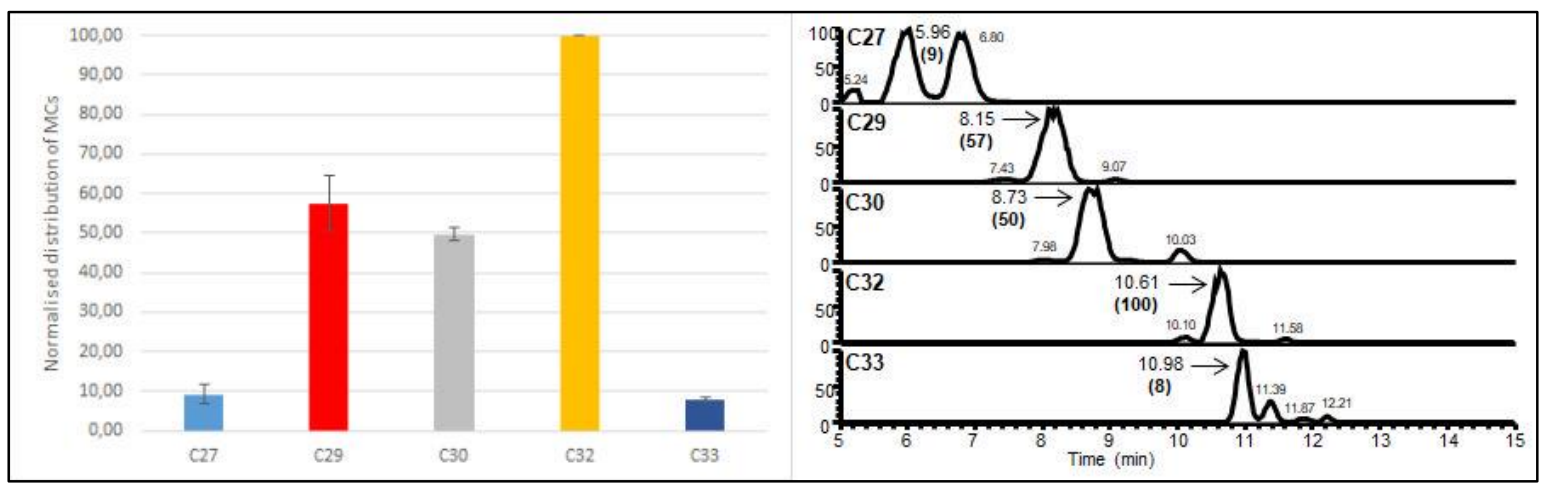

Figure 32: MC profile M. tuberculosis $\mathbf{H 3 7 R v}$

The MC profile of M. bovis (ATCC, NR-31210) was also established (Váradi et al., 2020). The $\mathrm{C} 29 \mathrm{MC}$ has been presented in the highest ratio (0\% RSD). It was followed by the $\mathrm{C} 27$ and C32 MCs with 30 and 28\% (10 and 20\% RSD, respectively). The least presented MCs were C30 and C33 MCs, and their area value was $21 \%$ and $2 \%$ of the highest peak (14 and 13\% RSD, respectively) (Figure 33).

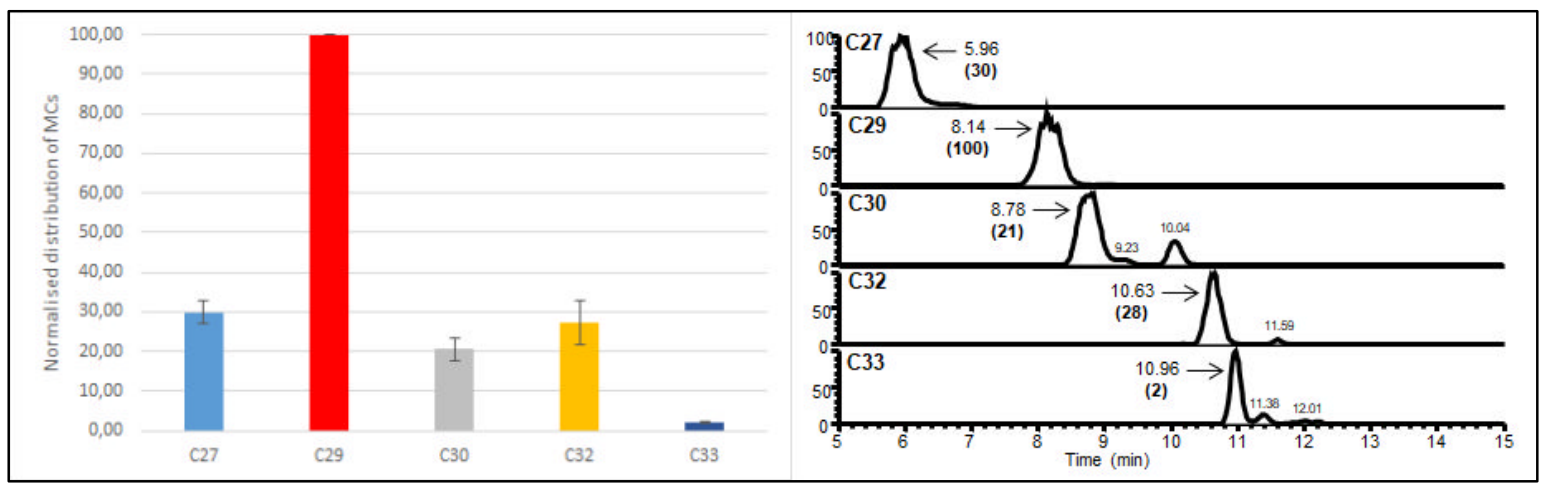

Figure 33: MC profile M. bovis (ATCC)

To give a generally applicable reference MC profile, the average $M$. tuberculosis profile was established by the examination of five MTBC strains deriving from patients (Váradi et al., 2020). The M. tuberculosis complex 1/8508/2014 strain has been excluded from the calculation of the average $M$. tuberculosis profile establishment, as its profile resembled that of the M. bovis strain provided from BEI Resources (Figure 33 and Figure 34 E) and with the published M. bovis values (Redman et al., 2009). The most well-marked difference of this strain is that C29 MC was most prominent (0\% RSD), while C32 was only $22 \%$ (18\% RSD). The C27 MC was 38\% (3\% RSD), C30 and C33 were 15\% and 0.1\% (23-63\% RSD), respectively 


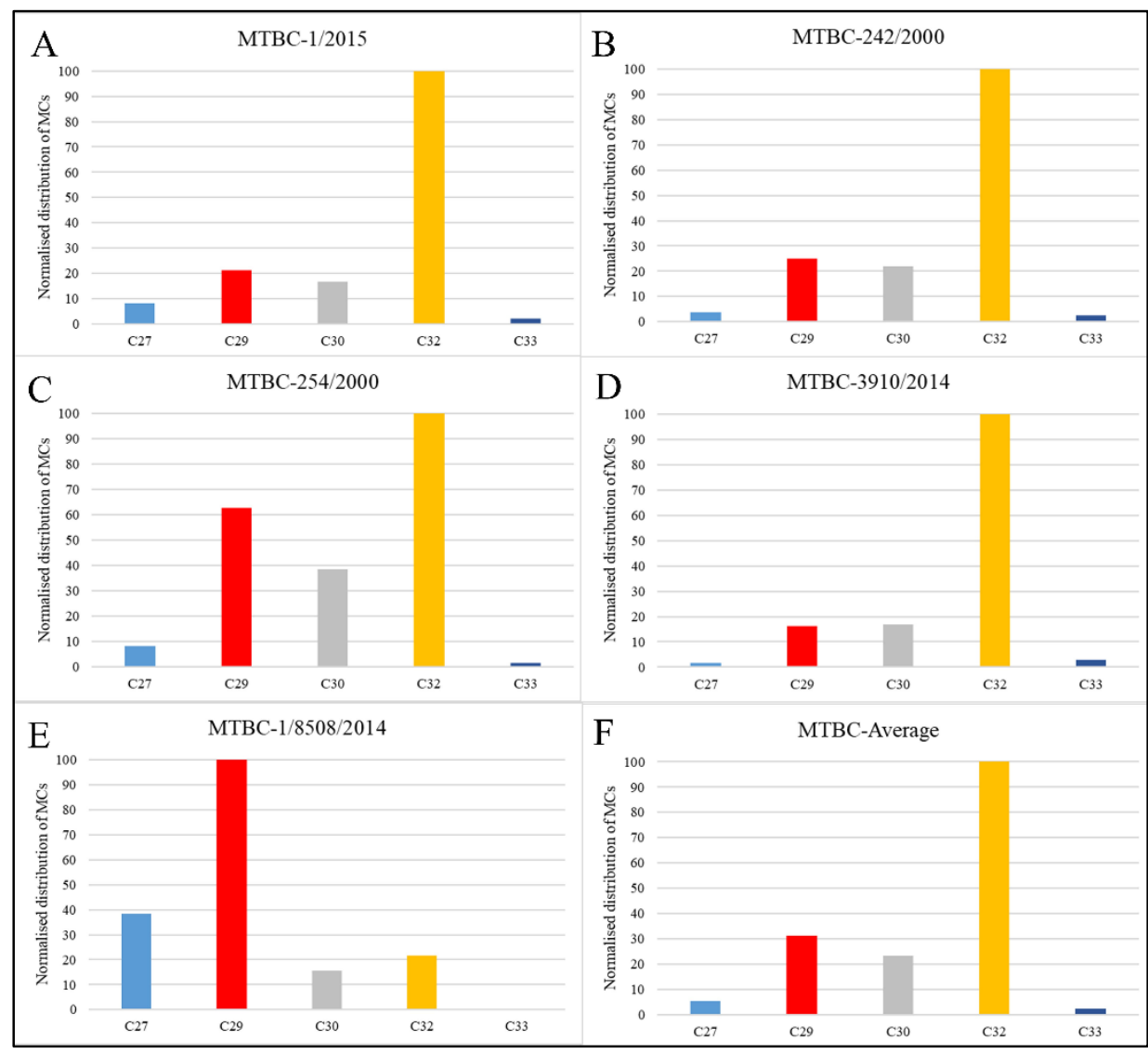

Figure 34: MC profiles of the analysed clinical MTBC samples

The rest of the analysed MTBC isolates provided rather similar profiles (Váradi et al., 2020). In every case C32 MC was the most prominent, while C29 and C30 MCs were present with similar distribution in the case of MTBC-1/2015, MTBC-242/200 and MTBC-3910/2014 strains, with a slightly higher representation of C29 (Figure 34 A, B, D). The dominance of C29 MC was more expressed in the strain, MTBC-254/2000 (Figure 34 C). Regarding the average distribution $\mathrm{C} 29$ and $\mathrm{C} 30$ were represented in $31 \%$ and $23 \%$, respectively (Figure $34 \mathrm{~F})$. The $\mathrm{C} 33 \mathrm{MC}$ was observed in the lowest ratio in every cases, reaching only $2 \%$ of C32 in the calculated average profile. The relative proportions of these M. tuberculosis MCs are in general accord with previously published profiles (Redman et al., 2009; Minnikin et al., 1993). The observed EICs presented a similar pattern with those in those in M. tuberculosis H37Rv (Figure 32 and Figure 35). Within the $m / z$ range of C27 MC (409.40510) three peaks appeared in the case of M. tuberculosis H37Rv, MTBC-242/2000, MTBC-254/200 and MTBC-3910/2014 (Figure 35 B, C, D). During the comparison of all examined strains, the second peak was exclusively observed in mycobacterial strains expressing MC (Figure 35). In the mycolic acid profiling analysis two strains exhibited relevant differences, namely the MTBC-1/2015 and MTBC-1/8508/2014. The C27 MC peak appeared solitaire in MTBC- 
1/8508/2014 and M. kansasii-1959/2018 (similarly to the chromatogram of M. bovis ATCC, Figure 33), and was eluting along a later peak in MTBC-1/2015.
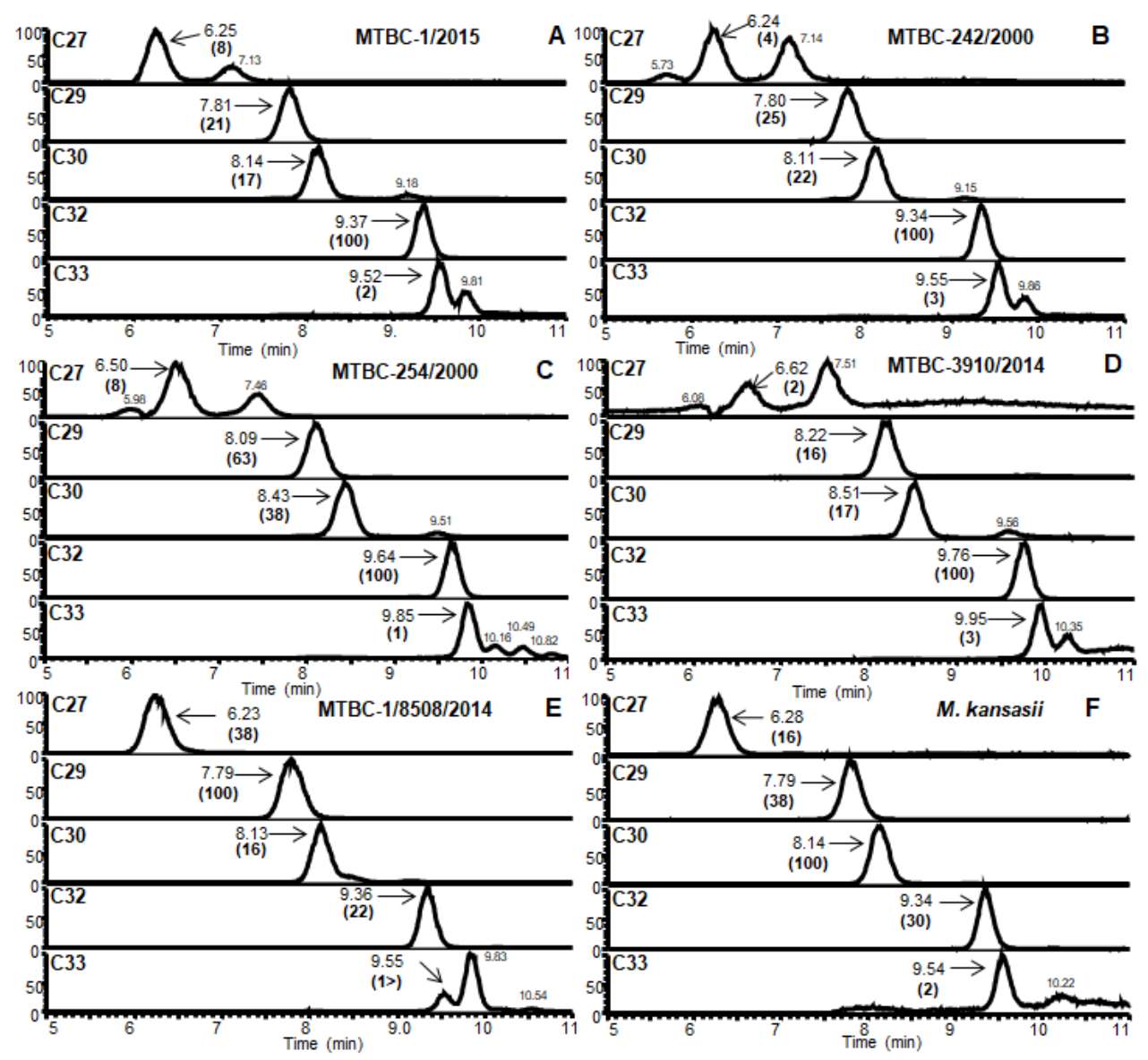

Figure 35: EIC of the analysed MTBC strains and M. kansasii-1959/2018

During the examinations of NTM isolates, in the case of $M$. kansasii-1959/2018, the C30 MC was recorded in the highest ratio (0\% RSD) (Váradi et al., 2020). It was followed by the C29 (38\%, 14\% RSD) and C32 MC (30\%, 7\% RSD), while the C27 and C33 MCs were presented in 16\% (2\% RSD) and 2\% (14\% RSD), respectively (Figure 36). 


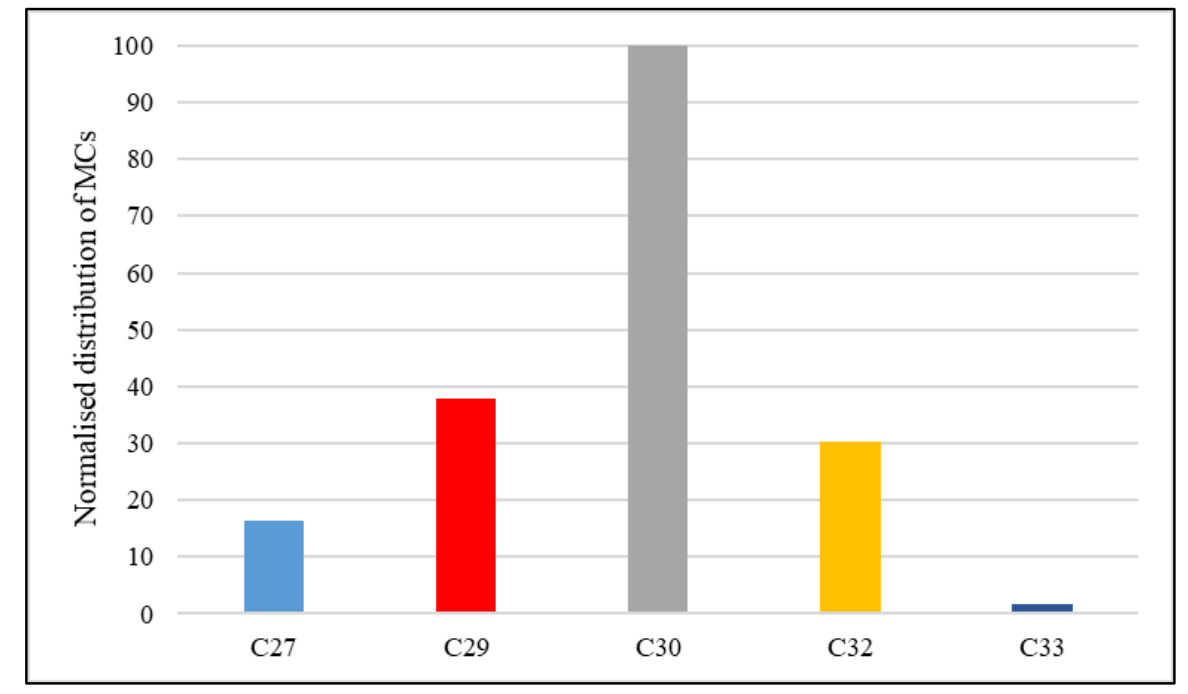

Figure 36: MC profile of M. kansasii 1959/2018

Among the rest of the NTM species (Figure 37), a peak co-chromatographing with C27 MC was seen in the M. avium strain, but the other monitored MCs were not detectable; the true identity of this component remains to be established (Váradi et al., 2020). The remainder of the examined NTM species did not show any traces of the monitored MCs (Figure 37). These results correlate well with previously published data, which point to the fact that MCs can be found only in the following species: M. tuberculosis, M. bovis, M. gastri, M. haemophilum, M. kansasii, M. leprae, M. marinum, and M. ulcerans (Redman et al., 2009; Minnikin et al., 1985; Daffé \& Lanéelle, 1988; Draper et al., 1983; Hartman et al., 1992; Minnikin et al., 1993). An extended study presenting a THM-GC-MS based method for the differentiation of $M$. tuberculosis from NTM species came to a similar result (Dang et al., 2013). In this study, the applied MC biomarkers have not been detected in the following NTM species: M. avium 16229/2018 (Figure 37 C), M. chelonae 16/2018 (Figure 37 D), $M$. intracellulare 7802/2017 (Figure 37 E), M. fortuitum 3/2018 (Figure 37 F), M. gordonae 389/2018 (Figure 37 G), M. abscessus 180/2018 (Figure 37 H) and M. chimaera 619/2018 (Figure 37 I). The MC profile from M. kansasii 1959/2018 (Figure 36) includes significant proportions of C32 MCs, which correlates with its perceived role as an ancestor of the broad M. tuberculosis complex (Donoghue et al., 2017; Minnikin et al., 2015; Jankute et al., 2017). 

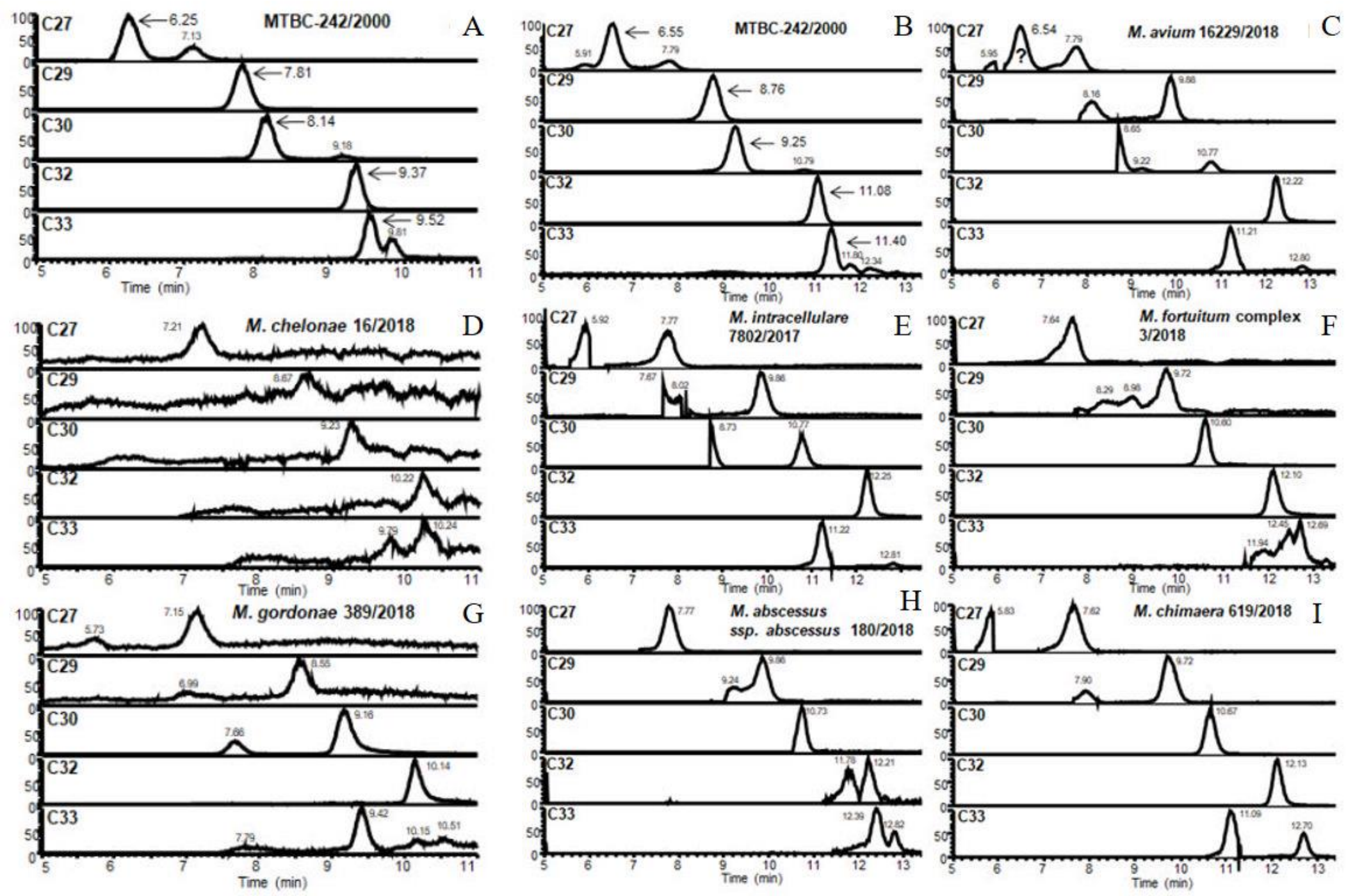

Figure 37: EIC of the analysed NTM species along with EIC of MTBC for reference 


\subsubsection{Profiles of mycocerosic acids from the analysed Vác mummies}

With the application of the optimised method, which was used to establish the previously introduced profiles we tested our method on samples derived from Vác mummies, diagnosed with TB infection on the base of aDNA analysis (Váradi et al., 2020). The targeted MCs were recorded in SIM. The individual EICs are grouped on Figure 38 and Figure 40).
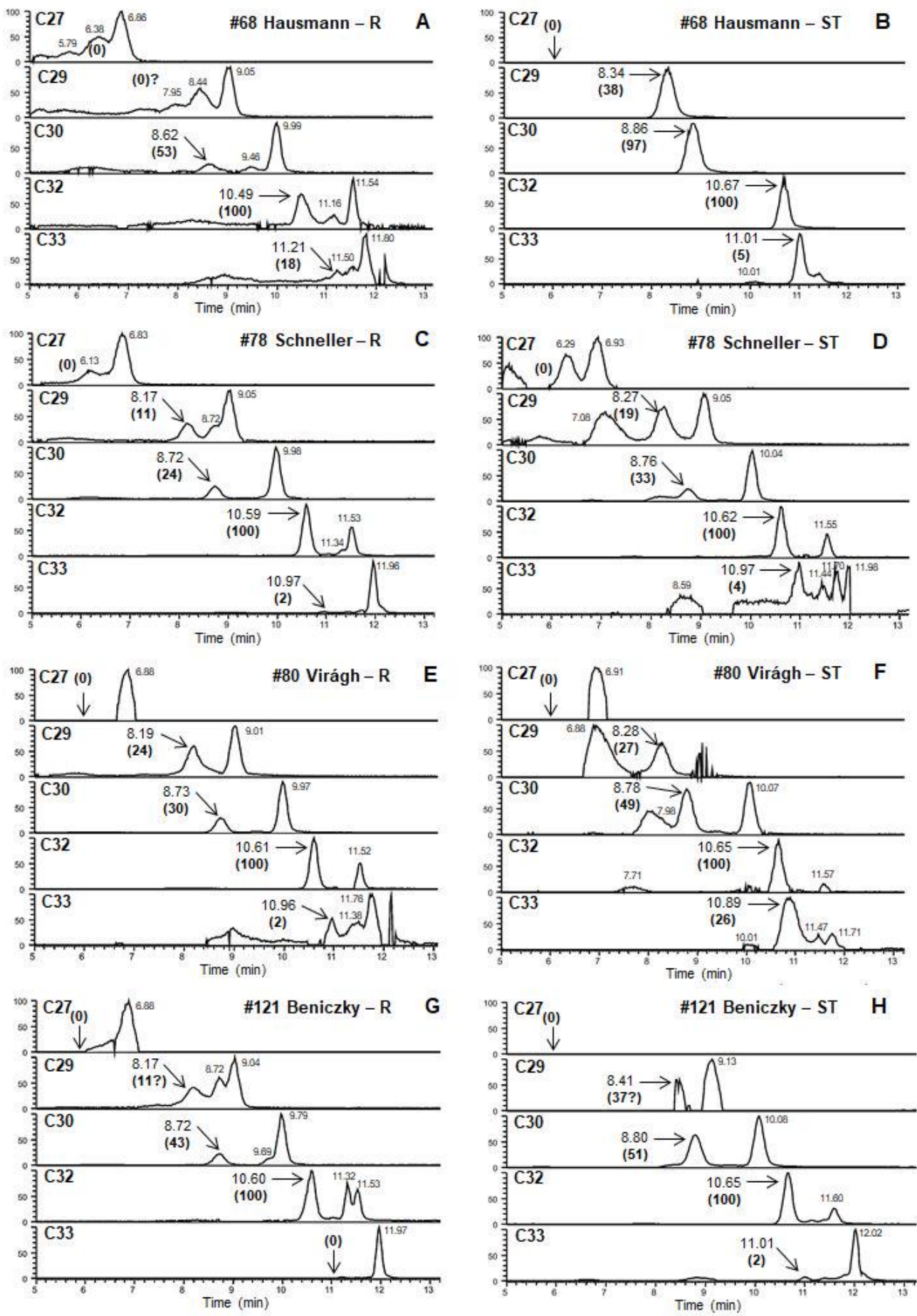

Figure 38: The EICs of the positive Vác mummy samples 
The lipid profiles observed for the extracts of both rib and soft tissue samples from four consistent cases are shown in Figure 38. The M. tuberculosis C27 MC minor component (Figure 32 and Figure 34) was not detected in any of these extracts (Váradi et al., 2020). The results for the samples taken from the remains of Terézia Hausmann (\#68) were positive. In the MC profile for the soft tissue sample (Figure 38 B and Figure 39), the main C32 peak was accompanied by major C29, C30 and minor C33 peaks. The rib sample (Figure $38 \mathrm{~A}$ and Figure 39) had clear main C32 and major C30; however, any minor C33 was indistinct and the area for expected C29 was obscured. The positive rib and soft tissue profiles, from the remains of Anna Schneller (\#78) (Figure 39 A, B and Figure 38), both had the expected main C32 and major C29 and C30, but the minor C33 was not so clear. Both types of samples belonging to Erzsébet Virágh (\#80) (Figure 38 E, F and Figure 39) proved to be also positive, with clear C29, C30, C32 and C33 peaks being detected; however, the C33 peak in case of the soft tissue sample was overrepresented, a rather broad peak suggesting overlap with an unknown component (Figure $38 \mathrm{~F}$ and Figure 39). The rib and soft tissue of László Beniczky (\#121) (Figure 38 G, H and Figure 39) exhibited clear MC peaks for C30 and C32 mycocerosates, with little C33. The C29 signals were questionable, as the rib peak (Figure $38 \mathrm{G}$ and Figure 39) was not fully resolved, and in the soft tissue extract, the peak shape was atypical (Figure $38 \mathrm{H}$ and Figure 39).

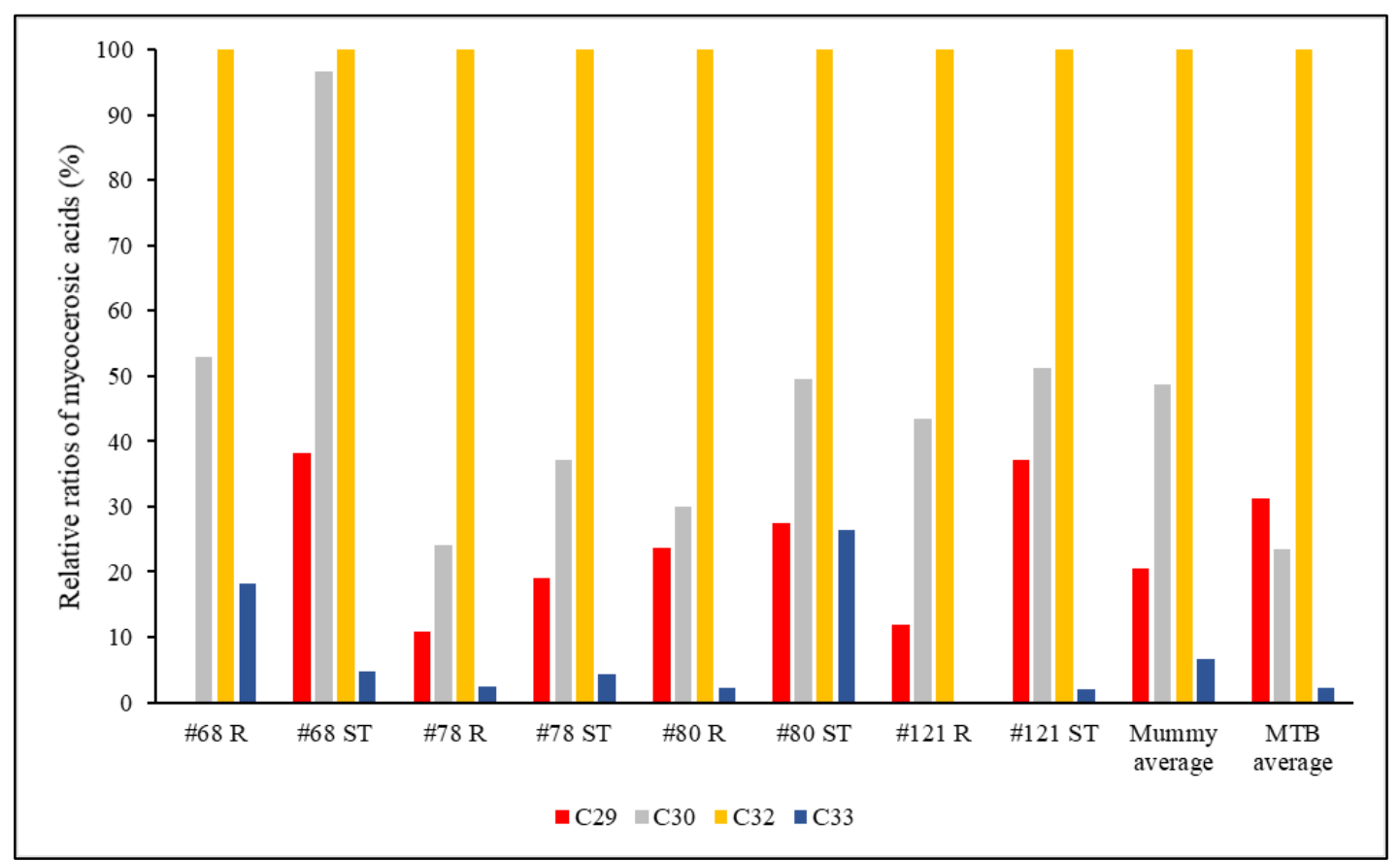

Figure 39: MC profiles of the positive mummy samples 
The soft tissue samples of Gáspár Steitel (\#25) did not contain detectable MCs (Figure 40 B), while the rib extracts (Figure 40 A) showed very weak indecisive results for C30 and C32 MCs (Váradi et al., 2020). Conversely, the rib extracts from Terézia Damiani (\#79) (Figure $40 \mathrm{C}$ ) were devoid of MCs, but the soft tissue samples (Figure $40 \mathrm{D}$ ) provided barely discernible indications of C30 and C32 MCs. These inconclusive results cannot be regarded as a positive indication of tuberculosis in these mummies, but the fact that the very weak signals are for two of the principal MC components (C30 and $\mathrm{C} 32)$ may be useful signposts.

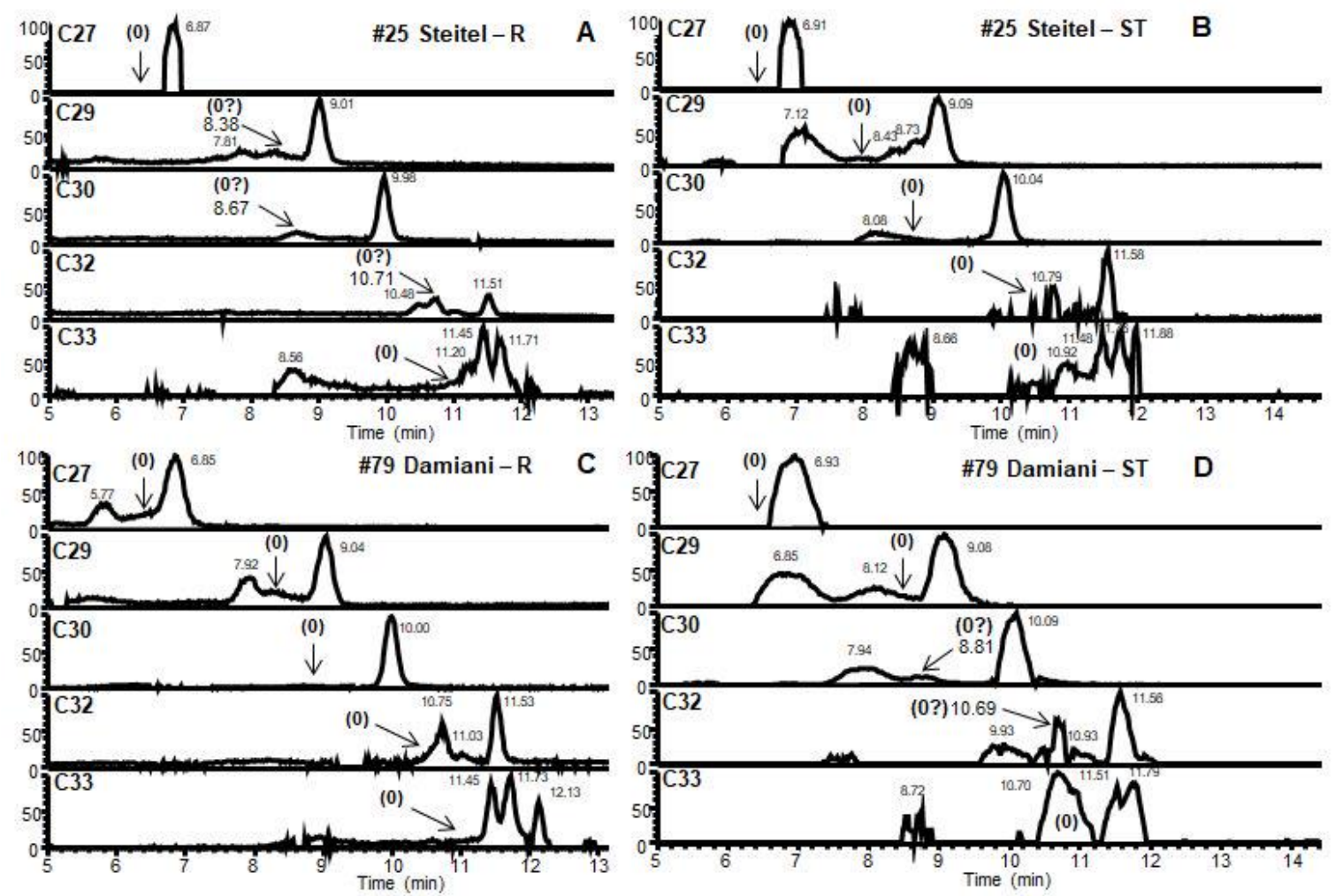

Figure 40: The EICs of the negative Vác mummy samples

It can be concluded that when the three most presented C32, C30, and C29 MCs, with a principal amount of the $\mathrm{C} 32$ component, are found in archaeological samples, infection with M. tuberculosis is indicated (Váradi et al., 2020). Compliance with these requirements was recorded for the rib and soft tissue samples from Terézia Hausmann (\#68), Anna Schneller (\#78), Erzsébet Virágh (\#80) and László Beniczky (\#121) (Figure 5). However, the cases of Gáspár Steitel (\#25) and Terézia Damiani (\#79) (Figure 6) cannot be recognised as positive. In most cases, $\mathrm{C} 32 \mathrm{MC}$ was presented at least in a double ratio compared to the $\mathrm{C} 30 \mathrm{MC}$, except for case \#68 soft tissue, where the C30 and C32 mycocerosates were found in almost equal ratios (Figure $5 \mathrm{~B}$ ). Only traces of C33 mycocerosic acid were detected from both sample types of \#68, \#78, and \#80, as well as from the soft tissue sample of \#121, so the 
diagnostic use of this biomarker is limited for ancient tuberculosis. However, C33 and C34 mycocerosic acids have established value for recognising ancient Mycobacterium leprae, including joint tuberculosis-leprosy cases (Masson et al., 2015).

The selected individuals were examined initially by Fletcher and colleagues (Fletcher et al., 2003). In their analysis the presence of the 123-bp region of the IS6110 insertion sequence was screened. Samples providing positive samples were further analysed for silent point mutations of the gyrA 95 and katG 463 genes. Based on the detected silent point mutatations the differentiation of the infectious agents into three genotypes was carried out, following the work of Sreevatsan and colleagues (1997). In a later study the mummy of Terézia Hausmann was the subject of the first metagenomic determination by Chan and colleagues (2013), followed by a more comprehensive whole genomic study by Kay and co-workers (2015). Correlations of lipid and DNA biomarkers are summarised below for each individual mummy.

Terézia Hausmann (\#68). Positive MC profiles (Figure 38 A, B) matched the result of the DNA-based analysis; traits of gyrA 95 and $k a t G 463$ genes were found in the chest, with the silent point mutations characteristic to the group 3 genotype of $M$. tuberculosis (Fletcher et al., 2003). Metagenomic analysis found a multiple infection by more than one $M$. tuberculosis strain (Chan et al., 2013). Later investigations of a left lung specimen revealed that one of the $M$. tuberculosis strains belonged to sublineage 4.1.2.1, also known as the Haarlem lineage (Kay et al., 2015; Stucki et al., 2016), and the other one belonged to the 4.7 sublineage (Kay et al., 2015). The latter one is recently identified as the part of sublineage 4.10 (Stucki et al., 2016).

Anna Schneller (\#78). Amplification of the katG 463 codon from a rib sample by Fletcher and colleagues (2003) gave good support to the positive MC profiles (Figure 38 C, D). Based on its sequence, the infectious agent could belong to the group 2 or group 3 genotype. A later phylogenetic analysis revealed that the $M$. tuberculosis strain also belonged to the current MTBC sublineage 4.10 (Kay et al., 2015; Stucki et al., 2016).

Erzsébet Virágh (\#80). Similarly, Fletcher and colleagues (2003) found that, based on the silent point mutations of gyrA 95 and katG 463 genes, the infectious agent belongs to the group 3 genotype. The full genomic examinations by Kay and colleagues (2015) also revealed that the $M$. tuberculosis strain belongs to the 4.1.2.1 sublineage. All this evidence backs the positive coherent MC profiles (Figure $38 \mathrm{E}, \mathrm{F}$ ). 
László Beniczky (\#121). The MC profiles had slightly decreased positivity due to questionable C29 peaks (Figure $38 \mathrm{G}, \mathrm{H}$ ), but diagnostic PCR products have been amplified earlier from a pleura sample, with a silent point mutation pattern belonging to group 3 (Fletcher et al., 2003). Positive sequencing data of a rib sample showed a mixed infection of M. tuberculosis sublineage 4.10, sublineage 4.3 and Lineage 4 (Kay et al., 2015; Stucki et al., 2016).

Gáspár Steitel (\#25). Unfortunately, the MC profiles were essentially negative (Figure 40 A, B) in contrast with the previous detection of M. tuberculosis complex DNA (Fletcher et al., 2003; Kay et al., 2015). The first PCR based aDNA examinations, using a sample taken from the left chest, detected only the traits of katG 463 gene, with the silent point mutation suggesting that the infectious agent belonged to group 2 or 3 (Fletcher et al., 2003). The later metagenomic examinations of tissue from the abdomen region determined that the $M$. tuberculosis strain belongs to the Lineage 4 (Kay et al., 2015)

Terézia Damiani (\#79). In this case, the monitored MC biomarkers could not be detected (Figure 40 C, D). However, Fletcher and colleagues (Fletcher et al., 2003) amplified the fragment of the katG 463 gene in the sample taken from the pelvis region of this individual and found the silent point mutation characteristic of group 2 and 3. Metagenomic analyses have not been performed on extracts of this mummy.

Overall, in four of the six mummies studied, there is good correlation of mycocerosate profiles (Figure 39) with positive ancient DNA analyses. In the two cases lacking significant mycocerosate presence (Figure 40), but with good indications of aDNA biomarkers, the discrepancy may be due to differences in the samples investigated. Mummified individuals provide a much greater choice of areas for sampling than in skeletons without soft tissue. Even though the cases of Gáspár Steitel and Terézia Damiani (Figure 40) were deemed negative, the very weak signals observed in Figure 40 A, D could be sufficient to encourage investigation of a wider range of samples from these mummies. 


\section{CONCLUSIONS}

A variety of analytical methods have been employed for mycobacterial lipid biomarker profiling (Donoghue et al., 2017). Fluorescence HPLC is well-developed for the analysis of mycolic acids and phthiocerols (Hershkovitz et al., 2008; Lee et al., 2012; Donoghue et al., 2017). Furthermore, there is only one isolated case of direct mass spectrometric detection of M. tuberculosis free mycolic acids from a Neolithic lesions vertebra (Borowska-Strugińska et al., 2014). Mass spectrometry, however, has been the basis of the analysis of ancient mycocerosic acids, using selected ion monitoring, negative ion-chemical ionisation GC-MS of pentafluorobenzyl ester derivatives (Redman et al., 2009; Lee et al., 2012; Donoghue et al., 2017). However, this method is a well-proven procedure, the popularity and availability of the necessary instrumentation have declined over the past two decades. Conversely, HPLC-MS facilities have become routine in biological and other analytical laboratories, thus our aim was to establish a lipid biomarker based HPLC-HRMS method, for TB diagnosis in historical human samples, as this instrumentation is available in many laboratories, and has the potential of a rapid, but sensitive and at the same time affordable measurement protocol.

The most important achievements of our study are summarized as follows:

1. The first step towards establishing a lipid biomarker based HPLC-HRMS method for TB diagnosis in historical human samples was the tuning of the applied HPLC and the MS parameters, for the efficient detection of mycolic acids and mycocerosic acids and the optimisation of the sample pre-treatment process. In the case of the MA detection method development 5 different eluent compositions were tested on the single quadrupole LCMS system, and 14 eluent compositions on the HPLC-Orbitrap MS system. The application of non-polar solvents is widespread in HPLC-MS based MA detection methods, which is most commonly chloroform (Bhamidi et al., 2011; Shui et al., 2012; Szewczyk et al., 2013; Borowska-Strugińska et al., 2014; Portevin et al., 2014). In our initial measurements on the single quadrupole LCMS system the application of chloroform seemed beneficial. The presence of increased chloroform concentration affected negatively the ionisation of MAs on the Orbitrap MS. With the application of heptane, as non-polar component we could increase the peak intensity, moreover we were able to establish a method for the separation and parallel detection 
of MAs and MCs. The MS parameters were optimised with 1 eluent composition on the single quadrupole LCMS system, and with the application of 2 eluent compositions on the HPLC-Orbitrap MS system for MA detection. MS parameters were tuned and with the application of 1 eluent composition for MC detection. During the optimisation of the MS parameters, the positive effect of the increased capillary and auxiliary gas temperature, as well as the increased capillary and S-lens voltage was observed. The intensity of the targeted peaks become higher regardless of the applied solvent composition. During the optimisation of the MC detection protocol APCI and ESI ion sources were compared, both commonly used in lipid detection (Byrdwell, 2001; Nichols \& Davis, 2002; Willmann et al., 2011; Zhu et al., 2013; Horai et al., 2019). For the detection of mycocerosic acids ESI has been observed as more efficient ion source, which is known to provide softer ionisation in contrast with the APCI (Yunker et al., 2014). As for the optimisation of the sample pre-treatment protocol of MA extraction the $\mathrm{KOH}$ concentration of the initial saponification mixture was tested. The comparison of $20 \%$ or $30 \% \mathrm{KOH}$ content did not presented any difference, however, further decrease to $10 \%$ resulted lower MA outcome. Beside the optimisation of $\mathrm{KOH}$ concentration, 5 different extraction solvents/solvent combinations were compared. The results suggested that nonetheless the application of non-polar solvents are needed for the extraction, the lowest polarity is not equal with the best efficiency.

2. With the application of the optimised methods, the development of lipid profile library, regarding both mycolcic and mycocerosic acids has been carried out. The MA profiles of 5 MTBC clinical isolates (MTBC-1/2015; MTBC-254/2000; MTBC-3910/2014; MTBC-242/2000; and MTBC-1/8508/2014) and 5 NTM clinical isolates (M. gordonae 389/2018, M. intracellulare 7802/2017, M. abscessus ssp. abscessus 180/2018, M. kansasii 1959/2018 and M. chelonae 16/2018) have been established. However, data regarding MA profiles of NTM species in the literature presents a higher variety (Song et al., 2009; Shui et al., 2011; Szewczyk et al., 2013), and our sample set is not adequate for statistical conclusions, with the low representation of oxygenated mycolates the differentiation of MTBC from NTM representatives seems possible with the application of lipid profiling via HPLC-MS, but the confirmation requires the extension of the library. The MC profile development included 5 MTBC clinical isolates (MTBC1/2015; MTBC-254/2000; MTBC-3910/2014; MTBC-242/2000; and MTBC1/8508/2014), M. tuberculosis H37Rv and M. bovis (ATCC) reference strains and 8 NTM clinical isolates (M. avium 16229/2018, M. chelonae 16/2018, M. intracellulare 
7802/2017, M. fortuitum 3/2018, M. gordonae 389/2018, M. abscessus sp abscessus 180/2018, M. chimaera 619/2018, M. kansasii 1959/2018). Among the representatives of MTBC in 4 out of 5 strains and in the case of $M$. tuberculosis H37Rv reference strain, the same tendency of MC distribution has been observed as the literature is suggesting for M. tuberculosis (Redman et al., 2009; Lee et al., 2012). One of the 5 strains presented a MC distribution more characteristic to M. bovis. Among the analysed NTM species only the profile of $M$. kansasii was established, as the remainder species are not expressing mycocerosates. The analysed $M$. avium strain presented a peak with the same retention time of C27 MC, which will need further investigation. Based on the observed profiles the detection of prominent C32 MC content, accompanied with significant C29 and C30 MC peaks were used as criteria for MTB diagnosis in the following analysis.

3. The efficiency of the established lipid biomarker based method was tested on a wellstudied collection of mummified human remains, namely on the Vác mummy collection. Regarding the MA detection, despite of the applied non-polar solvent composition the elution of MAs was not complete. We could not afford even a minimal carry-over during our measurements, hence only the MC method was tested on the mummy samples. In the case of four mummified individuals, profiles of characteristic M. tuberculosis MCs were recorded, but two other mummies did not yield diagnostic MC profiles. However, all the mummy samples had been found, previously, to be positive by aDNA examination, but the samples in this study were not identical with those used previously and the sampling site may affect the results. An extended study of confirmed cases, with multiple sampling sites of skeletal material and soft tissue, where available, is suggested to clarify the situation. The present results, however, provide further confirmation of widespread tuberculosis in the Vác mummies. The HPLC-ESI-MS method, developed for the detection of MCs, opens up a new avenue for the detection of ancient mycobacterial disease, encompassing both tuberculosis and leprosy and joint cases. Currently, the instrumentation required is available in many laboratories and technical developments are likely to reduce complexity and increase sensitivity and affordability. A particular advantage is that no chemical derivatisation of the particular lipid biomarkers is needed, the free acids being utilised. The method could be extended to include the related $M$. tuberculosis lipid biomarker, mycolipenic acid (Donoghue et al., 2017). However, in our method we could not overcome with the carry-over of MAs yet, involving new solvent compositions and testing new approaches for separation, a comprehensive protocol could be developed to add profiles of free mycolic acids 
(Borowska-Strugińska et al., 2014; Donoghue et al., 2017). In the well-established fluorescence HPLC procedure, the recognition of diagnostic mycolate profiles requires extensive derivatisation and sequential reverse and normal phase HPLC analyses (Hershkovitz et al., 2008; Donoghue et al., 2017). In contrast, in a single selected ion monitoring HPLC run, all the diagnostic mycolic acid data are collected and are available for further processing.

\section{SUMMARY}

The diagnosis of ancient mycobacterial disease in archaeological material requires a multidisciplinary approach. Most of the TB-related bony lesions are the result of extrapulmonary TB (Aufderheide \& Rodríguez-Martín, 1998; Marcsik et al., 1999, 2009; Pálfí \& Marcsik, 1999; Hershkovitz et al., 2002; Maczel, 2003; Ortner et al., 2003; Paja et al., 2015; Pálfi \& Molnár, 2009; Pálfi et al., 2012; 2015; Mariotti et al., 2015; Spekker, 2018; Spekker et al., 2018; Spekker et al., 2020a; Spekker et al., 2020b), which was registered only in 16\% of all incident cases in 2019 (WHO, 2020). Moreover, only a low proportion of extrapulmonary TB develops specific and detectable bony lesions. Macromorphological paleopathological studies lead necessarily to the underestimation of ancient TB prevalence. For the better estimation of TB incidence in past populations an array of specific biomarkers can be brought into play to confirm initial skeletal diagnoses and search in the soft tissue of suspected cases (Donoghue et al., 2017). The pioneering application of whole-genome sequencing (Chan et al., 2013) has opened the prospect of obtaining comprehensive information regarding the nature and number of infecting M. tuberculosis strains (Kay et al., 2015; Bos et al., 2014). Confidence in aDNA diagnoses has been greatly reinforced by recording profiles of specific lipid biomarkers, which are particularly robust and accessible (Donoghue et al., 2017). Initial lipid targets were the C70 to C90 mycolic acids (Gernaey et al., 1998; Donoghue et al., 1998; Hershkovitz et al., 2008), but the range was broadened to include the mycocerosic and C27 mycolipenic acids (Redman et al., 2009; Lee et al., 2012) and phthiocerols (Lee et al., 2012).

A variety of analytical methods have been employed for mycobacterial lipid biomarker profiling (Donoghue et al., 2017). Fluorescence HPLC is well-developed for the analysis of mycolic acids and phthiocerols (Hershovitz et al., 2008; Lee et al., 2012; Donoghue et al., 
2017). There is only one isolated case of direct mass spectrometric detection of $M$. tuberculosis free mycolic acids from a Neolithic lesions vertebra (Borowska-Strugińska et al., 2014). Mass spectrometry, however, has been the basis of the analysis of ancient mycocerosic acids, using selected ion monitoring, negative ion-chemical ionisation GC-MS of pentafluorobenzyl ester derivatives (Redman et al., 2009; Lee et al., 2012; Donoghue et al., 2017). However, this method is a well-proven procedure, the popularity and availability of the necessary instrumentation have declined over the past two decades. Conversely, HPLC-MS facilities have become routine in biological and other analytical laboratories.

However, in our initial analysis the HPLC-MS analysis carried out with a single quadrupole analyser was efficient for the detection of the most characteristic MAs of MTBC, its sensitivity and specificity was far behind compared to those of achieved with the application of Orbitrap MS.

Finding the proper standards for a method development is always crucial. Unfortunately, to purchase commercially available authentic MA standard was not possible from any companies represented in Hungary. We were able to start our work with MA standard kindly provided by David E. Minnikin. With the help of the provided standard the verification of the targeted peaks was carried out with two approaches. Firstly, on the recorded mass spectrum beside finding the selected targeted peaks, further MAs have been detected in the cases of all the three MA classes. The three MA classes are naturally occurring with at least five homologues (Minnikin et al., 2015). Both the targeted and not targeted MAs could be included in series of molecules with 28 Dalton differences (two-carbon unit), characteristic to the homologous series of MAs, due to their biosynthesis pathway (Takayama et al., 2005). With the application of PRM measurements the two most characteristic fragments were the 365.35767 and the 395.38901, identified as the C24 and C26 $\alpha$-alkyl chain, respectively. These fragments have been observed by other authors (Szewczyk et al., 2013; Song et al., 2009; Bhamidi et al., 2011; Lehmann et al., 2018).

During the optimisation procedures with the increased capillary and auxillary gas temperature, as well as with the increased capillary and S-lens voltage, the intensity of the targeted peaks become higher regardless of the applied solvent composition. The combined application of these changes could increase the measured area values with up to $300 \%$ in some cases. The application of high temperature and capillary voltage was described by Szewczyk and colleagues (2013), as well, although the method described by Bhamidi and 
colleagues (2011) involved the drying gas and vaporiser temperature set only to $300{ }^{\circ} \mathrm{C}$ and $200{ }^{\circ} \mathrm{C}$, however the aim of their study was not the diagnostics, but to reveal a detailed the spatial organisation of $M$. tuberculosis and M. leprae cell wall.

In contrast with aDNA, obviously there is no option for amplifying the extracted lipid biomarkers, thus the efficiency of the extraction is surpassingly important. Overviewing several pre-treatment protocols, a very diverse range of descriptions can be found in studies covering MA detection methods from sputum and bacterial samples (Hershkovitz et al., 2008; Song et al., 2009; Bhamidi et al., 2011; Sui et al., 2012; Szewczyk et al., 2013; Teramoto et al., 2015; Yoshino et al., 2018). The diversity is partly originated from the numerous detection techniques applied for the MA measurements. However, in these methods there are some commonly used steps, such as the saponification and the acidification before the extraction into the non-polar organic solvent. In our measurements first the concentration of $\mathrm{KOH}$ in the mixture used during saponification was tested. The application of $20 \%$ or $30 \%$ did not presented any difference, however further decrease to $10 \%$ resulted lower MA outcome. The application of hexane isomer mixture resulted higher efficiency regarding the extraction of $\alpha$ - and methoxy-MA specimens, while affected negatively the efficiency of the extraction of keto-MAs, hence extraction 3 times with toluene was followed by one additional extraction step with hexane. This extraction set up seemed to be the most efficient in further comparisons, as well. The results suggested, that nonetheless the application of non-polar solvents are needed for the extraction, the lowest polarity is not equal with the best efficiency.

As a reference for later investigations the development of a mycobacterial MA profile library has been started, including the profile of MTBC-1/2015, MTBC-254/2000, MTBC3910/2014, MTBC-242/2000, MTBC-1/8508/2014, M. gordonae 389/2018, $M$. intracellulare 7802/2017, M. abscessus ssp. abscessus 180/2018, M. kansasii 1959/2018 and M. chelonae 16/2018. The $\alpha-\mathrm{C} 78$ was found to be the most abundant MA in all the included MTBC strains. The second highest representation varied between the $\alpha-\mathrm{C} 80$ and $\mathrm{m}-\mathrm{C} 85$, moreover m-C87 was also highly represented. The $\alpha-C 82, \mathrm{~m}-\mathrm{C} 88, \mathrm{k}-\mathrm{C} 87$ and m-C89 MAs were also represented in higher, than 5\% in most of the analysed MTBC strains. Comparing our results to those published by Borowska-Strugińska and colleagues (2014) and Bhamidi and colleagues (2011) similar distribution patterns were described. Regarding the summarised values of individual MA-s based in their type the $\alpha$-MAs were represented in the highest ratio in the involved MTBC strains, ranging between $40 \%-50 \%$, however in one 
exception, the highest summarised area values belonged to methoxy-MA specimens, which were slightly less represented in the other 4 strains, adding up to approximately $40 \%$ of the overall area values. The least represented MA type was the keto-MA in every cases. The observed distribution of MA classes was very similar to those published by other authors, with the application of various methods (Hershkovitz et al., 2008; Bhamidi et al., 2011; Szewczyk et al., 2013). The MA profiles of the involved NTM strains draw a more diverse picture. Similar to the analysed MTBC strains the most abundant MA specimen was the $\alpha$ C78 MA. MAs with higher alkyl-chain and oxygenated MAs were less represented in most of NTM strains. In comparison with MTBC the distribution of $\alpha$-MAs in general was much higher in NTM species, than the oxygenated keto- or methoxy-MAs. In our measurements the oxygenated MA-s of $M$. intracellulare, M. abscessus and $M$. chelonae showed different distribution to the published profiles (Minnikin \& Brennan, 2020), which implies the need of further investigation. However, the published MA profiles of NTM species presents differences from our results (Song et al., 2009; Shui et al., 2011; Szewczyk et al., 2013; Minnikin \& Brennan, 2020), with the low representation of oxygenated mycolates the differentiation of MTBC from NTM representatives seems possible with the application of lipid profiling via HPLC-MS.

The application of non-polar solvents is widespread in HPLC-MS based MA detection methods, which is most commonly chloroform, but some methods are including hexane due to its even lower polarity (Bhamidi et al., 2011; Shui et al., 2012; Szewczyk et al., 2013; Borowska-Strugińska et al., 2014; Portevin et al., 2014). In our initial measurements we selected the application of chloroform as non-polar component of solvent composition. The optimisation to find the best chloroform concentration showed, that the presence and increase of chloroform affects negatively the ionisation of MAs on the Orbitrap MS. With the application of heptane, as non-polar component we could increase the peak intensity, moreover we were able to establish a method for the separation and parallel detection of MAs and MCs. Unfortunately, despite of the applied non-polar solvent composition the elution of MAs was not complete, especially in the case of MAs with longer alkyl-chain length (e.g. k-C86, k-C87). As our aim was to develop a simple, but sensitive method for TB diagnostics on archaeological samples, we could not afford even a minimal carry-over during our measurements. However, there is a possibility that with further changes on the method we could have overcome with this issue, we chose to prioritise working only with MCs, since this lipid group is represented in a more limited group of mycobacteria (Redman et al., 2009), 
and did not show the sign of any carry-over. During the comparison of ESI and APCI as ion source, the optimisation of MS parameters for better ionisation of MCs presented similar results to those for the detection of MAs, e.g. increased temperature of capillary and auxiliary gas and increased capillary and S-lens voltage were beneficial.

In the development of MC based detection method, a MC profile library was established. Among the representatives of MTBC in 4 out of 5 strains the $\mathrm{C} 32 \mathrm{MC}$ was the most prominent, while C29 and C30 MCs were present with similar distribution, and C33 MC was observed in the lowest ratio, similarly to those detected in the M. tuberculosis H37Rv reference strain. The same tendency has been reported with the application of different methods (Redman et al., 2009; Lee et al., 2012). The one strain excluded from the establishment of the average MC profile of MTB presented a MC distribution more characteristic to M. bovis. Among the analysed NTM species (M. avium 16229/2018, M. chelonae 16/2018, M. intracellulare 7802/2017, M. fortuitum 3/2018, M. gordonae 389/2018, M. abscessus sp. abscessus 180/2018, M. chimaera 619/2018, M. kansasii 1959/2018) only the profile of M. kansasii was established, as the remainder species are not expressing mycocerosates. Comparing the chromatograms of MTBC and M. kansasii to the observed EICs of the other mycobacteria proved the selectivity of the applied method, as no co-eluting peaks were observed, with one exception. The analysed M. avium strain presented a peak with the same retention time of $\mathrm{C} 27 \mathrm{MC}$, which will need further investigation. The optimised method seemed to provide an easy and quick way to confirm TB-infected cases among archaeological human remains. This hypothesis was tested on samples taken from Vác mummies, which were earlier defined TB-positive based on aDNA results.

In the case of four mummified individuals, profiles of characteristic M. tuberculosis MCs were recorded, but two other mummies did not yield diagnostic MC profiles. However, all the mummy samples had been found, previously, to be positive by aDNA examination, but the samples in this study were not identical with those used previously and the sampling site may affect the results. An extended study of confirmed cases, with multiple sampling sites of skeletal material and soft tissue, where available, is suggested to clarify the situation. The present results, however, provide further confirmation of widespread tuberculosis in the Vác mummies.

The HPLC-ESI-MS method, developed for the detection of MCs, opens up a new avenue for the detection of ancient mycobacterial disease, encompassing both tuberculosis and leprosy 
and joint cases. Currently, the instrumentation required is available in many laboratories and technical developments are likely to reduce complexity and increase sensitivity and affordability. A particular advantage is that no chemical derivatisation of the particular lipid biomarkers is needed, the free acids being utilised. The method could be extended to include the related M. tuberculosis lipid biomarker, mycolipenic acid (Donoghue et al., 2017). However, in our method we could not overcome with the carry-over of MAs yet, involving new solvent compositions and testing new approaches for separation, a comprehensive protocol could be developed to add profiles of free mycolic acids. As noted above, free mycolic acids were successfully profiled in a Neolithic tuberculosis case (BorowskaStrugińska et al., 2014) and this study demonstrates the powerful diagnostic capability of direct mass spectrometry. In the well-established fluorescence HPLC procedure, the recognition of diagnostic mycolate profiles requires extensive derivatisation and sequential reverse and normal phase HPLC analyses (Hershkovitz et al., 2008; Donoghue et al., 2017). In contrast, in a single selected ion monitoring HPLC run, all the diagnostic mycolic acid data are collected and are available for further processing.

\section{9 ÖSSZEFOGLALÓ}

A történeti korokban előforduló mikobakteriális megbetegségek diagnózisa multidiszciplináris megközelítést igényel. A letöbb tuberkulózissal (tbc) összefüggésbe hozható csonttani elváltozást a betegség extrapulmonális megjelenési formái eredményezik (Aufderheide \& Rodríguez-Martín, 1998; Marcsik et al., 1999, 2009; Pálfi \& Marcsik, 1999; Hershkovitz et al., 2002; Maczel, 2003; Ortner et al., 2003; Paja et al., 2015; Pálfi \& Molnár, 2009; Pálfi et al., 2012; 2015; Mariotti et al., 2015; Spekker, 2018; Spekker et al., 2018; Spekker et al., 2020a; Spekker et al., 2020b). A WHO becslései szerint extrapulmonális tbct mindössze az esetek 16\%-ában regisztráltak 2019-ben (WHO, 2020). Továbbá az egyébként is viszonylag alacsony arányban megjelenő extrapulmonális tbc-s eseteknek csak egy kis százalékában alakulnak ki specifikus és detektálható csontelváltozások, ezért a makroszkópos paleopatológiai vizsgálatok önmagukban alábecsülik a tbc prevalenciáját a történeti embertani anyagok analízise során. A korábban élt népességek között fellelhető tbcs esetek számának pontosabb becsléséhez ezért a makroszkópos vizsgálatok mellett, a csontokból és lágyszövetekből kivonható, specifikus biomarkerek azonosítására is szükség 
van, melyek segítségével a morfológiai alapon gyanúsnak ítélt esetek igazolhatók (Donoghue et al., 2017). A teljes genom szekvenálás alkalmazásával (Chan et al., 2013), olyan új utak nyíltak meg a paleopatológiai vizsgálatokban, melyek segítségével átfogó információ nyerhető a fertőzést kiváltó $M$. tuberculosis törzs típusát és azok számát illetően (Bos et al., 2014; Kay et al., 2015). Az aDNS vizsgálatok eredményei jól kiegészíthetők még a lipid biomarker profilok vizsgálatával is (Donoghue et al., 2017). Kezdetben a 70-90 szénatom számú mikolsavak (MA) analízisét vonták be a vizsgálatokba (Gernaey et al., 1988; Donoghue et al., 1998; Hershkovitz et al., 2008), majd a célzott lipid biomarkerek sora a mikocerozátokkal és a C27-es mikolipenáttal (Redman et al., 2009; Lee et al., 2012), valamint a phthiocerolokkal bővült (Lee et al., 2012). A mikobakteriális lipid biomarker profilok kimutatásához többféle analitikai módszert írtak le (Donoghue et al., 2017). A mikolsavak és phthiocerolok kimutatásához első sorban egy jól karakterizált HPLC-FLD módszert alkalmaznak a paleopatológiai vizsgálatok során (Hershovitz et al., 2008; Lee et al., 2012; Donoghue et al., 2017). Egy esetben találhatunk példát a M. tuberculosis eredetü mikolsavak direkt tömegspektrométeres kimutatására (Borowska-Strugińska et al., 2014), melyhez a felhasznált minta egy neolit korból származó tbc-vel érintett csigolyából származott. A mikocerozát profilon alapuló tbc-diagnosztika a paleopatológiában egy gázkromatográfiás elválasztást követő tömegspektrometriás kimutatáson alapul (Redman et al., 2009; Lee et al., 2012; Donoghue et al., 2017). Ez a módszer a mikocerozátokat pentafluorobenzil észter formában, negatív ion módban kémiai ionizációs eljárással vizsgálja. Habár ez az eljárás jól kidolgozott és megfelelően validált, a szükséges müszerek egyre kevesebb laboratóriumban elérhetök, miközben a HPLC-MS alkalmazása rutinná vált a biológiai és egyéb analitikai alkalmazásokban.

Bár a munka kezdeti szakaszában, a HPLC-MS vizsgálatok során egy egyszeres quadrupole analizátorral a MTBC legkarakterisztikusabb mikolsav típusait sikeresen azonosítottuk, a későbbiekben használt Orbitrap MS érzékenysége és specificitása messze meghaladta a korábbi müszerét.

Módszerfejlesztések során elengedhetetlen a megfelelő standard alkalmazása. A kereskedelmileg elérhető, autentikus mikolsav standard beszerzése azonban egyetlen Magyarországon képviseltetett cégnél sem lehetséges, így munkánkat David E. Minnikin által biztosított mikolsav standard felhasználásával kezdtük meg. A standard segítségével a detektált csúcsokat két módon azonosítottuk. Elsőként a megfigyelt tömegspektrumon a kiválasztott csúcsokon felül további mikolsavakat detektáltunk mind a három mikolsav 
csoport (alfa-, keto- és metoxi-mikolátok) esetében. Minden mikolsav csoporthoz legalább 5 homológ mikolsav tartozik (Minnikin et al., 2015), melyek a mért $\mathrm{m} / \mathrm{z}$ értékeik szerint besorolhatók voltak 28 Dalton (két metil-csoport) különbséget mutató sorozatokba. Ez a tömegkülönbség a mikolsav homológokra jellemző, azok bioszintézis útvonalát követi (Takayama et al., 2005). A mikoslavakat ezután PRM üzemmódban vizsgáltuk, melynek segítségével a két legjellemzőbb, mások által is gyakran detektált, az $\mathrm{m} / z 365.35767$ és 395.38901 fragmenseket azonosítottuk, melyek a C24 és C26 $\alpha$-alkil láncnak felelnek meg (Szewczyk et al., 2013; Song et al., 2009; Bhamidi et al., 2011; Lehmann et al., 2018).

Az optimalizációs lépések során a kapilláris és a szárítógáz hőmérsékletének, valamint a kapilláris és az S-lencse feszültségének növelésével a csúcsok mért intenzitása is emelkedett az alkalmazott eluens összetételtől függetlenül. Az említett változtatások alkalmazásával néhány esetben az integrált csúcsterület értékek háromszorosukra növekedtek. Szewczyk és munkatársai (2013) szintén magas hőmérsékletet és kapilláris feszültséget alkalmaztak, míg Bhamidi és munkatársai (2011) alacsonyabb szárító- $\left(300{ }^{\circ} \mathrm{C}\right)$ és porlasztógáz $\left(200{ }^{\circ} \mathrm{C}\right)$ hőmérséklettel dolgoztak, habár fontos megjegyezni, hogy tanulmányuk célja nem diagnosztikai jellegü volt, hanem a $M$. tuberculosis és $M$. leprae sejtfal térbeli felépítését vizsgálták.

Az aDNS vizsgálatokkal ellentétben természetesen nincs lehetőség a kivont lipid biomarkerek felsokszorosítására, így az extrakció hatékonysága kiemelten fontos. A mikolsavak vizsgálatával foglalkozó tanulmányok rendkívül változatos mintaelőkészítési módszereket alkalmaznak mind a köpet, mind a baktérium minták esetében (Hershkovitz et al., 2008; Song et al., 2009; Bhamidi et al., 2011; Sui et al., 2012; Szewczyk et al., 2013; Teramoto et al., 2015; Yoshino et al., 2018). A változatosság részben a számos különböző MA detektálási technikából ered, azonban ezek a módszerek tartalmaznak néhány általánosan előforduló lépést, ilyenek például a szappanosítás, savanyítás és az azt követő extrakció apoláris oldószerekkel. Az optimalizálási munka során elöször a szappanosító oldat kálium-hidroxid koncentrációját vizsgáltuk. A $20 \%$ és 30\% kálium-hidroxidot tartalmazó oldatok hatásfoka nem mutatott különbséget, azonban a concentráció 10\%-ra történő csökkentése negatívan befolyásolta a mikolsav kihozatalt. Az extrakciós oldószerek tesztelése során a hexán izomer elegy alkalmazása növelte az alfa- és metoxi-mikolátok extrakciójának hatékonyságát, viszont csökkentette a keto-mikolátok kihozatalát, ezért az eredetileg alkalmazott három ismétlésben történő toluolos extrakció került kiegészítésre egy negyedik, hexános extrakciós lépéssel. További összehasonlítások során szintén ez az eljárás 
bizonyult a leghatékonyabbnak. Az eredmények alapján úgy tünik, hogy bár az apoláris oldószerek alkalmazása szükséges az extrakcióhoz, ezek alkalmazása nem jelent egyet a jobb hatékonysággal.

A módszer optimalizálása után megkezdtük egy mikobakteriális mikolsav könyvtár építését a következő klinikai izolátumok felhasználásával: MTBC-1/2015, MTBC-254/2000, MTBC-3910/2014, MTBC-242/2000, MTBC-1/8508/2014, M. gordonae 389/2018, M. intracellulare 7802/2017, M. abscessus ssp. abscessus 180/2018, M. kansasii 1959/2018 és M. chelonae 16/2018. Az összes MTBC törzs esetében a legnagyobb arányban előforduló mikolsav az $\alpha$-C78 volt. A második legnagyobb mennyiségben előforduló mikolsavak az $\alpha$ C80 és a m-C85 voltak, továbbá a m-C87 mikolsav is magas arányban volt jelen. Az $\alpha$-C82, m-C88, k-C87 és a m-C89 mikolsavak magasabb, mint 5\%-os arányban fordultak elő. Az általunk megfigyelt mikolsav eloszlás a korábban közölt profilokhoz (Borowska-Strugińska et al., 2014; Bhamidi et al., 2011) hasonló képet mutatott. Az egyes mikolsavak csúcsterület értékeit típusonként is összegeztük, azok egymáshoz viszonyított arányát is vizsgáltuk. Az 5 klinikai MTBC izolátum vizsgálata során 4 esetben az alfa mikolsavak voltak jelen a legnagyobb arányban, mintegy 40\%-50\%-ban, míg egy törzs esetében a metoxi-mikolátok voltak a legnagyobb relatív mennyiségben, melyek a többi törzs esetében az alfamikolsavaknál kisebb arányban, körülbelül 40\%-ban voltak jelen. Legkisebb mennyiségben a keto-mikolsavakat detektáltuk az összes vizsgált törzsben. A megfigyelt típusonkénti mikolsav eloszlás megfelel a más szerzők által leírtaknak, a különböző alkalmazott kimutatási módszerektől függetlenül (Hershkovitz et al., 2008; Bhamidi et al., 2011; Szewczyk et al., 2013). A nem-tuberkulotikus Mycobacterium fajok mikolsav eloszlása sokkal változatosabb képet mutatott. A MTBC törzsekhez hasonlóan, itt is az $\alpha$-C78 mikolsav volt jelen a lenagyobb mennyiségben, azonban a hosszabb alkil-lánccal rendelkező alfa-mikolátok, valamint a keto- és metoxi-mikolsavak kisebb mennyiségben voltak jelen. A MTBC törzsekkel összehasonlítva az alfa-mikolsavak magasabb részarányban jelentek meg a keto- és metoxi-mikolátokhoz képest az NTM fajokban. Habár a nem-tuberkulotikus Mycobacterium fajok mikolsav profiljait illetően az irodalmi adatoktól eltérő eredményt kaptunk a metoxi- és keto-mikolsavak esetében (Song et al., 2009; Shui et al., 2011; Szewczyk et al., 2013; Minnikin \& Brennan, 2020), azok alacsony arányával a MTBC fajok megkülönböztetése az NTM fajoktól HPLC-MS módszerrel végzett lipid profilozással lehetségesnek tünik. 
Az apoláris oldószerek használata széles körben elterjedt a HPLC-MS alapú mikolsav kimutatási módszerek között, melyek közül leggyakrabban kloroformot, illetve néhány esetben a még kevésbé poláris hexánt alkalmazzák eluens összetevöként (Bhamidi et al., 2011; Shui et al., 2012; Szewczyk et al., 2013; Borowska-Strugińska et al., 2014; Portevin et al., 2014). A kezdeti méréseink során mi is a kloroform alkalmazása mellett döntöttünk, mint nem poláris eluens komponens. A megfelelő kloroform koncentráció kiválasztására irányuló mérések során azonban azt tapasztaltuk, hogy az Orbitrap MS esetében a kloroform jelenléte, illetve koncentrációjának növelése negatívan befolyásolja a mikolsavak ionizációját. A heptán, mint apoláris eluens összetevő alkalmazásával a detektált csúcsok intenzitása növekedett, valamint egy olyan grádiens elúciós módszert tudtunk létrehozni, melyben a mikocerozátok és mikolsavak elváltak egymástól, és egyidejűleg vizsgálhatók voltak. Annak ellenére, hogy az általunk keresett lipid biomarkerek jól elváltak egymástól, az alacsony polaritású eluens elegy ellenére sem volt teljes a mikolsavak elúciója, főként a hosszabb alkil-láncú mikolsavak esetén (pl.: k-C86, k-C87). Mivel a célunk az volt, hogy egy egyszerü, de érzékeny módszert hozzunk létre, amely a tbc diagnosztikai célú paleopatológiai vizsgálataiban alkalmazható, ezért a minták közötti minimális mikolsav átszennyezést sem engedtük meg a mérések során. Noha a módszer további változtatásával valószínűleg ez a probléma a későbbiekben megoldható lesz, úgy döntöttünk, hogy egylőre a mikocerozátok mérését részesítjük előnyben, mivel ezek a lipidek kevesebb Mycobacterium fajban vannak jelen (Redman et al., 2009), és egyértelmű választ adnak a fertőzés jelenlétére. A mikocerozát kimutatási módszer optimalizálása során az ESI és APCI ionforrások kerültek összehasonlításra, valamint az MS paraméterek beállításánál a mikolsav módszerben tapasztaltakhoz hasonló eredményre jutottunk (magasabb kapilláris és porlasztógáz hőmérséklet, valamint magasabb S-lencse és kapilláris feszültség szintén intenzitásnövekedést okozott).

A mikocerozát alapú kimutatási módszer esetében, szintén egy lipid könyvtár felépítésével folytattuk munkát. Az 5 vizsgált klinikai MTBC izolátum közül négyben, illetve a $M$. tuberculosis $\mathrm{H} 37 \mathrm{Rv}$ standard törzs esetében a C32-es mikocerozát volt jelen a legnagyobb mennyiségben, a C29-es, valamint C30-as mikocerozát egymással közel azonos mennyiségben volt kimutatható, míg a legkisebb intenzitást a C27-es és a C33-as mikocerozátok mutatták. Az irodalmi adatokban az általunk megfigyelt eloszláshoz hasonló eredményekkel találkozhatunk az eltérő módszerek ellenére (Redman et al., 2009; Lee et al., 2012). Egy klinikai MTBC törzset kizártunk a MTB-ra jellemző átlag mikocerozát eloszlás 
számításából, mivel annak mikocerozát profilja jobban korrelált a referencia $M$. bovis törzs esetében megfigyeltéhez. A vizsgált NTM fajok közül (M. avium 16229/2018, M. chelonae 16/2018, M. intracellulare 7802/2017, M. fortuitum 3/2018, M. gordonae 389/2018, M. abscessus sp. abscessus 180/2018, M. chimaera 619/2018, M. kansasii 1959/2018) a M. kansasii mikocerozát profilja volt megállapítható, mivel a többi vizsgált NTM faj sejtfala nem tartalmaz mikocerozátokat. Összehasonlítva a MTBC és M. kansasii extrahált ion kromatogramjait a többi vizsgált Mycobacterium fajnál megfigyeltekével a módszer szelektivitása bebizonyosodott, valamint egy kivételtől eltekintve nem tapasztaltunk koelúciót más komponensekkel. A vizsgált $M$. avium törzs esetében a C27-es mikocerozáttal megegyező tömegü és retenciós idejü csúcsot detektáltunk, ami további vizsgálatokat tesz szükségessé. Az optimalizált módszer alkalmasnak tűnt az archeológiai mintákban a tbc fertőzés könnyü és gyors kimutatására. Ennek bizonyítására, a módszert olyan Váci múmiákból származó mintákon teszteltük, melyek esetében a tbc fertőzést korábban aDNS vizsgálatokkal megállapították.

A vizsgáltba bevont mumifikálódott egyének közül 4 esetében $M$. tuberculosis-ra jellemző mikocerozát profilt rögzítettünk, míg 2 egyénböl származó minták vizsgálata negatív eredményt adott. Korábban az összes vizsgált egyén tbc-pozitívnak bizonyult az aDNS vizsgálatok alapján, fontos azonban megjegyezni, hogy az általunk vizsgált minták nem azonosak a korábban használtakkal és a mintavétel helye erősen befolyásolhatja a vizsgálatok eredményét. Egy nagy mintaszámú vizsgálat, melynek során a tbc-pozitív egyénekből számos mintavételi hely bevonásával történne szürés, a későbbiekben segíthetné mintavételezéssel járó roncsolás csökkentését, valamint a miénkhez hasonló összehasonlító vizsgálatok kivitelezését. A fent említett eltérés ellenére kijelenthető, hogy eredményeink további megerösítéssel és adatokkal szolgálnak a Váci múmiák között széles körben elterjedt tbc fertőzésről.

A kifejlesztett HPLC-ESI-MS módszer új utat nyit a mikocerozátok kimutatásában, mellyel a mikobakteriális fertőzések a történeti anyagokban is detektálhatók, magában foglalva nem csak a tuberkulotikus, de a leprás megbetegedéseket is, illetve azok ko-infekciós megjelenését. Napjainkban a kivitelezéshez szükséges műszerezettség sok laboratóriumban megtalálható és további technikai fejlesztéssel az eljárás komplexitása és költsége tovább csökkenthető, míg érzékenysége növelhető. A módszer nagy elönye, hogy a célzott lipidek kimutatása nem igényel kémiai származékképzést, a szabad lipidek önnmagukban detektálhatók. A későbbiekben tervezzük a módszer bővítését, a C27-es mikolipenát 
bevonásával, ami a pentaacil-trehalózok M. tuberculosis-ra jellemző specifikus acilösszetevője (Donoghue et al., 2017). Bár módszerünkben egyelőre nem oldottuk meg a mikolsavak maradéktalan elúcióját, új eluensek és új megközelítési módok bevonásával egy átfogó, kombinált módszer létrehozása valószínünek tünik. Ahogy a fentebb ismertetett példa mutatja egy neolit lelőhelyről származó humán tbc-s eset diagnosztikája kapcsán, a szabad mikolsavak direkt HPLC-MS kimutatása egy elérhető megközelítés. A paleopatológiában elterjedtebben alkalmazott HPLC-FLD módszer érzékenysége és pontossága több ízben bizonyított (Hershkovitz et al., 2008; Donoghue et al., 2017), a diagnosztikus mikolsav profil felvételéhez hosszadalmas származékképzési eljárás, valamint egymást követő RP- és NP-HPLC elválasztás szükséges. Ezzel ellentétben egy egyszerü HPLC-MS módszer alkalmazásával a diagnosztikus mikolsavak detektálása egy gyorsabb és egyszerübb lehetőséget kínálhat. 


\section{ACKNOWLEDGEMENTS}

I have received a great deal of support and assistance throughout my work, and writing of this dissertation.

First of all, I would like to express my gratitude to my supervisors, Dr. habil. György Pálfi and Dr. András Szekeres, for all the help and patience during my research and thesis writing, I am very grateful for their endless support and guidance. I am also grateful for Prof. Dr. Csaba Vágvölgyi, to the head of the Department of Microbiology for providing a workplace, where I could carry out my research.

I would like to express my heartfelt gratitude to Prof. David E. Minnikin, who honoured me with his advices and guidance, and also provided us the needed cell and mycolic acid standard material at the beginning of our work. This dissertation would have never been written without Dr. Zsolt Bereczki, who introduced me to the field of biological anthropology and has been helping me since my undergraduate studies.

I would like to extend my sincere thanks to all my colleagues and friends from the Department of Biological Anthropology, Dr. Erika Molnár, Dr. Olga Spekker, Dr. William Berthon, Balázs Tihanyi, Kitty Király, Luca Kis, János Rovó. Their personal and professional support always kept me going towards my goal. I am also very greatful to my colleagues from the Microbiology Department, Dr. Mónika Varga, Dávid Rakk, Gábor Endre for their countless advices.

I would like to thank the contribution in the analysis of the Vác mummy samples to Dr. Ildikó Pap, Szikossy Ildikó from the Department of Anthropology, Hungarian Natural History Museum and Dr. Albert Zink and Dr. Frank Maixner from the Institute for Mummy Studies, Eurac Research Centre.

I am very grateful to Dr. Gabriella Terhes, Dr. Edit Urbán and Dr. Burián Katalin from the Institute of Clinical Microbiology for providing me the used bacterial cells.

I gratefully acknowledge the financial support of the National Research, Development and Innovation Office (Hungary) (grant number: K 125561) and the support of GINOP (grant number: GINOP-2.3.3-15-2016-00006, and GINOP-2.3.2-15-2016-00012). 
I can not express my appretiation to Leo Jon Langlois, Tímea Gyevi-Nagy, Rebeka UrbánSzolnoky, Klaudia Kacsó, Bettina Bálint and Dr. Júlia Varga for all their support, cheering and patience. Last but not least I am extremely grateful to my family, László Váradi, Márta Káldi, Andrea Márta Váradi and Marianna Katalin Váradi, who were on my side in the hard times and who always believed in me.

I would like to dedicate this dissertation to my mother, Márta Káldi and my grandparents, József Káldi and Irén Aczél-Szabó, who are gone but always with me. 


\section{REFERENCES}

Abrahams KE, Besra GS. (2016) Mycobacterial cell wall biosynthesis: a multifaceted antibiotic target. Parasitology 145(2): 116-133. DOI: 10.1017/S0031182016002377.

Ahmad S. (2011) Pathogenesis, immunology, and diagnosis of latent Mycobacterium tuberculosis infection. Clin Dev Immunol. 2011: 814943. DOI: 10.1155/2011/814943.

Akram SM, Saleh D. (2020) Mycobacterium chelonae. In: StatPearls. StatPearls Publishing, Treasure Island (FL). Last update: August 13, 2020.

Alderwick LJ, Harrison J, Lloyd GS, Birch HL. (2015) The Mycobacterial Cell WallPeptidoglycan and Arabinogalactan. Cold Spring Harb Perspect Med. 5: a021113. DOI: 10.1101/cshperspect.a021113.

Alexander KA, Laver PN, Michel AL, Williams M, van Helden PD Warren RM, van Pittius NCG. (2010) Novel Mycobacterium tuberculosis Complex Pathogen, M. mungi. Emerg Infect Dis. 16(8): 1296-1299. DOI: 10.3201/eid1608.100314.

Alexander KA, Laver PN, Williams MC, Sanderson CE, Kanipe C, Palmer MV. (2018) Pathology of the Emerging Mycobacterium tuberculosis Complex Pathogen, Mycobacterium mungi, in the Banded Mongoose (Mungos mungo). Vet Pathol. 55(2): 303309. DOI:10.1177/0300985817741730.

Alexander KA, Sanderson CE, Larsen MH, Robbe-Austerman S, Williams MC, Palmer MV. (2016) Emerging tuberculosis pathogen hijacks social communication behavior in the groupliving banded mongoose (Mungos mungo). mBio. 7(3): e00281-16. DOI:10.1128/mBio.00281-16.

Allen AR. (2017) One bacillus to rule themall? - Investigating broad range host adaptation in Mycobacterium bovis. Infect Genet Evol. 53:68-76. DOI: 10.1016/j.meegid.2017.04.018.

Aranaz A, Cousins D, Mateos A, Domínguez L. (2003) Elevation of Mycobacterium tuberculosis subsp. caprae Aranaz et al. 1999 to species rank as Mycobacterium caprae comb. nov., sp. nov. Int J Syst Evol Microbiol. 53(6): 1785-1789. DOI: 10.1099/ijs.0.025320 .

Aranaz A, Liébana E, Gómez-Mampaso E, Galán JC, Cousins D, Ortega A, Blázquez J, Baquero F, Mateos A, Súarez G, Domínguez L. (1999) Mycobacterium tuberculosis subsp. caprae subsp. nov.: a taxonomic study of a new member of the Mycobacterium tuberculosis 
complex isolated from goats in Spain. Int J Syst Bacteriol. 49(3): 1263-1273. DOI: 10.1099/00207713-49-3-1263.

Aufderheide AC, Rodríguez-Martín C. (1998) The Cambridge encyclopedia of human paleopathology. Cambridge University Press: Cambridge, UK; 118-141.

Baker BJ. (1999) Early manifestations of tuberculosis in the skeleton. In Tuberculosis: past and present, Pálfi Gy, Dutour O, Deák J, Hutás I. (eds) TB Foundation: Szeged, Hungary \& Golden Book Publisher: Budapest, Hungary; 301-307.

Baker O, Lee OY-C, Wu HHT, Besra GS, Minnikin DE, Llewellyn G, Williams CM, Maixner F, O'Sullivan N, Zink A, (...), Dutour O. (2015) Human tuberculosis predates domestication in ancient Syria. Tuberculosis. 95(Suppl.1): S4-S19. DOI: 10.1016/j.tube.2015.02.001.

Bakuła Z, Kościuch J, Safianowska A, Proboszcz M, Bielecki J, van Ingen J, Krenke R, Jagielski T. (2018) Clinical, radiological and molecular features of Mycobacterium kansasii pulmonary disease. Resp Med 139: 91-100. DOI: 10.1016/j.rmed.2018.05.007.

Bañuls A-L, Sanou A, Nguyen TVA \& Godreuil S. (2015) Mycobacterium tuberculosis: ecology and evolution of human bacterium. J Med Microbiol. 64(11): 1261-1269. DOI: 10.1099/jmm.0.000171.

Barberis I, Bragazzi NL , Galluzzo L, Martini M (2017) The history of tuberculosis: from the first historical records to the isolation of Koch's bacillus J Prev Med Hyg. 58: E9-E12.

Batt SM, Minnikin DE, Besra GS. (2020) The thick waxy coat of mycobacteria, a protective layer against antibiotics and the host's immune system. Biochem J. 477(10): 1983-2006. DOI: 10.1042/BCJ20200194.

Bello S, Signoli M, Maczel M, Dutour O. (1999) Evolution of mortality due to tuberculosis in France (18-20 th centuries). Pálfi Gy, Dutour O, Deák J, Hutás I. (eds) Tuberculosis past and present. TB Foundation: Szeged, Hungary \& Golden Book Publisher: Budapest, Hungary. 95-104.

Bermudez LE, Sangari FJ. (2001) Cellular and molecular mechanisms of internalization of mycobacteria by host cells. Microbes Infect. 3(1): 37-42. DOI: 10.1016/S12864579(00)01355-1. 
Bhamidi S, Scherman MS, Jones V, Crick DC, Belisle JT, Brennan PJ, McNeil MR. (2011) Detailed structural and quantitative analysis reveals the spatial organization of the cell walls of in vivo grown Mycobacterium leprae and in vitro grown Mycobacterium tuberculosis. $\mathrm{J}$ Biol Chem. 286(26): 23168-23177. DOI: 10.1074/jbc.M110.210534.

Blanc L, Gilleron M, Prandi J, Song O, Jang M-S, Gicquel B, Drocourt D, Neyrolles O, Brodin P, Tiraby G, (...), Nigou J. (2017) Mycobacterium tuberculosis inhibits human innate immune responses via the production of TLR2 antagonist glycolipids. PNAS. 114(42): 11205-11210. DOI: 10.1073/pnas.1707840114.

Blázquez J, Espinosa de Los Monteros LE, Samper S, Martín C, Guerrero A, Cobo J, Van Embden J, Baquero F \& Gómez-Mampaso E. (1997) Genetic characterization of multidrugresistant Mycobacterium bovis strains from a hospital outbreak involving Human Immunodeficiency Virus-positive patients. J Clin Microbiol. 35(6): 1390-1393.

Blevins KE, Crane AE, Lum C, Furuta K, Fox K, Stone AC. (2020) Evolutionary history of Mycobacterium leprae in the Pacific Islands. Phil Trans R Soc B. 375: 20190582. DOI: 10.1098/rstb.2019.0582.

Borah K, Kearney J-L, Banerjee R, Vats P, Wu H, Dahale S, Kasibhatla SM, Joshi R, Bonde B, Ojo O, (...), McFadden J. (2020) GSMN-ML- a genome scale metabolic network reconstruction of the obligate human pathogen Mycobacterium leprae. PLoS Negl Trop Dis 14(7): e0007871. DOI: 10.1371/journal.pntd.0007871.

Boritsch EC, Brosch R. (2018) Evolution of Mycobacterium tuberculosis: New Insights into Pathogenicity and Drug Resistance. In: Jacobs WR, McShane H, Mizrahi V, Orme IM. (eds) Tuberculosis and the Tubercle Bacillus, 2nd ed. American Society for Microbiology, Washington, DC. 495-515. DOI: 10.1128/microbiolspec.TBTB2-0020-2016.

Borowska-Strugińska B, Druszczyńska M, Lorkiewicz W, Szewczyk R, Żądzińska E. (2014) Mycolic acids as markers of osseous tuberculosis in the Neolithic skeleton from Kujawy region (central Poland). Anthropological Review. 77(2): 137-149. DOI: 10.2478/anre-20140012.

Bos KI, Harkins KM, Herbig A, Coscolla M, Weber N, Comas I, Forrest SA, Bryant JM, Harris SR, Schuenemann VJ, (...), Krause J. (2014) Pre-Columbian mycobacterial genomes reveal seals as a source of New World human tuberculosis. Nature. 514(7523): 494-497. DOI: $10.1038 /$ nature13591. 
Bouwman, A.S.; Kennedy, S.L.; Müller, R.; Stephens, R.H.; Holst, M.; Caffell, A.C.; Roberts, C.A.; Brown, T.A. (2012) Genotype of a historic strain of Mycobacterium tuberculosis. PNAS, 109, 18511-18516.

Bouzid F, Brégeon F, Poncin I, Weber P, Drancourt M and Canaan S. (2017) Mycobacterium canettii infection of adipose tissues. Front Cell Infect Microbiol. 7:189. DOI: 10.3389/fcimb.2017.00189.

Brites D \& Gagneux S. (2017) The Nature and Evolution of Genomic Diversity in the Mycobacterium tuberculosis Complex. In: Gagneux S. (eds) Strain Variation in the Mycobacterium tuberculosis Complex: Its Role in Biology, Epidemiology and Control. Advances in Experimental Medicine and Biology, vol 1019. Springer, Cham. DOI: 10.1007/978-3-319-64371-7_1.

Brites D, Loiseau C, Menardo F, Borrell S, Boniotti MB, Warren R, Dippenaar A, Parsons SDC, Beisel C, Behr MA, Fyfe JA, Coscolla M and Gagneux S. (2018) A new phylogenetic framework for the animal-adapted Mycobacterium tuberculosis Complex. Front Microbiol. 9:2820. DOI: 10.3389/fmicb.2018.02820.

Brosch R, Gordon SV, Marmiesse M, Brodin P, Buchrieser C, Eiglmeier K, Garnier T, Gutierrez C, Hewinson G, Kremer K, Parsons LM, Pym AS, Samper S, van Soolingen D, Cole ST (2002) A new evolutionary scenario for the Mycobacterium tuberculosis complex. PNAS. 99(6): 3684-3689. DOI: 10.1073/pnas.052548299.

Brown L. (1941) The story of clinical pulmonary tuberculosis. Baltimore, MD: Williams \& Wilkins Company.

Busatto C, Vianna JS, da Silva LV Jr, Ramis IB, da Silva PEA (2019) Mycobacterium avium: an overview. 114: 127-134. DOI: 10.1016/j.tube.2018.12.004.

Busch M, Herzmann C, Kallert S, Zimmermann A, Höfer C, Mayer D, Zenk SF, Muche R, Lange C, Bloom BR, Modlin RL (...) Stenger S. (2016) Lipoarabinomannan-responsive polycytotoxic T cells are associated with protection in human tuberculosis. Am J Respir Crit Care Med. 194(3): 345-355. DOI: 10.1164/rccm.201509-1746OC.

Byrdwell WC. (2001) Atmospheric Pressure Chemical Ionization Mass Spectrometry for Analysis of Lipids. Lipids. 36(4): 327-346. DOI: 10.1007/s11745-001-0725-5. 
Cambier C, Takaki K, Larson R, Hernandez RE, Tobin DM, Urdahl KB, Cosma CL, Ramakrishnan L. (2014) Mycobacteria manipulate macrophage recruitment through coordinated use of membrane lipids. Nature 505: 218-222. DOI: 10.1038/nature12799.

Castets M, Boisvert H, Grumbach F, Brunel M \& Rist N. (1968) Tuberculosis bacilli of the African type: preliminary note. Rev. Tuberc. Pneumol. 32: 179-184.

Cavanagh R, Begon M, Bennett M, Ergon T, Graham IM, de Haas PEW, Hart CA, Koedam M, Kremer K, Lambin X, (...), van Soolingen D. (2002) Mycobacterium microti infection (Vole tuberculosis) in wild rodent populations. J Clin Microbio. 40(9): 3281-3285. DOI: 10.1128/JCM.40.9.3281-3285.2002.

Cave AJE. (1939) The evidence for the incidence of tuberculosis in ancient Egypt. Br J Tuberc. 33: 142-152.

Chan JZ-M, Sergeant MJ, Lee OY-C, Minnikin DE, Besra GS, Pap I, Spigelman M, Donoghue HD, Pallen MJ. (2013) Metagenomic analysis of tuberculosis in a mummy. N Engl J Med. 369: 289-290. DOI: 10.1056/NEJMc1302295.

Chancellor A, Tocheva AS, Cave-Ayland C, Tezera L, White A, Al Dulayymi JR, Bridgeman JS, Tews I, Wilson S, Lissin NM, (...), Mansour S. (2017) CD1b-restricted GEM $\mathrm{T}$ cell responses are modulated by Mycobacterium tuberculosis mycolic acid meromycolate chains. PNAS. 114(51): E10956-E10964. DOI: 10.1073/pnas.1708252114.

Chang H-Y, Tsai W-C, Lee T-F, Sheng W-H. (2020) Mycobacterium gordonae infection in immunocompromised and immunocompetent hosts: A series of seven cases and literature review. J Formos Med Assoc. S0929-6646(20)30289-8. DOI: 10.1016/j.jfma.2020.06.029.

Chen Y, Jiang J, Jiang H, Chen J, Wang X, Liu W, Chen Z, Shi Y, Zhang W, Wang H. (2017) Mycobacterium gordonae in patient with facial ulcers, nosebleeds, and positive TSPOT.TB Test, China. Emerg Infect Dis. 23(7): 1204-1206. DOI: 10.3201/eid2307.162033.

Chisholm RH, Trauer JM, Curnoe D, Tanaka MM. (2016) Controlled fire use in early humans might have triggered the evolutionary emergence of tuberculosis. PNAS. 113(32): 9051-9056. DOI: 10.1073/pnas.1603224113.

Clarke C, Patterson SJ, Drewe JA, van Helden PD, Miller MA \& Parsons SDC. (2016) Development and evaluation of a diagnostic cytokine-release assay for Mycobacterium 
suricattae infection in meerkats (Suricata suricatta). BMC Vet Res. 13: 2. DOI: 10.1186/s12917-016-0927-x.

CLSI, 2018. Interpretive criteria for identification of bacteria and fungi by targeted DNA sequencing, 2. Clinical and Laboratory Standards Institute, Wayne, PA.

Cole S, Brosch R, Parkhill J, Garnier T, Churcher C, Harris D, Gordon SV, Eiglmeier K, Gas S, Barry III Ce, (...), Barell BG. (1998) Deciphering the biology of Mycobacterium tuberculosis from the complete genome sequence. Nature. 393: 537-544. DOI: $10.1038 / 31159$.

Coll F, McNerney R, Guerra-Assunção J, Glynn JR, Perdigaõ J, Viveiros M, Portugal I, Pain A, Martin N, Clark TG. (2014) A robust SNP barcode for typing Mycobacterium tuberculosis complex strains. Nat Commun. 5: 4812. DOI:10.1038/ncomms5812.

Comas I, Coscolla M, Luo T, Borell S, Holt KE, Kato-Maeda M, Parkhill J, Malla B, Berg S, Thwaites G, (...), Gagneux S. (2013) Out-of-Africa migration and Neolithic coexpansion of Mycobacterium tuberculosis with modern humans. Nat Genet. 45: 1176-1182. DOI: 10.1038/ng.2744.

Coscolla M, Lewin A, Metzger S, Maetz-Rennsing K, Calvignac-Spencer S, Nitsche A, Dabrowski PW, Radonic A, Niemann S, Parkhill J., (...), Gagneux S \& Leendertz FH. (2013) Novel Mycobacterium tuberculosis Complex isolate from a Wild Chimpanzee. Emerg Infect Dis. 19(6): 969-976. DOI: 10.3201/eid1906.121012.

Cousins DV, Peet RL, Gaynor WT, Williams SN, Gow BL. (1994) Tuberculosis in imported hyrax (Procavia capensis) caused by an unusual variant belonging to the Mycobacterium tuberculosis complex. Vet Microbiol. 42:135-45.

Crane AM, Hua HU, Coggin AD, Gugiu BG, Lam BL, Bhattacharya SK. (2012) Mass spectrometric analyses of phosphatidylcholines in alkali-exposed corneal tissue. Invest Ophthalmol Vis Sci. 53(11): 7122-7130. DOI: 10.1167/iovs.12-10448.

Cseplák Gy, Pap I, Szikossy I. (2015) A váci múmiákról - Antropo-medicinális tanulmányok 52 váci múmia vizsgálatáról egy bőrgyógyász fényképes jegyzeteivel. Budapest: Semmelweis Kiadó és Multimédia Stúdió Kft. 
Cvetnic Z, Katalinic-Jankovis V, Sostaric B, Spicic S, Obrovac M, Marjanovic S, Benic M, Kirin BK, Vickovic I. (2007) Mycobacterium caprae in cattle and humans in Croatia. Int J Tuberc Lung Dis. 11(6) 652-658.

Daffé M, Lanéelle MA. (1988) Distribution of phthiocerol diester, phenolic mycosides and related compounds in mycobacteria. J Gen Microbiol. 134(7): 2049-2055. DOI: 10.1099/00221287-134-7-2049.

Daffé M, Marrakchi H. (2019) Unraveling the structure of the mycobacterial envelope. Microbiol Spectr. 7(4): 1087-1094. DOI: 10.1128/microbiolspec.GPP3-0027-2018.

Daley CL, Griffith DE. (2010) Pulmonary non-tuberculous mycobacterial infections. Int J Tuberc Lung Dis. 14(6): 665-671.

Dang NA, Kuijper S, Walters E, Claassens M, van Soolingen D, Vivi-Truyols G, Janssen HG, Kolk AHJ. (2013) Validation of Biomarkers for Distinguishing Mycobacterium tuberculosis from Non-Tuberculous Mycobacteria Using Gas Chromatography-Mass Spectrometry and Chemometrics. PLoS ONE. 8(10): e76263. DOI: 10.1371/journal.pone.0076263.

Daniel TM. (2006) The history of tuberculosis. Respiratory Medicine. 100: 1862-1870.

Daniel TM. (2004) Theophile Hyacinthe Laennec and the founding of pulmonary medicine. Int J Tuberc Lung Dis. 8(5):517-518.

Daniel VS, Daniel TM. (1999) Old testament biblical references to tuberculosis. Clin Infect Dis. 29(6): 1557-1558. DOI: 10.1086/313562.

Dawson KL, Bell A, Kawakami RP, Coley K, Yates G \& Collins DM. (2012) Transmission of Mycobacterium orygis (M. tuberculosis Complex Species) from a Tuberculosis Patient to a Dairy Cow in New Zealand. J Clin Microbiol. 50(9): 3136-3138. DOI: 10.1128/JCM.01652-12.

de Jong BC, Adetifa I, Walther B, Hill PC, Antonio M, Ota M \& Adegbola RA. (2010b) Differences between TB cases infected with M. africanum, West-African type 2, relative to Euro-American M. tuberculosis- an update. FEMS Immunol Med Microbiol. 58(1): 102105. DOI: 10.1111/j.1574-695X.2009.00628.x. 
de Jong BC, Antonio M, Gagneux S. (2010a) Mycobacterium africanum - Review of an important cause of human tuberculosis in West Africa. PLoS Negl Trop Dis. 4(9): e744. DOI:10.1371/journal.pntd.0000744.

de la Rua-Domenech R. (2006) Human Mycobacterium bovis infection in the United Kingdom: Incidence, risks, control measures and review of the zoonotic aspects of bovine tuberculosis. Tuberculosis. 86(2): 68-76. DOI: 10.1016/j.tube.2005.05.002.

Dippenaar A, Parsons, SDC, Sampson SL, van der Merwe SG, Drewe JA, Abdallah AM, Siame KK, van Pittius NCG, van Helden PD, Pain A, Warren RM. (2015) Whole genome sequence analysis of Mycobacterium suricattae. Tuberculosis. 95(6): 682-688. 10.1016/j.tube.2015.10.001.

Donoghue HD, Taylor MG, Stewart GR, Lee OY-C, Wu HHT, Besra GS, Minnikin DE. (2017) Positive diagnosis of ancient leprosy and tuberculosis using ancient DNA and lipid biomarkers. Diversity. 9(4): 46. DOI: 10.3390/d9040046.

Donoghue, HD, Spigelman M, Zias J, Gernaey-Child AM, Minnikin DE. (1998) Mycobacterium tuberculosis complex DNA in calcified pleura from remains 1400 years old. Lett Appl Microbiol. 27: 265-269

Dorn-In S, Körner T, Büttner M, Hafner-Marx A, Müller M, Heurich M, Varadharajan A, Blum H, Gareis M, Schwaiger K. (2020) Shedding of Mycobacterium caprae by wild red deer (Cervus elaphus) in the Bavarian alpine regions, Germany. Transbound Emerg Dis. 67(1): 308-317. DOI: 10.1111/tbed.13353.

Draper P, Payne SN, Dobson G, Minnikin DE. (1983) Isolation of a characteristic phthiocerol dimycocerosate from Mycobacterium leprae. J Gen Microbiol. 129(3): 859-863. https://doi.org/10.1099/00221287-129-3-859.

Duffin J. (1998) To see with a better eye. A life of R.T.H. Laennec. Princeton, NJ: Princeton University Press.

Dulberger CL, Rubin EJ, Boutte CC. (2020) The mycobacterial cell envelope - a moving target. Nat Rev Microbiol. 18: 47-59. DOI: 10.1038/s41579-019-0273-7.

EMMI, State Secretariat for Healthcare (2018) Egészségügyi szakmai irányelv - A tuberkulózis prevenciójáról, diagnosztikájáról, terápiájáról és gondozásáról. 
https://www.hbcs.hu/uploads/jogszabaly/2838/fajlok/EMMI_szakmai_iranyelve_tuberkulo zis.pdf; 2014 (accessed 01 August 2020).

Erber S, Weidlich S, Tschaikowsky T, Rothe K, Schmid RM, Schneider J, Spinner CD (2020) Successful bedaquiline-containing antimycobacterial treatment in posttraumatic skin and soft-tissue infection by Mycobacterium fortuitum complex: a case report. BMC Infectious Diseases. 20: 365. DOI: 10.1186/s12879-020-05075-7.

Ernst WA, Maher J, Cho S, Niazi Kr, Chatterjee D, Moody DB, Besra GS, Watanabe Y, Jensen PE, Porcelli SA, (...), Modlin RL. (1998) Molecular Interaction of CD1b with Lipoglycan Antigens. Immunity. 8: 331-340.

Esteves S, Catarino I, Lopes D, Sousa C. (2017) Spinal tuberculosis: rethinking an old disease. Eur Spine J. 6(1): 358. DOI: 10.4172/2165-7939.1000358.

Firdessa R, Berg S, Hailu E, Schelling E, Gumi B, Erenso G, Gadisa E, Kiros T, Habtamu M, Hussein J, (...), Aseffa A. (2013) Mycobacterial Lineages Causing Pulmonary and Extrapulmonary Tuberculosis, Ethiopia. Emerg Infect Dis. 19(3): 460-463. DOI: 10.3201/eid1903.120256.

Fletcher HA, Donoghue HD, Holton J, Pap I, Spigelman M. (2003) Widespread occurrence of Mycobacterium tuberculosis DNA from 18th-19th century Hungarians. Am J Phys Anthropol. 120(2): 144-52. DOI: 10.1002/ajpa.10114.

Flynn JL, Chan J. (2001) Tuberculosis: latency and reactivation. Infect Immun. 69(7): 41954201. DOI: 10.1128/IAI.69.7.4195-4201.2001.

Fogel N. (2014) Tuberculosis: A disease without boundaries. Tuberculosis. 95(5): 527-531. DOI: 10.1016/j.tube.2015.05.017.

Gagneux S, DeRiemer K, Van T, Kato-Maeda M, de Jong BC, Narayanan S, Nicol M, Niemann S, Kremer K, Gutierrez MC, (...), Small PM (2006) Variable host-pathogen compatibility in Mycobacterium tuberculosis. PNAS. 103(8): 2869-2873. DOI: 10.1073/pnas.0511240103.

Gagneux S. (2018) Ecology and evolution of Mycobacterium tuberculosis. Nat Rev Microbiol. 16: 202-213. DOI: 10.1038/nrmicro.2018.8.

Gagneux S. (2012) Host-pathogen coevolution in human tuberculosis. Phil Trans R Soc B. 367: 850-859. DOI:10.1098/rstb.2011.0316. 
Garnier T, Eiglmeier K, Camus J-C, Medina N, Mansoor H, Pryor M, Duthoy S, Grondin S, Lacroix C, Monsempe C, (...), Hewinson RG. (2003) The complete genome sequence of Mycobacterium bovis. PNAS. 100(13): 7877-7882. DOI:10.1073/pnas.1130426100.

Gernaey AM, Minnikin DE, Copley MS, Power JJ, Ahmed AMS, Dixon RA, Roberts CA, Robertson JD, Nolan J, Chamberlain A. (1998) Detecting ancient tuberculosis. Internet Archaeol. http://intarch.ac.uk/journal/issue5/gernaey_index.html.

Gernaey AM, Minnikin,DE, Copley MS, Dixon RA,t Middleton JC, Roberts CA. (2001) Mycolic acids and ancient DNA confirm an osteological diagnosis of tuberculosis. Tuberculosis. 81(4): 259-265. DOI: 10.1054/tube.2001.0295.

Getahun H, Matteelli A, Chaisson RE, Raviglione M. (2015) Latent Mycobacterium tuberculosis Infection. N Engl J Med. 372: 2127-2135. DOI: 10.1056/NEJMra1405427.

Gilleron M, Stenger S, Mazorra Z, Wittke F, Mariotti S, Böhmer G, Prandi J, Mori L, Puzo G, Libero GD. Diacylated Sulfoglycolipids Are Novel Mycobacterial Antigens Stimulating CD1-restricted T Cells during Infection with Mycobacterium tuberculosis. J Exp Med. 199(5): 649-659. DOI: https://doi.org/10.1084/jem.20031097.

Glaziou P, Floyd, K, Raviglione M (2018) Trends in tuberculosis in the UK. Thorax 73: 702703. DOI: 10.1136/thoraxjnl-2018-211537.

Godreuil S, Tazi L, Bañuls A-L. (2006) Pulmonary Tuberculosis and Mycobacterium tuberculosis: Modern Molecular Epidemiology and Perspectives. In: Tibayrenc M. (eds) Encyclopedia of Infectious Diseases: Modern Methodologies.

Golden MP, Vikram HR. (2005) Extrapulmonary tuberculosis: an overview. Am Fam Physician. 72(9): 1761-1768.

Gordon SV, Brosch R, Billault A, Garnier T, Eiglmeier K, Cole ST. (1999) Identification of variable regions in the genomes of tubercle bacilli using bacterial artificial chromosome arrays. Mol Microbiol. 32(3): 643-655. DOI:10.1046/j.1365-2958.1999.01383.x.

Gutierrez MC, Brisse S, Brosch R, Fabre M, Omaïs B, Marmiesse M, Supply P, Vincent V. (2005) Ancient origin and gene mosaicism of the progenitor of Mycobacterium tuberculosis. PloS Pathog. 1(1): e5. DOI: 10.1371/journal.ppat.0010005. 
Han X, Yang K, Gross RW. (2012) Multi-dimensional mass spectrometry-based shotgun lipidomics and novel strategies for lipidomic analyses. Mass Spectrom Rev. 31(1): 134-178. DOI: $10.1002 /$ mas.20342.

Hartmann S, Minnikin DE. (1992) Mycobacterial phenolic glycolipids. In: Tyman JHP, (ed). Surfactants in lipid chemistry: recent synthetic, physical and biodegradative studies. Cambridge: Royal Society of Chemistry. 135-158.

Hershkovitz I, Greenwald CM, Latimer B, Jellema LM, Wish-Baratz S, Eshed V, Dutour O, Rotschild BM. (2002) Serpens endocrania symmetrica (SES): a new term and a possible clue for identifying intrathoracic disease in skeletal populations. Am J Phys Anthropol. 118(3): 201-216. DOI: 10.1002/ajpa.10077.

Hershkovitz I, Donoghue HD, Minnikin DE, Besra GS, Lee OY-C, Gernaey, AM, Galili E, Eshed V, Greenblatt CL, Lemma E, Bar-Gal GK, Spigelman M. (2008) Detection and molecular characterization of 9000-year-old Mycobacterium tuberculosis from a Neolithic settlement in the Eastern Mediterranean. PLOS ONE. 3(10): e3426. DOI: 10.1371/journal.pone.0003426.

Horai S, Yamauchi N, Naraoka H. (2019) Simultaneous total analysis of core and polar membrane lipids in archaea by high-performance liquid chromatography/high-resolution mass spectrometry coupled with heated electrospray ionization. Rapid Commun Mass Spectrom. 33(20): 1571-1577. DOI: 10.1002/rcm.8506.

Huang H-L, Lu P-L, Lee C-H, Chong I-W. (2020) Treatment of pulmonary disease caused by Mycobacterium kansasii. Journal of the Formosan Medical Association. 119: S51-S57. DOI: $10.1016 /$ j.jfma.2020.05.018.

Hunter RL, Armitige L, Jagannath C, Actor JF. (2006) TB Research at UT-Houston - A review of cord factor: new approaches to drugs, vaccines and the pathogenesis of tuberculosis. Tuberculosis. 89(Suppl 1): S18-S25. DOI: 10.1016/S1472-9792(09)70007-1.

Ishikawa E, Ishikawa T, Morita YS, Toyonaga K, Yamada H, Takeuchi O, Kinoshita T, Akira S, Yoshikai Y, Yamasaki S. (2009) Direct recognition of the mycobacterial glycolipid, trehalose dimycolate, by C-type lectin Mincle. J Exp Med. 206(13): 2879-2888. DOI: https://doi.org/10.1084/jem.20091750.

Jackson M. (2014) The Mycobacterial Cell Envelope-Lipids. Cold Spring Harb Perspect Med. 4: a021105. DOI: 10.1101/cshperspect.a021105. 
Jankute M, Nataraj V, Lee OY-C, Wo HHT, Ridell M, Garton NJ, Barer MR, Minnikin DE, Bhatt A, Besra GF. (2017) The role of hydrophobicity in tuberculosis evolution and pathogenicity. Sci Rep .7: 1315 DOI: 10.1038/s41598-017-01501-0.

Johnston JC, Chiang L, Elwood K. (2017) Mycobacterium kansasii. Microbiol Spectr. 5(1). DOI:10.1128/microbiolspec.TNMI7-0011-2016.

Kajdocsi Lovász G. (2015) A török hódoltság kori idegen etnikumok összehasonlító embertani vizsgálata. Ph.D. Thesis, University of Szeged, Faculty of Science and Informatics, Szeged, Hungary.

Kaur D, Berg S, Dinadayala P, Gicquel B, Chatterjee D, McNeil MR, Vissa VD, Crick DC, Jackson M, Brennan PJ. (2006) Biosynthesis of mycobacterial lipoarabinomannan: Role of a branching mannosyltransferase. PNAS. 103(37): 13664-13669; DOI: 10.1073/pnas.0603049103.

Kay GL, Sergeant MJ, Zhou Z, Chan JZ-M, Millard A, Quick J, Szikossy I, Pap I, Spigelman M, Loman NJ, (...), Pallen MJ. (2015) Eighteenth-century genomes show that mixed infections were common at time of peak tuberculosis in Europe. Nat Commun. 6: 6717. DOI: $10.1038 /$ ncomms 7717 .

Kiers A, Klarenbeek A, Mendelts B, Van Soolingen D, Koëter G. (2008) Transmission of Mycobacterium pinnipedii to humans in a zoo with marine mammals. Int J Tuberc Lung Dis. 12(12):1469-1473.

Koeck JL, Fabre M, Simon F, Daffe M, Garnotel E, Matan AB, Gerome P, Bernatas JJ, Buisson Y, Pourcel C (2011) Clinical characteristics of the smooth tubercle bacilli 'Mycobacterium canettii' infection suggest the existence of an environmental reservoir. Clin Microbiol Infect. 17(7): 1013-1019. 10.1111/j.1469-0691.2010.03347.x.

Koh W-J, Moon SM, Kim S-Y, Woo M-A, Kim S, Jhun BW, Park HY, Jeon K, Huh HJ, Ki C-S, (...), Kwon OJ. (2017) Outcomes of Mycobacterium avium complex lungdisease based on clinical phenotype. Eur Respir J. 50: 1602503. DOI: 10.1183/13993003.02503-2016.

Koivusalo M, Haimi P, Heikinheimo L, Kostiainen R, Somerharju P. (2001) Quantitative determination of phospholipid compositions by ESI-MS: effects of acyl chain length, unsaturation, and lipid concentration on instrument response. J Lipid Res. 42(4): 663-672. 
Kustár Á, Pap I, Végvári Zs, Kristóf LA, Pálfi Gy, Karlinger K, Kovács KB, Szikossy I. (2011) Using of 3D virtual reconstruction for pathological investigation and facial reconstruction of an 18th century mummified nun from Hungary. Yearbook of Mummy Studies. 1:83-93.

Laval F, Lanéelle M-A, Déon C, Monsarrat B, Daffé M. (2001) Accurate molecular mass determination of mycolic acids by MALDI-TOF mass spectrometry. Anal Chem. 73(18): 4537-4544. DOI: 10.1021/ac0105181.

Lee OY-C, Wu HHT, Donoghue HD, Spigelman M, Greenblatt CL, Bull ID, Rothschild BM, Martin LD, Minnikin DE, Besra GS. (2012) Mycobacterium tuberculosis complex lipid virulence factors preserved in the 17,000-year-old skeleton of an extinct bison, Bison antiquus. PLoS ONE, 7: e41923.

Lehmann J, Cheng T-Y, Aggarwal A, Park AS, Zeiler E, Raju RM, Akopian T, Kandor O, Bach, Sacchettini JC, (...), Sieber SA. (2018) An antibacterial $\beta$-lactone kills Mycobacterium tuberculosis by infiltrating mycolic acid biosynthesis. Angew Chem Int Ed Engl. 57(1): 348-353. DOI: 10.1002/ange.201709365.

Loddenkemper R, Murray JF, Gradmann C, Hopewell PC, Kato-Maeda M. (2018) History of tuberculosis. In: Migliori GB, Bothamley G, Duarte, R, Rendon A (eds) Tuberculosis. Charlesworth Press, Wakefield, UK. 8-27.

LPSN: https://lpsn.dsmz.de/ Last download: 23.10.2020.

Luna LH, Aranda CM, Santos AL, Donoghue HD, Lee OY-C, Wu HHT, Besra GS, Minnikin DE, Llewellyn G, Williams CM, Ratto N. (2020) Oldest evidence of tuberculosis in Argentina: A multidisciplinary investigation in an adult male skeleton from Saujil, Tinogasta, Catamarca $(905-1030 \quad$ CE). Tuberculosis. 125: $101995 . \quad$ DOI: 10.1016/j.tube.2020.101995.

Macedo R, Isidro J, Gomes MC, Botelho A, Albuquerque, Sogorb A, Bernardino R, Fernandes TL, Mourato T, Durval M, Gomes JP. (2020) Animal-to-human transmission of Mycobacterium pinnipedii. Eur Respir J. 56(4); in press. DOI: 10.1183/13993003.003712020

Maczel M. (2003) „On the traces of tuberculosis” Diagnostic criteria of tuberculosis affection of the human skeleton and their application in Hungarian and French anthropological series. Ph.D. Thesis, University of La Méditerranée - Aix Marseille II 
Faculty of Medicine, Marseille, France \& University of Szeged, Faculty of Science, Szeged, Hungary.

Malaviya AN, Kotwal PP. (2003) Arthritis associated with tuberculosis. Best Pract Res Clin Rheumatol. 17(2): 319-343. DOI: 10.1016/S1521-6942(02)00126-2.

Mandal S, Bradshaw L, Anderson LF, Brown T, Evans JT, Drobniewski F, Smith G, Magee JG, Barrett A, Blatchford O, (...) Hawkey P \& Abubakar I. (2011) Investigating Transmission of Mycobacterium bovis in the United Kingdom in 2005 to 2008. J Clin Microbiol. 49(5): 1943-1950. DOI: 10.1128/JCM.02299-10.

Marcos LA, Spitzer ED, Mahapatra R, Ma Y, Halse TA, Shea J, Isabelle M, Lapierre P, Escuyer VE. (2017) Mycobacterium orygis Lymphadenitis in New York, USA. Emerg Infect Dis. 23(10): 1749-1751. DOI: 10.3201/eid2310.170490.

Marcsik A, Molnár E, Ösz B, Donoghue HD, Zink A, Pálfi Gy. (2009) Adatok a lepra, tuberculosis és syphilis magyarországi paleopatológiájához. Folia Anthropologica 8: 5-34.

Marcsik A, Szentgyörgyi R, Gyetvai A, Finnegan M, Pálfi Gy. (1999) Probable Pott's paraplegia from the 7th-8th century AD. In Tuberculosis: past and present, Pálfi Gy, Dutour O, Deák J, Hutás I. (eds). TB Foundation: Szeged, Hungary \& Golden Book Publisher: Budapest, Hungary, 331-336.

Mariotti V, Zuppello M, Pedrosi ME, Bettuzzi M, Brancaccio R, Peccenini E, Morigi MP, Belcastro MG. (2015) Skeletal evidence of tuberculosis in a modern identified human skeletal collection (Certosa cemetery, Bologna, Italy). Am J Phys Anthropol. 157(3): 389401. DOI: 10.1002/ajpa.22727.

Masson M, Bereczki Zs, Molnár E, Donoghue HD, Minnikin DE, Lee OY-C, Wu HHT, Besra GS, Bull ID, Pálfi Gy. (2015) 7000-year-old tuberculosis cases from Hungary Osteological and biomolecular evidence. Tuberculosis 95(Suppl. 1): S13-S17. DOI: 10.1016/j.tube.2015.02.007

Masson M, Molnár E, Donoghue HD, Besra GS, Minnikin DE, Wu HHT, Lee OY-C, Bull ID, Pálfi Gy. (2013) Osteological and biomolecular evidence of a 7000-year-old case of hypertrophic pulmonary osteopathy secondary to tuberculosis from Neolithic Hungary. PLoS ONE. 8(10): e78252. DOI: 10.1371/journal.phone.0078252. 
Matos V, Santos AL. (2006) On the trail of pulmonary tuberculosis based on rib lesions: results from the human identified skeletal collection from the Museu Bocage (Lisbon, Portugal). Am J Phys Anthropol .130(2): 190-200. DOI: 10.1002/ajpa.20309.

Mays S, Taylor GM, Legge AJ, Young DB, Turner-Walker G. (2001) Am. J. Paleopathological and biomolecular study of tuberculosis in a medieval skeletal collection from England. Am J Phys Anthropol. 114: 298-311.

Meir M, Grosfel T, Barkan D. (2017) Establishment and Validation of Galleria mellonella as a Novel Model Organism To Study Mycobacterium abscessus Infection, Pathogenesis, and Treatment. Antimicrob Agents Chemother. 62: e02539-17. DOI.. 10.1128/AAC.0253917.

Michel AL, Venter L, Espie IW \& Coetzee ML. (2003) Mycobacterium tuberculosis infection in eight species at the national zoological gardens of South Africa, 1991-2001. J Zoo Wildl Med. 34(4): 364-370. DOI: 10.1638/02-063.

Minnikin DE, Bolton RC, Hartmann S, Besra GS, Jenkins PA, Mallet AI, Wilkins E, Lawson AM, Ridell M. (1993) An integrated procedure for the direct detection of characteristic lipids in tuberculosis patients. Ann Soc Belg Med Trop. 73(Suppl. 1): 13-24.

Minnikin DE, Brennan PJ. (2020) Lipids of Clinically Significant Mycobacteria. In: Goldfine H. (eds) Health Consequences of Microbial Interactions with Hydrocarbons, Oils, and Lipids. Handbook of Hydrocarbon and Lipid Microbiology. Springer, Cham. DOI: 10.1007/978-3-319-72473-7_7-1

Minnikin DE, Dobson G, Goodfellow M, Magnusson M, Ridell M. (1985) Distribution of some mycobacterial waxes based on the phthiocerol family. J Gen Microbiol. 131(6): 13751381. DOI: 10.1099/00221287-131-6-1375.

Minnikin DE, Kremer L, Dover LG, Besra GS. (2002) The methyl-branched fortifications of Mycobacterium tuberculosis. Chem Biol.9:545-53.

Minnikin DE, Lee OY-C, Wu HHT, Besra GS, Donoghue HD (2012) Molecular biomarkers for ancient tuberculosis. In: Understanding Tuberculosis - Deciphering the Secret Life of the Bacilli. Eds. P-J. Cardona. InTech -Open Access Publisher. Rijeka, Croatia. 1-36 http://www.intechopen.com/books/understanding tuberculosis-deciphering-the-secret-lifeof-the-bacilli. 
Minnikin DE, Lee OY-C, Wu HHT, Besra GS, Donoghue HD. (2020) Recognising the broad array of approaches available for the diagnosis of ancient tuberculosis: Comment on 'Infectious diseases and Neolithic transformations' (Fuchs et al. 2019 The Holocene 29: 1545-1557). The Holocene. 1-3. DOI: 10.1177/0959683619895572

Minnikin DE, Lee OY-C, Wu HHT, Nataraj V, Donoghue HD, Ridell M, Watanabe M, Alderwick L, Bhatt A, Besra GS. (2015) Pathophysiological implications of cell envelope structure of Mycobacterium tuberculosis and related taxa. In: Ribon W (eds) Tuberculosis Expanding Knowledge. InTech - Open Access Publisher. 145-75. DOI: 10.5772/59585.

Minnikin, D.E. (1982) Lipids: complex lipids, their chemistry, biosynthesis and role. In: Ratledge C, Stanford J. (eds) The Biology of Mycobacteria. Academic Press, London, UK. 95-184.

Molnár E, Donoghue HD, Lee OY-C, Wu HHT, Besra GS, Minnikin DE, Bull ID, Llewellyn G, Williams CM, Spekker O, Pálfi Gy. (2015) Morphological and biomolecular evidence for tuberculosis in 8th century AD skeletons from Bélmegyer-Csömöki domb, Hungary. Tuberculosis 95(Suppl. 1): S35-S41. DOI: 10.1016/j.tube.2015.02.032.

Moody DB, Guy MR, Grant E, Cheng T-Y, Brenner MB, Besra GS, Porcelli SA (2000) Cd1b-Mediated T Cell Recognition of a Glycolipid Antigen Generated from Mycobacterial Lipid and Host Carbohydrate during Infection. J Exp Med. 192(7): 965-976. DOI: https://doi.org/10.1084/jem.192.7.965.

Mostowy S Inwald J, Gordon S, Martin C, Warren R, Kremer K, Cousins D \& Behr MA. (2005) Revisiting the Evolution of Mycobacterium bovis. J Bacteriol. 187(18): 6386-6395. DOI: 10.1128/JB.187.18.6386-6395.2005.

Mougari F, Guglielmetti L, Raskine L, Sermet-Gaudelus I, Vezirisa N, Cambau E. (2016) Infections caused by Mycobacterium abscessus: epidemiology, diagnostic tools and treatment. Expert review of anti-infective therapy. 14 (12): 1139-1154. DOI: $10.1080 / 14787210.2016 .1238304$.

Murray JF, Rieder HL, Finley-Croswhite A. (2016) The King's Evil and the Royal Touch: the medical history of scrofula. Int $\mathbf{J}$ Tuberc Lung Dis. 20(6): 713-6. DOI: 10.5588/ijtld.16.0229

Ngabonziza JCS, Loiseau C, Marceau M, Jouet A, Menardo F, Tzfadia O, Antoine R, Niyigena EB, Mulders W, Fissette K, (...), Supply P. (2020) A sister lineage of the 
Mycobacterium tuberculosis complex discovered in the African Great Lakes region. Nat Commun 11: 2917 DOI: 10.1038/s41467-020-16626-6.

Nichols DS, Davies NW. (2002) Improved detection of polyunsaturated fatty acids as phenacyl esters using liquid chromatography-ion trap mass spectrometry. J Microbiol Methods. 50(2): 103-113. DOI: 10.1016/S0167-7012(02)00030-1.

Niemann S, Kubica T, Bange FC, Adjei O, Browne EN, Chinbuah MA, Diel R, Gyapong J, Horstmann RD, Joloba ML, Meyer CG, Mugerwa RD, Okwera A, Osei I, Owusu-Darbo E, Schwander SK \& Rüsh-Gerdes S. (2004) The species Mycobacterium africanum in the light of new molecular markers. J Clin Microbiol. 42(9): 3958-3962. DOI: 10.1128/JCM.42.9.3958-3962.2004.

Niemann S, Richter E, Rüsch-Gerdes S. (2002) Biochemical and genetic evidence for the transfer of Mycobacterium tuberculosis subsp. caprae Aranaz et al. 1999 to the species Mycobacterium bovis Karlson and Lessel 1970 (approved lists 1980) as Mycobacterium bovis subsp. caprae comb. nov. Int J Syst Evol Microbiol 52(2): 433-436. DOI: 10.1099/ijs.0.01963-0.

Nouioui I, Carro L, García-López M, Meier-Kolthoff JP, Woyke T, Kyrpides NC, Pukall R, Klenk H-P, Goodfellow M, Göker M. (2018) Genome-based taxonomic classification of the phylum Actinobacteria. Front Microbiol 9: 2007. DOI: 10.3389/fmicb.2018.02007.

O'Garra A, Redford PS, McNab FW, Bloom CI, Wilkinson RJ, Berry MP. (2013) The immune response in tuberculosis. Annu Rev Immunol. 31:475-527. DOI: 10.1146/annurevimmunol-032712-095939.

Okamori S, Asakura T, Nishimura T, Tamizu E, Ishii M, Yoshida M, Fukano H, Hayashi Y, Fujita M, Hoshino Y, (...), Hasegawa N. (2018) Natural history of Mycobacterium fortuitum pulmonary infection presenting with migratory infiltrates: a case report with microbiological analysis. BMC Infect Dis 18:1 DOI: 10.1186/s12879-017-2892-9.

Orgeur M, Brosch R. (2018) Evolution of virulence in the Mycobacterium tuberculosis complex. Curr Opin Microbiol. 41:68-75. DOI: 10.1016/j.mib.2017.11.021.

Orłowska B, Augustynowicz-Kopeć E, Krajewska M, Zabost A, Welz M, Kaczor S, Anusz K. (2017) Mycobacterium caprae transmission to free-living grey wolves (Canis lupus) in the Bieszczady Mountains in Southern Poland. Eur J Wildl Res. 63: 21. DOI: 10.1007/s10344-017-1079-4. 
Orme IM, Basaraba RJ. (2014) The formation of the granuloma in tuberculosis infection. Semin Immunol. 26(6): 601-609. DOI: 10.1016/j.smim.2014.09.009.

Ortalo-Magne A, Lemassu A, Lanéelle M-A, Bardou F, Silve G, Gounon P, Marchal G, Dafféé M. (1996) Identification of the Surface-Exposed Lipids on the Cell Envelopes of Mycobacterium tuberculosis and Other Mycobacterial Species. Journal of bacteriology 178(2): 456-461.

Ortner DJ. (2003) Infectious diseases: tuberculosis and leprosy. In Identification of pathological conditions in human skeletal remains, Ortner DJ (ed.). Academic Press, San Diego, CA, USA; 227-271.

Osman AD, Bouzid F, Canaan S \& Drancourt M. (2016) Smooth Tubercle Bacilli: Neglected Opportunistic Tropical Pathogens. Front Public Health. 3:283. DOI: 10.3389/fpubh.2015.00283.

Osmani M, Sotello D, Alvarez S, Odell JA, Thomas M. (2017) Mycobacterium abscessus infections in lung transplant recipients: 15-year experience from a single institution. Transpl Infect Dis. 20: e12835. DOI: 10.1111/tid.12835.

Pai M, Behr MA, Dowdy D, Dheda K, Divangahi M, Boehme CC, Ginsberg A, Swaminathan S, Spigelman M, Getahun H, Menzies D, Raviglione M. (2016) Tuberculosis. Nat Rev Dis Primers. 2: 16076. DOI: 10.1038/nrdp.2016.76.

Paja L, Coqueugniot H, Dutour O, Willmon R, Farkas GyL, Palkó A, Pálfi Gy. (2015) Knee ankyloses associated with tuberculosis from the Medieval Hungary - Differential diagnosis based on medical imaging techniques. International Journal of Osteoarchaeology 25(3): 352360. DOI: 10.1002/oa.2284.

Pálfi Gy, Maixner F, Maczel M, Molnár E, Pósa A, Kristóf LA, Marcsik A, Balázs J, Masson M, Paja L, (...), Dutour O. (2015) Unusual spinal tuberculosis in an Avar Age skeleton (Csongrád-Felgyő, Ürmös-tanya, Hungary): A morphological and biomolecular study. Tuberculosis. 95(Suppl1): S29-S34. DOI: 10.1016/j.tube.2015.02.033.

Pálfi Gy, Bereczki Zs, Ortner DJ, Dutour O (2012) Juvenile cases of skeletal tuberculosis from the Terry Anatomical Collection (Smithsonian Institution, Washington, D.C., USA). Acta Biologica Szegediensis. 56(1):1-12. 
Pálfi Gy, Csernus Z. (1990) Arthrite infectieuse ankylosante dans une série du VIIIe siècle en Hongrie. Paléobios. 6: 37-41.

Pálfi Gy, Dutour O, Perrin P, Sola C, Zink A. (2015) Tuberculosis in evolution. Tuberculosis 95(Suppl. 1): S1-S3. DOI: 10.1016/j.tube.2015.04.007.

Pálfi Gy, Marcsik A. (1999) Palaeoepidemiological data of tuberculosis in Hungary. In: Pálfí Gy, Dutour O, Deák J, Hutás I. (Eds) Tuberculosis: Past and Present. Golden Book - TB Foundation, Budapest - Szeged. 531-540.

Pálfi Gy, Molnár E. (2009) The Paleopathology of specific infectious diseases from Southeastern Hungary: a brief overview. Acta Biologica Szegediensis. 53(2): 111-116.

Panteix G, Gutierrez MC, Boschiroli ML, Rouviere M, Plaidy A, Pressac D, Porcheret H, Chyderiotos G, Ponsada M, Van Oortegem K, (...), Van de Perre P \& Godreuil S. (2010) Pulmonary tuberculosis due to Mycobacterium microti: a study of six recent cases in France. J Med Microbiol. 59(8): 984-989. DOI: 10.1099/jmm.0.019372-0.

Pap I, Józsa L, Repa I, Bajzik G, Lakhani SR, Donoghue HD, Spigelman M. (1999)18-19th century tuberculosis in naturally mummified individuals (Vác, Hungary). In: Pálfi Gy, Dutour O, Deák J, Hutás I, editors Tuberculosis: Past and Present. Budapest - Szeged, Hungary: Golden Book Publisher Ltd., Tuberculosis Foundation. 419-428.

Pap I, Pálfi Gy, Molnár E, Karlinger K, Kovács KB, Korom Cs, Schultz M, Schmidt-Schultz TH, Spigelman M, Donoghue HD, Kustár Á, Szikossy I. (2017) A tuberkulózis előfordulása egy XVIII. századi váci családban. Anthropol Közlem. 58:37-47. https://doi.org/10.20330/AnthropKozl.2017.58.37.

Parsons S, Smith SGD, Martins Q, Horsnell WGC, Gouse TA, Streichera EM, Warrena RM, van Heldena PD, van Pittius NCG. (2008) Pulmonary infection due to the dassie bacillus (Mycobacterium tuberculosis complex sp.) in a free-living dassie (rock hyrax-Procavia capensis) from South Africa. Tuberculosis. 88(1): 80-83. DOI: 10.1016/j.tube.2007.08.012.

Parsons SD, Drewe JA, Gey van Pittius NC, Warren RM \& van Helden PD. (2013) Novel cause of tuberculosis in meerkats, South Africa. Emerg Infect Dis. 19(12): 2004-2007. DOI: 10.3201/eid1912.130268.

Parsons SDC, Miller MA, van Helden PD. (2019) The Mycobacterium tuberculosis complex in Africa. In: Dibaba AB, Kriek NPJ, Thoen CO (eds) Tuberculosis in animals: An African 
Perspective. Springer Nature Switzerland AG, Cham, Switzerland. 73-87. DOI: 10.1007/978-3-030-18690-6_6.

Pérez de Val B, Sanz A, Soler M, Allepuz A, Michelet L, Boschiroli M, Vidal E. (2019) Mycobacterium microti Infection in Free-Ranging Wild Boar, Spain, 2017-2019. Emerg Infect Dis. 25(11): 2152-2154. DOI: 10.3201/eid2511.190746.

Philips JA, Ernst JD. (2012) Tuberculosis pathogenesis and immunity. Annu Rev Pathol. 7: 353-384. DOI: 10.1146/annurev-pathol-011811-132458.

Pieters J. (2001) Entry and survival of pathogenic mycobacteria in macrophages. Microbes Infect. 3(3): 249-255. DOI: 10.1016/s1286-4579(01)01376-4.

Portevin D, Sukumar S, Coscolla M, Shui G, Li B, Guan XL, Bendt AK, Young D, Gagneux S, Wenk MR. (2014) Lipidomics and genomics of Mycobacterium tuberculosis reveal lineage-specific trends in mycolic acid biosynthesis. Microbiologyopen. 3(6): 823-835. DOI: 10.1002/mbo3.193.

Procopie I, Popescu EL, Huplea V, Pleșea RM, Ghelase ȘM, Stoica GA, Mureșan RF, Onțică V, Pleșea IE, Anușca DN. (2017) Osteoraticular Tuberculosis-Brief Review of Clinical Morphological and Therapeutic Profiles. Curr Health Sci J. 43(3): 171-190. DOI: 10.12865/CHSJ.43.03.01.

Rafał S, Konrad K, Beata J-D, Magdalenad D. (2013) Rapid method for Mycobacterium tuberculosis identification using electrospray ionization tandem mass spectrometry analysis of mycolic acids. Diagn Microbiol Infect Dis. 76: 298-305. DOI: 10.1016/j.diagmicrobio.2013.03.025.

Redman JE, Shaw MJ, Mallet AI, Santos AL, Roberts CA, Gernaey AM, Minnikin DE. (2009) Mycocerosic acid biomarkers for the diagnosis of tuberculosis in the Coimbra skeletal collection. Tuberculosis. 89(4): 267-277. DOI: 10.1016/j.tube.2009.04.001.

Reis AC, Albuquerque T, Botelho A, Cunha MV. (2020) Polyclonal infection as a new scenario in Mycobacterium caprae epidemiology. Vet Microbiol. 240: 108533. DOI: 10.1016/j.vetmic.2019.108533.

Riojas MA, McGough KJ, Rider-Riojas C, Rastogi N \& Hazbón MH. (2018) Phylogenomic analysis of the species of the Mycobacterium tuberculosis complex demonstrates that Mycobacterium africanum, Mycobacterium bovis, Mycobacterium caprae, Mycobacterium 
microti and Mycobacterium pinnipedii are later heterotypic synonyms of Mycobacterium tuberculosis. Int J Syst Evol Microbiol. 68(1): 324-332. DOI: 10.1099/ijsem.0.002507.

Roberts C (2020) Fashionable but debilitating diseases: Tuberculosis past and present. In: Purposeful pain: The bioarchaeology of Intentional suffering. Sheridan SG, Gregoricka LA (eds) Springer Nature Switzerland AG, Cham, Switzerland. 21-38.

Roberts CA, Buikstra JE. (2003) The white plague continues. In: Roberts CA, Buikstra JE (eds) The bioarchaeology of tuberculosis: a global view on a reemerging disease. University Press of Florida: Gainesville, FL, USA. 262-272.

Roberts CA, Lucy D, Manchester K. (1994) Inflammatory lesions of ribs: an analysis of the Terry Collection. Am J Phys Anthropol. 95(2): 169-182. DOI: 10.1002/ajpa.1330950205.

Rock RB, Olin M, Baker CA, Molitor TW, Peterson PK. (2008) Central Nervous System Tuberculosis: Pathogenesis and Clinical Aspects. Clin Microbiol Rev. 21(2): 243-261. DOI: 10.1128/CMR.00042-07.

Rodriguez-Takeuchi SK, Renjifo ME, Medina FJ. (2019) Extrapulmonary Tuberculosis: Pathophysiology and Imaging Findings. RadioGraphics. 39(7): 2023-2037. DOI: 10.1148/rg.2019190109.

Roe WD, Lenting B, Kokosinska A, Hunter S, Duignan PJ, Gartrell B, Rogers L, Collins DM, de Lisle GW, Gedye K, Price-Carter M. (2019) Pathology and molecular epidemiology of Mycobacterium pinnipedii tuberculosis in native New Zealand marine mammals. PLoS ONE 14(2): e0212363. DOI: 10.1371/journal.pone.0212363.

Rothschild BM, Martin LD, Lev G, Bercovier H, Kahila Bar-Dal G, Greenblatt C, Donoghue H, Spigelman M, Brittain D. (2001) Mycobacterium tuberculosis complex DNA from an extinct bison dated 17,000 years before the present. Clin Infec. Dis. 33: 305-311.

Rousseau C, Winter N, Pivert E, Bordat Y, Neyrolles O, Avé P, Huerre M, Gicquel B, Jackson M. (2004) Production of phthiocerol dimycocerosates protects Mycobacterium tuberculosis from the cidal activity of reactive nitrogen intermediates produced by macrophages and modulates the early immune response to infection. Cell Microbiol. 6(3): 277-287. DOI: 10.1111/j.1462-5822.2004.00368.x. 
Roy S, Ly D, Li N-S, Altman JD, Piccirilli JA, Moody DB, Adams EJ. (2014) Molecular basis of mycobacterial lipid antigen presentation by CD1c and its recognition by $\alpha \beta \mathrm{T}$ cells. PNAS. 111(43): E4648-E4657. DOI: 10.1073/pnas.1408549111.

Saini NK, Baena A, Ng TW, Venkataswamy MM, Kennedy SC, Kunnath-Velayudhan S, Carreño LJ, Xu J, Chan J, Larsen MH, (...), Porcelli SA. (2016) Suppression of autophagy and antigen presentation by Mycobacterium tuberculosis PE_PGRS47. Nat Microbiol. 1(9): 16133. DOI: 10.1038/nmicrobiol.2016.133.

Salo WL, Aufderheide AC, Buikstra J, Holcomb TA. (1994) Identification of Mycobacterium tuberculosis DNA in a pre-Columbian Peruvian mummy. Proc Natl Acad Sci. 91: 2091-2094.

Santos AL, Roberts CA. (2001) A picture of tuberculosis in young Portuguese people in the early 20th century: a multidisciplinary study of the skeletal and historical evidence. Am $\mathbf{J}$ Phys Anthropol. 115(1): 38-49. DOI: 10.1002/ajpa.1054

Santos AL, Roberts CA. (2006) Anatomy of a serial killer: differential diagnosis of tuberculosis based on rib lesions of adult individuals from the Coimbra Identified Skeletal Collection, Portugal. Am J Phys Anthropol. 130(1): 38-49. DOI: 10.1002/ajpa.20160.

Schultz M, Schmidt-Schultz TH. (2015) Is it possible to diagnose TB in ancient bone using microscopy?. Tuberculosis. 95(Suppl. 1): S80-S86. DOI: 10.1016/j.tube.2015.02.035.

Schultz M. (1993) Spuren unspezifischer Entzündungen an prähistorischen und historischen Schädeln. Ein Beitrag zur Paläopathologie. Anthropologisches Forschungsinstitut: Aesch, Switzerland \& Anthropologische Gesellschaft: Basel, Switzerland.

Schultz M. (1999) The role of tuberculosis in infancy and childhood in prehistoric and historic populations. In Tuberculosis: past and present, Pálfi Gy, Dutour O, Deák J, Hutás I. (eds) TB Foundation: Szeged, Hungary \& Golden Book Publisher: Budapest, Hungary; 503 507.

Schultz M. (2001) Paleohistopathology of bone: a new approach to the study of ancient diseases. Am J Phys Anthropol. 116(Suppl. 33): 106-147. DOI: 10.1002/ajpa.10024.

Schultz M. (2003) Light microscopic analysis in skeletal paleopathology. In Identification of pathological conditions in human skeletal remains, Ortner DJ (ed.). Academic Press: San Diego, CA, USA. 73-107. DOI: 10.1016/B978-012528628-2/50043-0. 
Serrano-Coll H, Salazar-Peláez L, Acevedo-Saenz L, Cardona-Castro N. (2018) Mycobacterium leprae-induced nerve damage: direct and indirect mechanisms. Pathog Dis. 76(6): fty062. DOI: 10.1093/femspd/fty062.

Sevilla IA, Arnal MC, Fuertes M, Martín E, Comenge J, Elguezabal N, de Luco DF, Garrido JM. (2020) Tuberculosis outbreak caused by Mycobacterium caprae in a rabbit farm in Spain. Transbound Emerg Dis. 67(1): 431-441. DOI: 10.1111/tbed.13366.

Shui G, Bendt AK, Jappar IA, Lim HM, Laneelle M, Hervé M, Via LE, Chua GH, Bratschi MW, Rahim SZZ, (...), Wenk MR. (2012) Mycolic acids as diagnostic markers for tuberculosis case detection in humans and drug efficacy in mice. EMBO Mol Med. 4: $27-$ 37. DOI 10.1002/emmm.201100185.

Smith N. (1960) The 'Dassie’ bacillus. Tubercle. 41:203-212.

Song SH, Park KU, Lee JH, Kim EC, Kim JQ, Song J. (2009) Electrospray ionisationtandem mass spectrometry analysis of the mycolic acid profiles for the identification of common clinical isolates of mycobacterial species. J Microbiol Methods. 77(2): 165-177. DOI: 10.1016/j.mimet.2009.01.023.

Spekker O, Hunt DR, Paja L, Molnár E, Pálfi G, Schultz M. (2020a) Tracking down the White Plague: The skeletal evidence of tuberculous meningitis in the Robert J. Terry Anatomical Skeletal Collection. PLoS ONE. 15(3): e0230418. DOI: 10.1371/journal.pone.0230418.

Spekker O, Hunt DR, Váradi OA, Berthon W, Molnár E, Pálfi Gy. (2018) Rare manifestations of spinal tuberculosis in the Robert J. Terry Anatomical Skeletal Collection (National Museum of Natural History, Smithsonian Institution, Washington, DC, USA). Int J Osteoarchaeol. 28: 343-353. DOI: 10.1002/oa.2658.

Spekker O, Pálfi Gy, Kozocsay G, Pósa A, Bereczki Zs, Molnár E. (2012) New cases of probable skeletal tuberculosis from the Neolithic period of Hungary - A morphological study. Acta Biologica Szegediensis 56(2): 115-123.

Spekker O, Schultz M, Paja L, Váradi OA, Molnár E, Pálfi G, Hunt DR. (2020b) Tracking down the White Plague. Chapter two: The role of endocranial abnormal blood vessel impressions and periosteal appositions in the paleopathological diagnosis of tuberculous meningitis. PLoS ONE. 15(9): e0238444. DOI: 10.1371/journal.pone.0238444. 
Spekker O. (2018) Evaulation of endocranial bony changes in relation to tuberculosis in the Robert J. Terry Anatomical Skeletal Collection (Washington, DC, USA). Ph.D. Thesis, University of Szeged, Faculty of Science and Informatics, Szeged, Hungary.

Spigelman M, Lemma E. (1993) The use of the polymerase chain reaction (PCR) to detect Mycobacterium tuberculosis in ancient skeletons. Int J Osteoarchaeol. 3(2):137-143. DOI: 10.1002/oa.1390030211.

Spigelman M; Donoghue HD. (2003) Palaeobacteriology with special reference to pathogenic bacteria. In Emerging Pathogens: The Archaeology, Ecology, and Evolution of Infectious Disease; Greenblatt, C.L., Spigelman, M., Eds.; Oxford University Press Inc.: New York, NY, USA. 175-188.

Sreevatsan S, Pan X, Stockbauer KE, Conell ND, Kreiswirth BN, Whittam TS, Musser JM. (1997) Restricted structural gene polymorphism in the Mycobacterium tuberculosis complex indicates evolutionarily recent global dissemination. PNAS. 94(18): 9869-9874. DOI: 10.1073/pnas.94.18.9869.

Stucki D, Brites D, Jeljeli L, Coscolla M, Liu Q, Trauner A, Fenner L, Rutaihwa L, Borrell S, Luo T, Gao Q, Kato-Maeda M, Ballif M, Egger M, Macedo R, (...), Gagneux S. (2016) Mycobacterium tuberculosis lineage 4 comprises globally distributed and geographically restricted sublineages. Nat Genet. 48(12):1535-1543. DOI: 10.1038/ng.3704.

Supply P, Brosch R. (2017) The Biology and Epidemiology of Mycobacterium canettii. In: Gagneux S. (eds) Strain Variation in the Mycobacterium tuberculosis Complex: Its Role in Biology, Epidemiology and Control. Advances in Experimental Medicine and Biology, vol 1019. Springer, Cham. DOI: 10.1007/978-3-319-64371-7_2

Supply P, Marceau M, Mangenot S, Roche D, Rouanet C, Khanna V, Majlessi L, Criscuolo A, Tap J, Pawlik A, (...), Brosch R. (2013) Genomic analysis of smooth tubercle bacilli provides insights into ancestry and pathoadaptation of Mycobacterium tuberculosis. Nat Genet. 45: 172-179. DOI: 10.1038/ng.2517.

Szewczyk R, Kowalsky K, Janiszewska-Drobinska B, Druszczyńska M. (2013) Rapid method for Mycobacterium tuberculosis identification using electrospray ionization tandem mass spectrometry analysis of mycolic acids. Diagnostic Microbiology and Infectious Disease. 76: 298-305. DOI: 10.1016/j.diagmicrobio.2013.03.025. 
Szikossy I, Bernert Zs, Pap I. (1997) Anthropological investigation of the 18th-19th century ossuary of the Dominican Church, Vác, Hungary. Acta Biol Szeged. 42: 145-50.

Takayama K, Wang C, Besra GS. (2005) Pathway to synthesis and processing of mycolic acids in Mycobacterium tuberculosis. Clin Microbiol Rev. 18(1): 81-101. DOI: 10.1128/CMR.18.1.81-101.2005.

Taylor GM, Goyal M, Legge AJ, Shaw RJ, Young D. (1999) Genotypic analysis of Mycobacterium tuberculosis from medieval human remains. Microbiology. 145: 899-904.

Taylor GM, Young DB, Mays SA. (2005) Genotypic analysis of the earliest known prehistoric case of tuberculosis in Britain. J. Clin. Microbiol. 45: 2236-2240.

Teramoto K, Suga M, Sato T, Wada T, Yamamoto A, Fujiwara N. (2015) Characterization of mycolic acids in total fatty acid methyl ester fractions from Mycobacterium species by high resolution MALDI-TOFMS. Mass Spectrom. 4(1): A0035. DOI: 10.5702/massspectrometry.A0035.

Tessema B, Beer J, Merker M, Emmrich F, Sack U, Rodloff AC, Niemann S. (2013) Molecular epidemiology and transmission dynamics of Mycobacterium tuberculosis in Northwest Ethiopia: new phylogenetic lineages found in Northwest Ethiopia. BMC Infect Dis. 13: 13.1 DOI: 10.1186/1471-2334-13-131.

Thapa J, Paudel S, Sadaula A, Shah Y, Maharjan B, Kaufman GE, McCauley D, Gairhe KP, Tsubota T, Suzuki Y, Nakajima C. (2016) Mycobacterium orygis-Associated Tuberculosis in Free-Ranging Rhinoceros, Nepal, Emerg Infect Dis. 22(3): 570-572. DOI: 10.3201/eid2203.151929.

Thorel MF. (1980) Isolation of Mycobacterium africanum from monkeys. Tubercle. 61: 101104.

Tobian AAR, Potter NS, Ramachandra L, Pai RK, Convery M, Boom WH, Harding CV. (2003) Alternate Class I MHC Antigen Processing Is Inhibited by Toll-Like Receptor Signaling Pathogen-Associated Molecular Patterns: Mycobacterium tuberculosis 19-kDa Lipoprotein, CpG DNA, and Lipopolysaccharide. J Immunol. 171: 1413-1422. DOI: 10.4049/jimmunol.171.3.1413.

Tortoli E. (2014) Microbiological features and clinical relevance of new species of the genus Mycobacterium. Clin Microbiol Rev. 27(4): 727-752. DOI: 10.1128/CMR.00035-14. 
Turenne CY (2019) Nontuberculous mycobacteria: Insights on taxonomy and evolution. Infect Genet Evol. 72: 159-168. DOI: 10.1016/j.meegid.2019.01.017.

van Ingen J, Rahim Z, Mulder A, Boeree MJ, Simeone R, Brosch R \& van Soolingen D. (2012) Characterization of Mycobacterium orygis as M. tuberculosis Complex Subspecies. Emerg Infect Dis. 18(4): 653-655. DOI: 10.3201/eid1804.110888.

van Ingen J, Turenne CY, Tortoli E, Wallace RJ, Brown-Eliott BA. (2018) A definition of the Mycobacterium avium complex for taxonomical and clinical purposes, a review. Int $\mathbf{J}$ Syst Evol Microbiol. 68: 3666-3677. DOI: 10.1099/ijesm.0.003026.

Váradi OA, Rakk D, Spekker O, Terhes G, Urbán E, Berthon W, Pap I, Szikossy I, Maixner F, Zink A, Vágvölgyi Cs, Donoghue HD, Minnikin DE, Szekeres A, Pálfi Gy. (2020) Verification of tuberculosis infection among Vác mummies (18th century CE, Hungary) based on lipid biomarker profiling with a new HPLC-HESI-MS approach. Tuberculosis. Accepted, in press

Velasco-Velázquez MA, Barrera D, González-Arenas A, Rosales C, Agramonte-Hevia J. (2003) Macrophage - Mycobacterium tuberculosis interactions: role of complement receptor 3. Microb Pathog. 35(3): 125-131. DOI: 10.1016/s0882-4010(03)00099-8.

Vinnard C, Macgregor RR. (2009) Tuberculous meningitis in HIV-infected individuals. Current HIV/AIDS Reports. 6(3): 139-145.

Vuorinen HS. (1999) The tuberculosis epidemic in Finland from the $18^{\text {th }}$ to the $20^{\text {th }}$ century. Pálfi Gy, Dutour O, Deák J, Hutás I. (eds) Tuberculosis past and present. TB Foundation: Szeged, Hungary \& Golden Book Publisher: Budapest, Hungary. 105-112.

Wagner JC, Buchanan G, Bokkenheuser V, Leviseur S. (1958) An acid-fast bacillus isolated from the lungs of the Cape hyrax, Procavia capensis (Pallas). Nature. 181(4604): 284-285. DOI: $10.1038 / 181284 b 0$.

Wang J, McIntosh F, Radomski N, Dewar K, Simeone R, Enninga J, Brosch R, Rocha EP, Veyrier FJ, Behr MA. (2015a) Insights on the Emergence of Mycobacterium tuberculosis from the Analysis of Mycobacterium kansasii. Genome Biol Evol. 7(3): 856-870. DOI: 10.1093/gbe/evv035.

Wang C, Wang M, Han X. (2015b) Applications of mass spectrometry for cellular lipid analysis. Mol BioSyst. 11: 698-713. DOI: 10.1039/C4MB00586D. 
Watanabe M, Aoyagi Y, Ridell M, Minnikin DE. (2001) Separation and characterization of individual mycolic acids in representative mycobacteria. Microbiology. 147: 1825-1837.

Willmann J, Thiele H, Leibfritz D. (2011) Combined reversed phase HPLC, mass spectrometry, and NMR spectroscopy for a fast separation and efficient identification of phosphatidylcholines. J Biomed Biotechnol. 2011:385786. DOI: 10.1155/2011/385786.

World Health Organization. (2020) TB disease burden. In: Global tuberculosis report 2020. WHO: Geneva, Italy; 23-70

Yoshida S, Suga S, Ishikawa S, Mukai Y, Tsuyuguchi K, Inoue Y, Yamamoto T, Wada T. (2018) Mycobacterium caprae infection in captive Borneo elephant, Japan. Emerg Infect Dis. 24(10): 1937-1940. DOI: 10.3201/eid2410.180018.

Yoshino T, Miyazaki J, Kojima T, Kandori S, Shiga M, Kawahara T, Kimura T, Naka T, Kiyohara H, Watanabe M, (...), Nishiyama H. (2019) Cationized liposomal keto-mycolic acids isolated from Mycobacterium bovis bacillus Calmette-Guérin induce antitumor immunity on a syngeneic murine bladder cancer model. Plos One 14(1): e0209196. DOI: 10.1371/journal.pone.0209196.

Yunker LP, Stoddard RL, McIndoe JS. (2014) Practical approaches to the ESI-MS analysis of catalytic reactions. J Mass Spectrom. 49(1): 1-8. DOI: 10.1002/jms.3303.

Zhu C, Lipp JS, Wörmer L, Becker KW, Schröder J, Hinrichs KU. (2013) Comprehensive glycerol ether lipid fingerprints through a novel reversed phase liquid chromatography-mass spectrometry protocol. Org Geochem. 65:53-62. DOI: 10.1016/j.orggeochem.2013.09.012. Zhu J, Cole RB. (2000) Formation and Decompositions of Chloride Adduct Ions, $[\mathrm{M}+\mathrm{Cl}]^{-}$ in Negative Ion Electrospray Ionization Mass Spectrometry. J Am Soc Mass Spectrom. 11: 932-941

Zink A, Haas CJ, Reischl U, Szeimies U, Nerlich AG. (2001) Molecular analysis of skeletal tuberculosis in an ancient Egyptian population. J Med Microbiol 50: 355-366.

Zink AR, Sola C, Reischl U, Grabner W, Rastogi N, Wolf H \& Nerlich AG. (2003) Characterization of Mycobacterium tuberculosis Complex DNAs from Egyptian Mummies by Spoligotyping. J Clin Microbiol. 41(1): 359-367. DOI: 10.1128/JCM.41.1.359367.2003 . 
Zmak L, Obrovac M, Jankovic Makek M, Perko G, Trkanjec J. (2019) From Peruvian mummies to living humans: first case of pulmonary tuberculosis caused by Mycobacterium pinnipedii. Int J Tuberc Lung Dis. 23(12): 1283-1285. DOI: 10.5588/ijtld.19.0159.

\section{LIST OF PUBLICATIONS}

MTMT ID: 10053024

\subsection{THE 2 PAPERS PROVIDING BASIS FOR THE DISSERTATION}

Váradi OA, Rakk D, Spekker O, Terhes G, Urbán E, Berthon W, Pap I, Szikossy I, Maixner F, Zink A, Vágvölgyi Cs, Donoghue HD, Minnikin DE, Szekeres A, Pálfi Gy. (2020) Verification of tuberculosis infection among Vác mummies (18th century CE, Hungary) based on lipid biomarker profiling with a new HPLC-HESI-MS approach. Tuberculosis. Accepted, in press. IF 2019: 2.576

Spekker O, Schultz M, Paja L, Váradi OA, Molnár E, Pálfi Gy, Hunt DR. (2020) Tracking down the White Plague. Chapter two: The role of endocranial abnormal blood vessel impressions and periosteal appositions in the paleopathological diagnosis of tuberculous meningitis. PLOS ONE. 15(9): e0238444. DOI: 10.1371/journal.pone.0238444. IF2019: 2,740

\subsection{PEER-REVIEWED JOURNAL ARTICLES-}

Váradi OA, Horváth O, Marcsik A, Molnár E, Pálfi Gy, Bereczki Zs. (2015) Különleges formájú jelképes trepanációk a Dél-Alföldröl. Anthropologiai Közlemények. 56: 91-104.

Spekker O, Hunt DR, Váradi OA, Berthon W, Molnár E, Pálfi Gy. 2018. Rare manifestations of spinal tuberculosis in the Robert J. Terry Anatomical Skeletal Collection (National Museum of Natural History, Smithsonian Institution, Washington, DC, USA). International Journal of Osteoarchaeology 28(3): 343-353. DOI: 10.1002/oa.2658. IF 2018: 1.180

Spekker O, Schultz M, Paja L, Váradi OA, Molnár E, Pálfi Gy, Hunt DR. (2020) Tracking down the White Plague. Chapter two: The role of endocranial abnormal blood vessel impressions and periosteal appositions in the paleopathological diagnosis of tuberculous 
meningitis. PLOS ONE. 15(9): e0238444. DOI: 10.1371/journal.pone.0238444. IF2019: 2.740

Tihanyi B, Berthon W, Kis L, Váradi OA, Dutour O, Révész L, Pálfi Gy. (2020) "Brothers in arms": Activity-related skeletal changes observed on the humerus of individuals buried with and without weapons from the 10th-century CE Carpathian Basin. International Journal of Osteoarchaeology. DOI: 10.1002/oa.2910. IF2019: 1.228

Váradi OA, Rakk D, Spekker O, Terhes G, Urbán E, Berthon W, Pap I, Szikossy I, Maixner F, Zink A, Vágvölgyi Cs, Donoghue HD, Minnikin DE, Szekeres A, Pálfi Gy. (2020) Verification of tuberculosis infection among Vác mummies (18th century CE, Hungary) based on lipid biomarker profiling with a new HPLC-HESI-MS approach. Tuberculosis. Accepted, in press. $\mathbf{I F}_{2019} \mathbf{2 . 5 7 6}$

TOTAL IF: $\mathbf{7 . 7 2 4}$

\subsection{PAPERS PUBLISHED IN CONFERENCE PROCEEDINGS}

Bereczki Zs, Váradi OA, Molnár E, Marcsik A, Medgyesi P, Pálfi Gy. (2016) Possible signs of ritual healing observed in the 7-8th c. AD Avar Age site of Császárszállás-Hanzély tanya (MRT 10. 385. 4/21. LH.). In: Gál SzS (ed.): The Talking Dead. New Results from Central and Eastern European Osteoarchaeology. Proceedings of the First International Conference of the Török Aurél Anthropological Association from Târgu Mureş. Mega Publishing House. Cluj-Napoca, Romania. 19-27.

Váradi OA, Kecskeméti A, Spekker O, Molnár E, Bereczki Zs, Szekeres A, Vágvölgyi Cs, Pálfi Gy. (2016) Cases of tuberculosis infection verified by lipid biomarker analysis in Hungarian archaeological samples. In: Gál SzS (ed.): The Talking Dead. New Results from Central and Eastern European Osteoarchaeology. Proceedings of the First International Conference of the Török Aurél Anthropological Association from Târgu Mureş. Mega Publishing House. Cluj-Napoca, Romania. 129-142.

Spekker O, Hunt DR, Paja L, Váradi OA, Molnár E, Pálfi Gy. (2018) Endocranial bony changes probably related to tuberculous meningitis - Example cases from the Robert J. Terry Anatomical Skeletal Collection (Washington, DC, USA). In: Gál SzS (ed.): The Talking Dead 2. Past and Present of Biological Anthropology. The Heritage of Török Aurél's Oeuvre. New Results from Ancient Tuberculosis and Leprosy Research. Proceedings of the 
Second International Conference of the Török Aurél Anthropological Association from Târgu Mureş. Mega Publishing House. Cluj-Napoca, Romania. 81-90.

Váradi OA, Rakk D, Spekker O, Terhes G, Urbán E, Bereczki Zs, Vágvölgyi Cs, Pálfi Gy, Szekeres A. (2018) Differentiation between Mycobacterium tuberculosis and the nontuberculous Mycobacterium gordonae via high resolution mass spectrometric technique. In: Gál SzS (ed.): The Talking Dead 2. Past and Present of Biological Anthropology. The Heritage of Török Aurél's Oeuvre. New Results from Ancient Tuberculosis and Leprosy Research. Proceedings of the Second International Conference of the Török Aurél Anthropological Association from Târgu Mureş. Mega Publishing House. Cluj-Napoca, Romania. 137-143.

\subsection{CONFERENCE PRESENTATIONS}

\subsubsection{National conferences}

Szuhaj M, Váradi OA, Rákhely G, Kovács LK, Bagi Z. (2015) Utilization of hydrogen in mesophilic biogas fermentors. In MTA SZBK Straub-Napok (Szeged, Hungary, 3-4 June 2015). MTA SZBK, Szeged, Hungary.

Tihanyi B, Balázs J, Berthon W, Király K, Kis L, Spekker O, Váradi OA, Bereczki Zs, Molnár E, Marcsik A, Pálfi Gy. (2019) Az SZTE Embertani Tanszék kutatásai az “Árpádkori magyarság embertani-genetikai képe" címü projekt keretében. In: A Magyar Biológiai Társaság Embertani Szakosztályának 398. Szakülése (Szeged, Hungary, 9 October 2019). Department of Biological Anthropology, University of Szeged: Szeged, Hungary.

\subsubsection{International conferences}

Bagi Z, Szuhaj M, Váradi OA, Ács N, Rákhely G, Kovács LK. (2014) The relationship between hydrogen metabolism and biogas production, regulation mechanisms. In: Conference Proceedings for the International Scientific Conference Biogas Science 2014: International Conference on Anaerobic Digestion (Vienna, Austria, 26-30 October 2014). University of Natural Resources and Life Siences, Vienna, Austria; 144-145.

Váradi OA, Horváth O, Bereczki Zs. (2014) Szilvamag alakú jelképes trepanációk a Kárpátmedencében. In: $13^{\text {th }}$ International Conference on Applications of Natural, Technological and Economic Sciences (Szombathely, Hungary, 17 May 2014). Abstracts of the Presentations. Nyugat-magyarországi Egyetem, Szombathely, Hungary. 25. 
Bereczki Zs, Váradi OA, Horváth O, Marcsik A, Molnár E, Pálfi Gy. (2015) Healing and sexual symbolism - Avar trephinations in the 7-9th century AD Carpathian basin. In: $11^{\text {th }}$ Meeting of the Society for Anthropology (GfA). Evolutionary and Modern Challenges to Homo sapiens - An Anthropological Inquiry (Munich, Germany, 15-18 September 2015). Abstract and Program Booklet. Munich, Germany. 15.

Spekker O, Lovász G, Masson M, Pósa A, Mészáros K, Váradi OA, Neparáczki E, Maczel M, Marcsik A, Schultz M, Nerlich A, Minnikin DE, Donoghue HD, Maixner F, Zink A, Dutour O, Paja L, Bereczki Zs, Molnár E, Pálfi Gy. (2015) On the traces of ancient tuberculosis: a preliminary summary of the tuberculosis paleopathology research in the Szeged Anthropological Collection from the 1970's to the present day. In: $11^{\text {th }}$ Meeting of the Society for Anthropology (GfA). Evolutionary and Modern Challenges to Homo sapiens - An Anthropological Inquiry (Munich, Germany, 15-18 September 2015). Abstract and Program Booklet. Munich, Germany. 100-101.

Váradi OA, Tihanyi B, Horváth O, Marcsik A, Molnár E, Pálfi Gy, Bereczki Zs. (2015) Symbolic trephinations of extraordinary shape in the Carpathian Basin. In: $1^{\text {st }}$ Conference of the Anthropological Association „Aurél Török” (Târgu Mureș, Romania, 13-15 November 2015). Târgu Mureș, Romania. 4.

Spekker O, Molnár E, Lovász G, Marcsik A, Masson M, Bereczki Zs, Paja L, Balázs J, Váradi OA, Neparáczki E, Pósa A, Maixner F, Zink A, Perrin P, Coqueugniot H, Dutour O, Pálfi Gy. (2016) Paléopathologie infectieuse chez des sujets immatures: exemple de la tuberculose. Résultats de 45 ans de recherche effectuée dans la collection anthropologique de Szeged. In: Groupe des Paleopathologistes de Langue Française. Colloque 2016 (Toulouse, France, 11-12 March 2016). Programme and Volume des Résumés. Faculté de medicine Purpan, Université de Paul Sabatier Toulouse, Toulouse, France. 19.

Spekker O, Molnár E, Marcsik A, Lovász G, Masson M, Maczel M, Pósa A, Neparáczki E, Váradi OA, Schultz M, Nerlich A, Minnikin DE, Donoghue HD, Maixner F, Zink A, Dutour O, Bereczki Zs, Paja L, Pálfi Gy. (2016) On the traces of ancient tuberculosis: possibilities of the macromorphological diagnosis of tuberculosis in prehistoric and historic osteological series - Skeletal tuberculosis cases from the Szeged Anthropological Collection. In: Working Your Fingers to the Bone - An Interdisciplinary Conference on Identifying Occupation from the Skeleton (Coimbra, Portugal, 6-8 July 2016). Program and Abstract Book. Department of Life Sciences, University of Coimbra, Coimbra, Portugal. 46. 
Váradi OA, Kecskeméti A, Spekker O, Molnár E, Bereczki Zs, Szekeres A, Vágvölgyi Cs, Pálfi Gy. (2016) Mycobacterium tuberculosis komplex kimutatása lipid biomarkerek segítségével. In: $15^{\text {th }}$ International Conference on Applications of Natural, Technological and Economic Sciences (Szombathely, Hungary, 14 May 2016). Abstracts of the Presentations. Nyugat-magyarországi Egyetem, Szombathely, Hungary. 28.

Bereczki Zs, Váradi OA, Király K, Tóth N, Bukva M, Tihanyi B, Molnár E, Pálfi Gy. (2017) New cases of ritualistic cranial interventions from Hungary. In: $2^{\text {nd }}$ Conference of the 'Török Aurél' Anthropological Association. Past and Present of Biological Anthropology. The Heritage of Török Aurél's Oeuvre (Târgu Mureş, Romania, 13-15 October 2017). Program and Abstracts. Târgu Mureş, Romania. 17-18.

Váradi OA, Rakk D, Kecskeméti A, Bereczki Zs, Urbán E, Terhes G, Vágvölgyi Cs, Szekeres A, Pálfi Gy. (2017) Mycobacterium tuberculosis komplex okozta fertőzés kimutatása ásatag csontanyagból lipid biomarkerek segítségével. In: $16^{\text {th }}$ International Conference on Applications of Natural, Technological and Economic Sciences (Szombathely, Hungary, 20 May 2017). Abstracts of the Presentations. Nyugatmagyarországi Egyetem, Szombathely, Hungary. 26.

Váradi OA, Rakk D, Kecskeméti A, Bereczki Zs, Urbán E, Terhes G, Vágvölgyi Cs, Minnikin, DE, Pálfi Gy, Szekeres A. (2017) Detection of ancient TB infection from bones on the base of specific lipid biomarkers. In: $19^{\text {th }}$ Danube-Kris-Mures-Tisa (DKMT) Euroregional Conference on Environment and Health: Program and Abstracts (Szeged, Hungary, 9-10 June 2017). University of Szeged, Szeged, Hungary. 56.

Váradi OA, Rakk D, Kecskeméti A, Bereczki Zs, Urbán E, Terhes G, Vágvölgyi Cs, Szekeres A, Pálfi Gy. (2017) Verification of ancient TB infection cases using specific lipid biomarkers. In: $2^{\text {nd }}$ Conference of the 'Török Aurél' Anthropological Association. Past and Present of Biological Anthropology. The Heritage of Török Aurél's Oeuvre (Târgu Mureş, Romania, 13-15 October 2017). Program and Abstracts. Târgu Mureş, Romania. 11-12.

Spekker O, Hunt DR, Váradi OA, Berthon W, Pálfi Gy, Molnár E. 2018. Rare manifestations of spinal tuberculosis in the Robert J. Terry Anatomical Skeletal Collection (National Museum of Natural History, Smithsonian Institution, Washington, DC, USA). In $22^{\text {nd }}$ European Meeting of the Paleopathology Association (Zagreb, Croatia, 28 August-1 September 2018). Book of Abstracts. Institute for Anthropological Research: Zagreb, Croatia; 59-60. 
Király K, Váradi OA, Elekes G, Bukva M, Pintér Z, Molnár E, Pálfi Gy, Bereczki Zs. (2019) Clarifying the indication of surgical trepanations using statistical analysis. In: $3^{\text {rd }}$ Conference of the 'Török Aurél' Anthropological Association. Ancient Humans, Ancient Diseases in Central and Eastern Europe (Târgu Mureş, Romania, 11-13 October 2019). Program and Abstracts. Târgu Mureş, Romania. 29-30.

Molnár E, Hegyi A, Bereczki Zs, Pálfi Gy, Kis L, Váradi OA, Spekker O. (2019) An astonishing case of skeletal TB from the Árpádian Age cemetery of Györszentiván (GyőrMoson-Sopron county, Hungary. In: $3^{\text {rd }}$ Conference of the 'Török Aurél' Anthropological Association. Ancient Humans, Ancient Diseases in Central and Eastern Europe (Târgu Mureş, Romania, 11-13 October 2019). Program and Abstracts. Târgu Mureş, Romania. $27-28$.

Pap I, Szikossy I, Váradi OA, Szekeres A, Bereczki Zs, Karlinger K, Pölöskei G, Csukovits A, Szvák E, Spigelman M, Donoghue HD, Maixner F, Zink A, Pálfi Gy. (2019) Pathological alterations caused by gout of an 18th century TB infected woman from the Vác Mummy Collection, Hungary. In: $3^{\text {rd }}$ Conference of the 'Török Aurél' Anthropological Association. Ancient Humans, Ancient Diseases in Central and Eastern Europe (Târgu Mureş, Romania, 11-13 October 2019). Program and Abstracts. Târgu Mureş, Romania. 21-22.

Pálfi Gy, Szikossy I, Váradi OA, Karlinger K, Maixner F, Pap I. (2019) Multidisciplinary study of an 18th century mummy (Vác, Hungary) - A possible TB-syphilis co-infection and other profession related changes. In: $3^{\text {rd }}$ Conference of the 'Török Aurél' Anthropological Association. Ancient Humans, Ancient Diseases in Central and Eastern Europe (Târgu Mureş, Romania, 11-13 October 2019). Program and Abstracts. Târgu Mureş, Romania. 20 .

Váradi OA, Rakk D, Kecskeméti A, Terhes G, Spekker O, Vágvölgyi Cs, Szekeres A, Pálfi Gy. (2019) Optimization of lipid biomarker analysis revealing the ancient TB infections. In: $3^{\text {rd }}$ Conference of the 'Török Aurél' Anthropological Association. Ancient Humans, Ancient Diseases in Central and Eastern Europe (Târgu Mureş, Romania, 11-13 October 2019). Program and Abstracts. Târgu Mureş, Romania. 25-26. 